\title{
Com a palavra... Os profissionais da educação: Relatos de experiência sobre 0 trabalho educacional
}

Organizadora:

Fernanda Oliveira Costa Gomes 


\section{CONSELHO EDITORIAL}

\section{Comitê Editorial}

Editora-Chefe: Professora Doutora Andrezza M. B. do N. Tavares Editor Adjunto: Professor Doutor Fábio Alexandre Araújo dos Santos

Diagramação e Projeto Gráfico: Alexsandra Santana dos Santos

Normalização: Miqueias Alex de Souza Pereira

Revisão de Textos: Professor Doutor Dayvyd Lavaniery Marques de Medeiros

Arte e Capa: Eddean Riquemberg C. Xavie

\section{Conselho Editorial Internacional}

Presidente: Professor Doutor Manuel Tavares

Professor Doutor Bento Duarte da Silva

Professor Doutor Dionísio Luís Tumbo

Professor Doutor Gabriel Linari

Professora Doutora Cristina Rafaela Riccí

Professor Gustavo Adólfo Fernández Díaz

Professor Manuel Teixeira

Professora Doutora Antonia Dalva França Carvalho

Professora Doutora Elda Silva do Nascimento Melo

Professora Doutora Karla Cristina Silva Sousa

Professora Doutora Márcia Adelino da Silva Dias

Professor Doutor Adir Luiz Ferreira

Professora Doutora Giovana Carla Cardoso Amorim

Professora Doutora Lucila Maria Pesce de Oliveira

\section{Comitê Científico Da Área De Ciências Humanas}

Presidente: Professora Doutora Juliana Alencar de Souza

Professor Doutor Júlio Ribeiro Soares

Professora Doutora Leila Salim Leal

Professora Doutora Christiane Mylena Tavares de Menezes Professor Doutor José Rodolfo Lopes de Paiva Cavalcanti Professora Doutora Kadydja Karla Nascimento Chagas

Professor Doutor Avelino de Lima Neto

Professor Doutor Sérgio Luiz Bezerra Trindade

Professor Doutor Eduardo Henrique Cunha de Farias

Professor Doutor Bruno Lustosa de Moura

Professora Doutora Maria da Conceição Monteiro Cavalcanti

Professor Doutor José Moisés Nunes da Silva Moura

Professora Doutora Francinaide de Lima Silva Nascimento Moura

Professor Doutor José Paulino Filho

Professor Doutor Marcos Torres Carneiro

Professora Maria Judivanda da Cunha

Professor João Maria de Lima

Professor Eric Mateus Soares Dias

Professor Adriel Felipe de Araújo Bezerra

Professor Luiz Antonio da Silva dos Santos

Professora Rayssa Cyntia Baracho Lopes Souza

Professora Valdete Batista do Nascimento

Professor Bernardino Galdino de Sena Neto

Professora Wendella Sara Costa da Silva
(Instituto Federal de Ciência e Tecnologia do Rio Grande do Norte - Brasil) (Instituto Federal de Ciência e Tecnologia do Rio Grande do Norte - Brasil)

(Instituto Federal de Ciência e Tecnologia do Rio Grande do Norte - História) (Centro Universitário do Rio Grande do Norte - Biologia)

(Instituto Federal de Ciência e Tecnologia do Rio Grande do Norte - Física) (Instituto Federal de Educação Ciência e Tecnologia da Paraíba - Administração) (Instituto Federal de Ciência e Tecnologia do Rio Grande do Norte - Matemática) (Instituto Federal de Ciência e Tecnologia do Rio Grande do Norte - Educação) (Instituto de Educação Superior Presidente Kennedy - Matemática) (Faculdade Metropolitana Norte Riograndense - Educação) (Faculdade Metropolitana Norte Riograndense - Biologia) (Escola da Assembleia Legislativa do Rio Grande do Norte - Linguística) (Faculdade Metropolitana Norte Riograndense - Gestão Ambiental / Estudos Urbanos) (Faculdade Metropolitana Norte Riograndense - FAMEN - Sociologia / Antropologia)

(Faculdade Metropolitana Norte Riograndense - Educação / Teologia / Informática) (Faculdade do Maciço do Baturité - Educação / Psicopedagogia) (Faculdade Metropolitana Norte Riograndense - Direito / Filosofia) (Faculdade Metropolitana Norte Riograndense - História / Gestão Pública) (Faculdade Metropolitana Norte Riograndense - Geografia) 
FERNANDA OLIVEIRA COSTA GOMES

Organizadora

Com a palavra... os profissionais da educação: relatos de experiência sobre o trabalho educacional

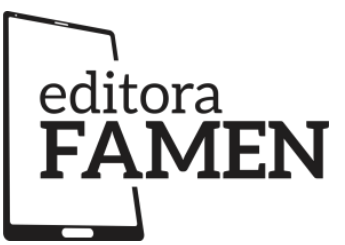


Editora-Chefe: Professora Doutora Andrezza M. B. do N. Tavares, Instituto Federal de Ciência e Tecnologia do Rio Grande do Norte (IFRN). Natal, RN, Brasil.

Editor Adjunto: Professor Doutor Fábio Alexandre Araújo dos Santos, Instituto Federal de Ciência e Tecnologia do Rio Grande do Norte (IFRN). Natal, RN, Brasil.

Diagramação e Projeto Gráfico: Alexsandra Santana dos Santos

Normalização: Miqueias Alex de Souza Pereira

Revisão de Textos: Professor Doutor Dayvyd Lavaniery Marques de Medeiros

Arte e Capa: Eddean Riquemberg C. Xavier

DOI: https://doi.org/10.36470/famen.2021.13

Catalogação da Publicação na fonte

Biblioteca Immanuel Kant

Miqueias Alex de Souza Pereira CRB-15/925

C728

Com a palavra... os profissionais da educação: relatos de experiência sobre o trabalho educacional [E-book] / Fernanda Oliveira Costa Gomes. - Natal, RN: Editora Famen, 2021.

$7,35 \mathrm{~Kb} ; \mathrm{PDF}$

ISBN 978-65-87028-04-0

DOI: https://doi.org/10.36470/famen.2021.13

1. Relatos de experiência. 2. Vida profissional docente. 3. Profissionais da Educação. I. Gomes, Fernanda Oliveira Costa.

CDD 370.1 (1.ed)

CDU 370

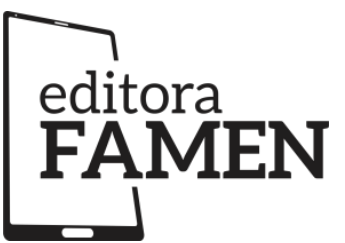




\section{RESUMO}

A presente obra intitulada Com a palavra... os profissionais da educação consiste numa coletânea que apresenta relatos de experiências de profissionais atuantes na área educacional. As ideias presentes nas seções desta coletânea se estruturam a partir das questões problematizadoras: 1) Quais são os desafios e percalços enfrentados por profissionais que trabalham na área da educação na atualidade? 2) O que dizem eles sobre suas vidas profissionais? 3) Quais são os debates teóricos possíveis de se realizar, a partir das experiências vividas nas instituições de ensino? A realização deste trabalho partiu da necessidade de abrir espaço para se ouvir as vozes daqueles que trabalham na área. Partimos de uma compreensão de que existem muitas histórias vividas no ambiente escolar que devem ser conhecidas, e relatadas por aqueles que as viveram. Os artigos em formato de relatos de experiência, apresentados aqui, trazem fatos vividos nas instituições de ensino e a partir de tais relatos desenvolvem uma reflexão cientificamente fundamentada para melhor compreensão sobre o trabalho educacional. Esse trabalho foi construído com a contribuição de um grupo de pessoas que atuam em escolas como professores de educação infantil, ensino fundamental, ensino médio, gestão escolar, coordenação pedagógica e na formação de professores, portanto, temos aqui uma visão de diferentes profissionais em diferentes funções o que enriquece essa obra e amplia nossa percepção sobre o trabalho realizado na educação. Nossa intenção consiste em contribuir, mesmo que modestamente, com os estudos científicos na área da educação, ampliando o léxico de conhecimento sobre a vida na profissão docente e consequentemente contribuindo para a manutenção e defesa de uma educação integral, democrática e que leve nossos alunos a desenvolverem as condições necessárias para escolherem seus caminhos, escrevendo suas histórias na construção de uma sociedade emancipada, justa, livre de preconceitos e livre de desigualdades.

Palavras-chave: Relatos de experiência. Vida profissional docente. Profissionais da Educação. Desafios contemporâneos na educação. 


\begin{abstract}
The present piece, entitled 'With the word... education professionals', consists of a collection that presents reports of the experiences of professionals working in the educational area. The ideas present in the main collections stem from the problematizing questions: 1) What are the challenges and setbacks faced by professionals who work in the field of education? 2) What do they say about their professional lives? 3) What are the possible theoretical debates to be carried out based on the experiences lived in training institutions? The development of this work started from the necessity of opening this space to listen to the voices from those who work in the area. We start from an understanding that there are many stories lived in the school environment that must be reported and brought to light by those who lived them. The articles in format of experience reports presented here, bring facts lived in educational institutions and, from such reports, a scientifically based reflection for a better understanding of educational work was developed. This work was built with the contribution of a group of people who work in schools as teachers for early childhood education, elementary school, high school, school management, pedagogical coordination and teacher training. Therefore, we have here, views of different professionals in different functions which enrich this work and broaden our perception of the work carried out in education. Our intention consists in contributing, even if modestly, with scientific studies in the field of education, expanding the lexicon of knowledge about life in the teaching profession and consequently contributing to the maintenance and defense of an integral, democratic education that leads our students to develop the necessary conditions to choose their paths, writing their stories in the construction of a just, free from prejudice and free from inequalities emancipated society.
\end{abstract}

Keywords: Experience reports. Teaching professional life. Education professionals. Contemporary challenges in education. 


\section{APRESENTAÇÃO}

Ouvir a voz do professor devia ensinar-nos que o autobiográfico, "a vida", é de grande interesse quando os professores falam do seu trabalho. E, a um nível de senso comum, não considero surpreendente, se não francamente injusto, que durante tanto tempo os investigadores tenham considerado as narrativas dos professores como dados irrelevantes (GOODSON, 2013, p. 71).

Esta coletânea apresenta relatos de experiências de profissionais atuantes na área educacional. Nosso objetivo é dar voz a professores, diretores, coordenadores, pessoas que vivenciam cotidianamente a realidade da educação brasileira, ampliando as discussões acerca do trabalho na área educacional a partir das histórias da vida destes profissionais.

Um relato de experiência consiste numa produção textual onde são apresentadas manifestações de um ou mais sujeitos, com a finalidade de expor experiências e práticas vividas numa determinada situação. Os trabalhos científicos no formato de relatos de experiências têm sido cada vez mais utilizados em áreas como: Medicina, Psicologia, Educação, sendo portanto, cada vez mais recorrente em estudos acadêmicos.

A motivação para a elaboração deste trabalho surgiu a partir da percepção de que as experiências vividas por profissionais da educação trazem conhecimentos, discussões e análises importantes para pensar e repensar nossa área de atuação, e muitas vezes tais histórias são subestimadas, ou, naturalizadas a ponto de não serem divulgadas, ou até mesmo, valorizadas.

Os relatos aqui apresentados e teorizados partem de uma tentativa de resistência para colocar em pauta a voz dos professores. Pois, são muitas as vozes que palpitam, opinam, sugestionam, mas são os profissionais atuantes, ou que já atuaram na área, que tem a propriedade para dizer o que acontece cotidianamente na profissão.

Existem muitos saberes, conhecimentos que construímos no exercício do nosso trabalho. Partindo da compreensão de que os relatos de experiência podem auxiliar na compreensão sobre a educação, sobre o ensino, e sobre a própria profissão, organizamos essa coletânea com relatos de professores que cotidianamente trabalham no chão das escolas públicas e particulares, enfrentando os desafios, percalços que se apresentam constantemente nas instituições. Considerando os desafios próprios da profissão surge 
necessidade de dar voz aos professores, conhecer como as políticas educacionais influenciam em suas vidas, conhecer suas histórias, seus aprendizados, conhecer suas dificuldades, mas também compreender suas estratégias de superação.

$\mathrm{O}$ exercício de refletir deve ser constante. Pretendemos contribuir para área educacional, mesmo que modestamente, com as nossas histórias de vida na escola, assim como nossas estratégias de superação e de sobrevivência na profissão docente. Esperamos contribuir com a área da educação e com os leitores, sejam eles pesquisadores, professores, estudantes e interessados pela educação ampliando nossa compreensão sobre o nosso próprio trabalho.

Os trabalhos aqui apresentados foram organizados da seguinte forma: cada capítulo trará o relato de experiência contendo as manifestações dos autores, vivências, histórias de vida, e concomitantemente realizará uma discussão teórica sobre o relato apresentado.

Cada capítulo foi escrito por um autor. Os autores participantes são professores, diretores, coordenadores, atuantes na educação básica e no ensino superior. Portanto, os trabalhos apresentados aqui trazem as mais diversas facetas do trabalho na área educacional, desde a atuação na educação infantil até profissionais que trabalham com a formação de professores.

Por fim, o primeiro capítulo foi escrito por Aline Martins de Almeida, Doutora pelo Programa de Estudos Pós-Graduados em Educação: História, Política, Sociedade, da Pontifícia Universidade Católica de São Paulo, mestre pelo mesmo Programa e graduada em Pedagogia pela Pontifícia Universidade Católica de São Paulo. Realizou seu Estágio de doutorado-sanduíche na Universidade de Coimbra. Atualmente é docente na Universidade Presbiteriana Mackenzie e Universidade Metropolitana de Santos. Nesta coletânea a autora contribuiu com um artigo abordando suas experiências na educação infantil e no ensino fundamental, com enfoque na educação inclusiva e na formação de professores.

Já o segundo capítulo foi escrito por por Higor Ribeiro de Araújo Lima Macedo, graduado em Letras, Ciências Sociais e Pedagogia. Possui pós-graduação em: Docência do Ensino Superior, Tecnologia Assistiva, Comunicação Alternativa e Língua de sinais, Deficiência Intelectual, Psicopedagogia, Gestão pública, Educação especial com ênfase em Transtornos Globais do Desenvolvimento e Altas habilidades, Educação especial 
com ênfase em Deficiência visual, auditiva e surdocegueira e Neuropsicopedagogia. O autor tem experiência como professor de educação infantil, ensino fundamental I e II e no Ensino médio, e também, é professor designado como responsável pelo atendimento Educacional Especializado na Sala de Recursos Multifuncionais. No capítulo apresentado nesta coletânea, o autor trata da formação de professores do ensino básico nos dias atuais, destacando ser necessário uma leitura atenta e criteriosa dos contextos sociais, políticos, econômicos e culturais. Higor apresenta suas experiências no início de sua formação e na sua carreira, ambas concentradas na educação especial. O referencial teórico utilizado para o embasamento de seu trabalho foram os estudos de Paulo Freire.

O terceiro capítulo foi escrito por Izolda Maria Batista graduada em Pedagogia, com habilitação em Educação Especial e Orientação Pedagógica, especialista em Educação Infantil, possui pós-graduação em Educação Empreendedora pela Universidade Federal São João Del Rey- UFSJ (2011). Tem mestrado em Educação: História, Política, Sociedade pela Pontifícia Universidade Católica de São Paulo PUCSP (2017). E atualmente é Doutoranda pelo Programa de Pós-graduação Educação: História, Política, Sociedade da PUC/SP. A autora tem ampla experiência na área educacional incluindo o trabalho na educação infantil, também como alfabetizadora no ensino fundamental e EJA (Educação de Jovens e adultos) e teve experiências em equipes gestoras, como coordenadora e gestora de instituições escolares da rede pública. Nesta coletânea, Izolda contribuiu com um trabalho onde o relato de experiência traz a luz, o trabalho da equipe gestora num ano atípico onde a PANDEMIA da COVID-19 assolou o mundo todo. A autora apresenta neste trabalho o cenário educacional reorganizado para atender a demanda dos alunos da Educação infantil em meio a uma situação nunca vivida por essa geração. A análise teórica realizada pela autora teve embasamento em autores como: Licínio Lima (2011), Falk (2011), Vygotsky (2016), Rinaldi (2018), Paro (2018), Marin (2019), Freire (1996), Bourdieu (2018).

O quarto capítulo foi autoria de Cristina Leika Horii, licenciada em Física e Pedagogia pela Universidade de São Paulo. Mestre em ensino de Ciências pelo Programa de Pós-Graduação Interunidades da mesma universidade. Especialização em Educação em Saúde no Atendimento Escolar Hospitalar: Modalidade Residência pela UNIFESP/GRAACC. Sua experiência inclui a atuação no Hospital Oncológico 
Pediátrico, na Educação Infantil paulistana e agora como coordenadora pedagógica na mesma rede. Em seu artigo a autora analisou sua própria construção identitária profissional, utilizando o conceito de "Rito de Passagem" A referência teórica deste artigo foi embasada em autores como: Katz (1968) e White (1989), Van Gennep (2011), Ferreirinho $(2005,2009)$.

No quinto capítulo, o início de carreira na profissão docente continua em pauta. Fernanda Oliveira Costa Gomes, graduada em Pedagogia, Especialista em Psicopedagogia, Doutora e Mestre em Educação: História, Política, Sociedade pela PUC de São Paulo, traz um relato de experiência onde apresenta desafios, dificuldades e superações referentes aos professores em início de carreira. O objetivo do trabalho consistiu na discussão e reflexão sobre as experiências de uma professora em início de carreira em turmas do terceiro ano do ensino fundamental. As discussões foram embasadas teoricamente a partir dos estudos de Huberman (1992) que realizou um estudo sobre o ciclo de vida profissional dos professores, identificando em cada fase características próprias da profissão docente.

O sexto capítulo foi escrito por Elaine Aparecida Pereira. A autora possui doutorado e mestrado em Educação: História, Política, Sociedade (área de concentração Educação e Ciências Sociais) com pesquisas sobre o tema das relações escolares e graduação em História pela Pontifícia Universidade Católica de São Paulo. Graduou-se em Ciências Sociais, pela Fundação Santo André. Cursou licenciatura em Pedagogia na Universidade Cidade de São Paulo. Atua como professora de História na educação básica, desde 2003, tem experiência em gestão escolar e leciona no ensino superior na área das licenciaturas. A temática abordada pela autora nesta coletânea se refere a Indisciplina e Violência em escolas de ensino fundamental da rede municipal da cidade de São Paulo. O objetivo do trabalho consistiu em analisar as experiências com base em autores que se dedicam à discussão desses temas e sua relação com o contexto social em que a escola está inserida. Portanto, autores como Adorno, Charlot, Fanfani e Ianni foram utilizados como embasamento teórico, mais especificamente a partir dos conceitos de violência na escola, violência à escola, transgressão, autoridade esclarecida e condescendência pedagógica.

O sétimo capítulo foi de autoria de Hugo Leonardo de Almeida, professor da rede pública da cidade de São Paulo, Graduado em Pedagogia e Letras, possui 
experiência como professor do ensino fundamental I, Educação infantil e Gestão escolar. Nesta coletânea o autor contribuiu abordando o ensino e aprendizagem da Língua Inglesa seus desafios e possibilidades. Com objetivo principal de apresentar reflexões sobre as potencialidades e dificuldades encontradas no trabalho com a língua inglesa na educação básica, o autor abordou novas possibilidades de ensino de Língua Inglesa, refletindo sobre a necessidade da inserção dos estudantes de Língua Inglesa como sujeitos usuários dessa língua num âmbito global, intercultural e multifacetado.

Oitavo capítulo, escrito por Sandra Maria Sanches, Mestre e Doutora em Educação: História, Política, Sociedade / PUC-SP; tem Especialização em Fundamentos de uma educação para o pensar pela Pontifícia Universidade Católica de São Paulo. Atualmente é diretora de escola na rede municipal de São Paulo. Tem ampla experiência na área de Educação, com ênfase em Gestão escolar. A autora contribuiu nesta obra com um relato de experiência que traz em pauta o Ensino remoto e a Pandemia. A autora utilizou os estudos de Bourdieu para analisar as circunstâncias do trabalho pedagógico nas escolas públicas de São Paulo.

O nono capítulo foi escrito por Lúcia Matias Da Silva e Márcia Maria Martinelli. Lúcia é licenciada em Geografia e Pedagogia, Especialista em Gestão Escolar, tem Mestrado e Doutorado em Educação. Sua experiência na área educacional inclui atuação na Escola de Aplicação da Faculdade de Educação da Universidade de São Paulo EAFEUSP, Faculdades Integradas Potencial - FIP Cotia. Márcia Maria é licenciada em Letras e Pedagogia, tem Mestrado em Linguística, Doutorado em Língua Portuguesa, e atua como professora na Faculdades Integradas Potencial - FIP - Cotia. O artigo apresentado pelas autoras traz uma narrativa da experiência profissional transformada após a trajetória da pós-graduação. Os conceitos de Habitus e modos operandi foram utilizados pelas autoras para desenvolver uma reflexão sobre a articulação entre teoria e prática, ressaltando que a apropriação dos conhecimentos científicos levam os profissionais a enxergar seu trabalho à luz do conhecimento, podendo assim exercer sua função plena e conscientemente, se distanciando da uma conduta de executor de tarefas.

O capítulo de número dez foi escrito por Diego Moreira. Doutorando e Mestre em Educação pela PUC-SP. É graduado em História e Pedagogia. Há mais de 20 anos atua na carreira docente, com experiência desde o ensino fundamental até a Pós Graduação, em redes públicas e privadas. É pesquisador na área de formação de 
professores e Gestores. Leciona na Pós graduação nas áreas de Educação e Gestão de Pessoas. Coordenou cursos de Graduação e Pós Graduação em SP. Foi analista do Instituto Unibanco e apresenta o programa Educação em Pauta no grupo Cenário de Comunicação. Escreve semanalmente a coluna Educação em Pauta. Dirigiu o Instituto SEFAP de 2008 a 2017. Atualmente, dirige a ESCOLA dos SABERES. Nesta coletânea, o autor contribuiu com um artigo que apresenta a trajetória da formação e profissionalização dos egressos do CEFAM. Numa leitura pessoal da história de vida e percurso formativo retomou momentos da sua vida e conectou com a história do magistério e do movimento de fundação do CEFAM no Brasil e em São Paulo.

Por fim, décimo primeiro capítulo foi escrito por David Budeus Franco, graduado em Letras Português - Inglês pela Universidade de São Paulo (2015), em Comunicação Social pela Pontifícia Universidade Católica de São Paulo (2008), em Pedagogia pela Universidade Cidade de São Paulo (2017), tem mestrado em Educação: História, Política, Sociedade pela Pontifícia Universidade Católica de São Paulo (2014) e doutorado em Educação: História, Política, Sociedade pela Pontifícia Universidade Católica de São Paulo (2018). Tem experiência na área de Educação, com ênfase em Educação, atuando principalmente em temas como: formação, ensino médio, teoria crítica da sociedade, cultura, sociedade e juventude. Neste capítulo o autor apresenta por meio das experiências na docência, de suas observações e reflexões, uma possibilidade de compreensão do cotidiano escolar em tempos de corrosão dos direitos e ampliação do tempo de trabalho em meio a Pandemia da COVID-19. Os estudos de Adorno (2010), Freitas (2018), Fontes (2018), Marx e Engels (1983) foram utilizados pelo o autor para o embasamento teórico.

Feita a apresentação dos trabalhos, é válido ressaltar que a relação teoria e prática é um exercício constantemente necessário. A cada momento, a cada dia, no passar dos anos, a reflexão, a análise e estudos sobre nossas vidas nas instituições de ensino são essenciais. O exercício de escrever relatos de experiência é uma forma de levar os leitores e perceber que existem teorias em todas as práticas, e que toda ação pedagógica, ou relacionada ao pedagógico, deve ser fundamentada cientificamente. Do contrário, nos tornaremos tarefeiros, acríticos e nosso trabalho facilmente fragilizado.

Nos últimos anos temos vivenciado uma série de ataques a professores, educadores e pesquisadores. A ciência tem sido questionada, e atacada, e nós 
professores recorrentemente sofremos os resquícios deste processo. Somos questionados, somos observados com desconfiança, como um grupo de manipuladores e "pregam" uma certa ideologia. Mas, essa situação não é nova, Martin Lawn (2001) em seu artigo Fabricação da identidade docente, já trazia em pauta o fato de que o professor é um profissional que causa pânico no Estado. Justamente porque o professor tem conhecimentos de Ensino Superior, e que cotidianamente se aproxima dos marginalizados e dos excluídos. O princípio de que a educação deve ser emancipatória, como afirmou Adorno (1967), ou a defesa de Freire (1967) de que a educação deve ser libertadora já causou calafrios naqueles que se beneficiam do status quo desta sociedade desigual. E de fato, com certeza, definitivamente, para eles, o professor é um perigo.

Enfim, numa sociedade que gradativamente desvaloriza o trabalho docente e distorce as intenções dos profissionais da educação, essa coletânea teve uma intenção de dar voz, dar a palavra aos profissionais da educação. As histórias, as circunstâncias e desafios que enfrentam todos os dias foram explanados aqui como um ato de resistência e de registro da realidade da educação brasileira, assim como a capacidade de retirar de suas práticas e experiências um conhecimento regado a leitura, estudos e pesquisa.

Portanto... VIVA A CIÊNCIA!

\section{VIVA OS PESQUISADORES!}

\section{VIVA OS PROFISSIONAIS DA EDUCAÇÃO!}

Com a palavra os profissionais da educação. Boa leitura! 


\section{PREFÁCIO}

Fazer o prefácio de uma obra, qualquer que seja, é sempre um desafio, uma responsabilidade, mas também representa o respeito e a amizade que une o(s) autor(es) do(s) texto(s) e quem escreve sobre ele(s) em seu lançamento. Assim, desde logo, quero agradecer por ter sido a pessoa escolhida para apresentar, aos leitores, a obra que aqui está.

Trata-se de um produto construído a muitas mãos, orientadas pela mão segura da dona da ideia central, em propor o tema e trazer colegas para a colaboração.

Foi assim que se construiu esta obra que considero da maior relevância por seus temas particulares, cada um contribuindo de forma exemplar para o grande tema do livro: a vida diária das escolas abrangendo uma temática em várias áreas, todas fundamentadas para a compreensão do que se passa efetivamente nas salas de aula e nos demais ambientes escolares.

Os relatos de experiências aqui apresentados são resultantes da ação de dar voz aos professores, diretores e coordenadores de escolas compondo coletânea sobre diferentes aspectos da vida profissional, os problemas e suas superações, enfrentamentos de desafios, relatos de suas histórias, estratégias criadas para diversas situações reais.

Temas como o da educação infantil no início da pandemia e a reorganização do trabalho; reflexões sobre educação especial e construção identitária de colegas; superação de desafios e dificuldades de início de carreira; questões sobre indisciplina e violência em escolas e suas relações com o contexto social; preparo para operar com o ensino remoto e a pandemia; potencialidades e dificuldades com o ensino de língua inglesa; e experiências profissionais após a pós-graduação; são temas relatados pelos autores permitindo interessante e rico relato de nossa realidade diária, uma fonte de informações sobre o que é a escola e a tarefa de ensinar nela.

Certamente muitos de nós já devem ter ouvido falar, ou mesmo vivenciar, situações similares, mas os relatos aqui presentes podem auxiliar muitos colegas na compreensão de situações já vividas, que ainda vivenciam ou vivenciarão, exatamente pelo vigor dos relatos e seus tons de realidade. 
Parabéns à autora pela ideia e pelo esforço em organizar todo esse trabalho, pois não é uma tarefa simples, desde a opção pelo tema até a recepção final dos textos, acrescida da preocupação em aguardar as obras dos colegas e verificar as dificuldades que eles enfrentavam auxiliando na superação. Além disso, ficar na expectativa dos trabalhos finais, os quais, posso afirmar pela minha leitura, certamente trouxeram resultados muito bons e contaram com o apoio da coordenadora.

Desejo todo sucesso na divulgação e na utilização desse material por muitos professores e estudantes. Contem comigo para tal tarefa.

Meus parabéns.

Alda Junqueira Marin

Primavera de 2021. 


\section{SUMÁRIO}

1. É Possível Incluir Sem Excluir?

Aline Martins De Almeida

2. Ação docente enquanto objeto de análise sociohistórica da contemporaneidade na perspectiva da educação especial

Higor Ribeiro De Araújo Lima Macedo

3. Desafios Da Direção Escolar Na Pandemia Da Covid/19: Uma Experiência Na Rede Municipal De São Paulo

Izolda Maria Batista

4. De aluna para professora: ritos de passagem na construção da identidade docente

Cristina Leika Horii

5. Experiências e práticas de uma professora iniciante: terceiro ano do ensino fundamental em foco

Fernanda Oliveira Costa Gomes

6. Os desafios da profissão docente: transgressões e violência na escola

Elaine Aparecida Pereira

7. Limites e possibilidades no processo de ensino e aprendizagem da língua inglesa na educação básica: uma reflexão metodológica

Hugo Leonardo de Almeida

8. Ensino remoto e pandemia: breves considerações

Sandra maria sanches

9. Identidade e memória: ressignificando caminhos

Lúcia Matias da Silva, Márcia Maria Martinelli Elia

10. O cefam e a formação inicial de uma geração de professores

Diego Moreira

11. Relato de experiência na pandemia: a atividade docente em tempos de corrosão de direitos e ampliação do tempo de trabalho

David Budeus Franco

POSFÁCIO

ÍNDICE REMISSIVO 


\title{
É POSSÍVEL INCLUIR SEM EXCLUIR?
}

\section{IT IS POSSIBLE TO INCLUDE WITHOUT EXCLUDING?}

\section{RESUMO}

Aline Martins de Almeida ${ }^{1}$

Este trabalho tem por finalidade apresentar e refletir sobre as práticas docentes inclusivas tendo como foco a formação inicial e continuada desta docente da educação básica no período dos anos 2000 - 2001, que atuou na educação infantil e no ensino fundamental (anos iniciais). Por meio das memórias e também de portfólios pessoais, trataremos também da formação docente em nível médio, explicitando a formação de professores do estado de São Paulo por meio do projeto CEFAM (Centro Específico de Formação e Aperfeiçoamento do Magistério) e da formação pedagógica universitária simultânea ao primeiro emprego como docente da educação infantil no município de Jandira aos 18 anos. Rememorar tais lembranças nos faz refletir sobre alguns dados que estavam sendo discutidos: as políticas de financiamento, as mudanças que os Parâmetros Curriculares Nacionais e os Referenciais Curriculares Nacionais para a Educação Infantil impactavam o cotidiano escolar. Além destas questões, também iniciava-se o trabalho inclusivo com as crianças com deficiências ou transtornos e as dificuldades de aprendizagem eram pautas nas reuniões pedagógicas. Deste modo, abordaremos a trajetória desta professora que iniciou o estágio aos 16 anos e apresentará os desafios não apenas do primeiro dia de aula de crianças, mas o primeiro dia de aula de uma estagiária e de uma docente que estava lidando não apenas com um novo marco profissional em sua vida, mas que conviveu com os impactos das políticas, dos currículos e das resistências docentes em trabalhar com mudanças.

Palavras-chave: Formação inicial. Formação continuada. Docência.

\section{PRIMEIRAS LEMBRANÇAS}

\begin{abstract}
Gosto de ser gente porque, mesmo sabendo que as condições materiais, econômicas, sociais e políticas, culturais e ideológicas em que nos achamos geram quase sempre barreiras de difícil superação para o cumprimento de nossa tarefa histórica de mudar o mundo, sei também que os obstáculos não se eternizam.

[...] A conscientização é exigência humana, é um dos caminhos para a posta em prática da curiosidade epistemológica. (FREIRE, 1996, p. 54)
\end{abstract}

\footnotetext{
${ }^{1}$ Doutora pelo Programa de Estudos Pós-Graduados em Educação: História, Política, Sociedade, da Pontifícia Universidade Católica de São Paulo, mestre pelo mesmo Programa e graduada em Pedagogia pela Pontifícia Universidade Católica de São Paulo. Estágio de doutorado-sanduíche na Universidade de Coimbra. Docente na Universidade Presbiteriana Mackenzie e Universidade Metropolitana de Santos.
} 
Rememorando as minhas lembranças e redigindo a citação acima, me deparei com algumas indagações: Com qual idade decidi que seria professora? Por que nunca tive "medo" de conviver com crianças com deficiências? Por que nunca entendi o problema que as pessoas tinham em relação a cor da pele? Por que as crianças "danadas" tinham tantos problemas para participarem das aulas?

Buscando algumas respostas, me recordo que sempre convivi durante a minha infância com o neto da minha madrinha que tem deficiências física e intelectual devido à falta de oxigenação no momento do nascimento; mas, sua deficiência nunca foi um empecilho, ao contrário, utilizávamos de outras estratégias para nos divertirmos como brincar que sua cadeira de rodas era um grande carro... posso afirmar que era sensacional!

No cotidiano familiar, sou filha de pai com descendência italiana e mãe com descendência negra e indígena. Gostamos de falar que nossa família é toda colorida! Inclusive, eu sou branca e meu irmão pardo. Por meio dessa riqueza étnico-racial, meus pais sempre ensinaram a importância de respeitarmos a todos, independente de cor, classe, raça ou gênero. Mas, isso não impediu que passássemos por situações de preconceito ou discriminação. Para exemplificar um destes momentos foi quando minha mãe relatou que quando estávamos no posto de saúde para recebermos a vacina, uma senhora a questionou se era minha mãe ou babá. Dói dizer que eu nunca passei por estas situações, mas as pessoas que amo, sim!

Convivendo com estas múltiplas realidades, me recordo que me apaixonei pela profissão docente logo quando iniciei a jornada escolar no parque infantil em 1991. O uniforme consistia no uso de uma camiseta branca, shorts, tênis e sacolinha vermelhas. Brincávamos, aprendíamos e tínhamos o momento adequado para a realização de cada atividade. Convivia com crianças de cada canto do bairro Jardim Rochdalle (no município de Osasco).

A "tia" Neide, como assim era conhecida naquele período, tinha um jeitinho todo especial de lidar com cada um de nós e trabalhava com uma rotina incrível: o acolhimento aos colegas da turma, as distintas lições para atender a cada criança, proposição de novas dinâmicas que nos permitia a exploração de todos os cantos do 
"parquinho" e as conversas individuais ou grupos quando o tema era comportamento. Eram momentos construtivos e me encantei com este mundo.

Foi com este olhar de encantamento, que passei a brincar de "escolinha" na garagem de casa. Foram anos brincando e simulando a prática docente em conformidade ao que vivia na escola: ora gritava, mudava todos de lugares, chamava a diretora, retirava os alunos da sala, ora corrigia os cadernos dos alunos apontando os grandes erros. Neste percurso, passei por todos os processos: alfabetização e letramento, cursando os antigos ciclos CBI (ciclo básico inicial) e CBC (ciclo básico continuado) os atuais três primeiros anos de alfabetização da educação básica, as $3^{\mathrm{a}}$ e $4^{\mathrm{a}}$ séries completando assim o ciclo do ensino fundamental $\mathrm{I}$, o ginásio $\left(5^{\mathrm{a}}\right.$ a $8^{\mathrm{a}}$ séries - ciclo completo do ensino fundamental II) e no ano de 1999 fui aprovada no processo seletivo para cursar o ensino médio na modalidade magistério. Estava adentrando o mundo que sempre sonhei: me tornar professora... mas uma professora diferente, como a primeira docente que marcou a minha vida: a "tia" Neide, uma professora que gostava de gente!

\section{O MAGISTÉRIO}

No período de 2000 a 2003 fui aluna de uma das unidades do CEFAM (Centro Específico de Formação e Aperfeiçoamento do Magistério) no município de Osasco.

A proposta deste estabelecimento de ensino era formar, em período integral, os futuros docentes em nível médio com uma formação distinta da que estava sendo ofertada até então.

O estabelecimento de um processo de causação cumulativa, envolvendo numa ponta a má formação dos profissionais da educação e em outra o posterior desempenho insatisfatório dos mesmos junto à clientela dos diversos graus de ensino, tende, no atual quadro da educação brasileira, a deteriorar ainda mais nosso sistema escolar. $\mathrm{Na}$ tentativa de reverter tal processo, a Secretaria da Educação do Estado de São Paulo criou, através do Decreto 28.089/88 de 13 de janeiro de 1988, os CEFAMs: "Centros Específicos de Formação e Aperfeiçoamento do Magistério". Esses Centros passaram a funcionar a partir de 08 de fevereiro de 1988, segundo normas contidas na Resolução SE 14/88 de 28/01/88, que disciplinava sua instalação e funcionamento (PETRUCI, 1994, p. 9).

O currículo abordado era diferenciado: no período matutino, aprendíamos os saberes propostos na grade comum curricular para o Ensino Médio, enquanto que, no 
período vespertino, as atividades tinham como foco o enriquecimento curricular acerca das disciplinas estudadas. Este formato de disciplina estava previsto para os dois primeiros anos formativos. Já os dois últimos anos consistiam em disciplinas direcionadas à formação pedagógica.

Os Centros de Formação e Aperfeiçoamento do Magistério não se destinam a reviver as antigas Escolas Normais ou Institutos de Educação, mas propõem uma outra filosofia e uma outra prática pedagógica, voltadas para a habilitação do magistério, a qual tem atualmente suas reais funções descaracterizadas. Dentro desta perspectiva é que devem ser vistos os objetivos propostos para esses Centros:

a) "dar prioridade efetiva à formação dos professores das séries iniciais do primeiro grau e pré-escola;

b) "aprimorar a formação dos professores dos cursos de Habilitação ao Magistério para que se tornem os grandes artífices da qualidade do ensino" (SE/CENP, nov.1988, p.4 e 5) (PETRUCI, 1994, p. 11).

Neste período formativo, estudávamos os impactos da LDB nº 9394 de 1996 e dos Parâmetros Curriculares Nacionais para o Ensino Fundamental (1998) e dos Referenciais Curriculares Nacionais para a Educação Infantil (1998). Estudando os documentos no espaço escolar pareciam ser simples, mas quando pisávamos o "chão da escola" muito do que era proposto não era vivenciado. Os professores não gostavam dos novos documentos e nos desmotivavam num momento em que era preciso aprender juntos.

Não vou negar que pensei em mudar de área. Inclusive, prestei vestibular para uma área totalmente distinta à educação. Não queria conviver com reclamações cotidianas ou ter como recurso didático o uso do mimeógrafo, como o único material que produzia atividades diferentes, além do uso do caderno, para a turma. O ano de 2002, particularmente, me dizia que o sonho em ser como a "tia" Neide foi um engano e que esta carreira não seria para mim.

Mas, 2003, foi um ano que me inspirou a ser professora novamente. O estágio foi vivenciado de uma forma totalmente diferente! Conheci profissionais que, de fato amavam o que faziam, mesmo com as dificuldades. Também elaboramos um projeto de atuação numa escola de periferia do município com metodologias diferenciadas a partir dos apontamentos dos professores. Foi um trabalho coletivo, construído coletivamente. Vivenciei exatamente os estágios de sobrevivência e descoberta propostos por Huberman (2000, p. 39): 
O aspecto da "sobrevivência" traduz o que se chama vulgarmente o "choque do real", a confrontação inicial com a complexidade da situação profissional: o tactear constante, a preocupação consigo próprio ("Estou-me a aguentar?"), a distância entre os ideais e as realidades quotidianas da sala de aula, a fragmentação do trabalho, a dificuldade em fazer face, simultaneamente, à relação pedagógica e à transmissão de conhecimentos, a oscilação entre relações demasiado íntimas e demasiado distantes, dificuldades com alunos que criam problemas, com material didático inadequado, etc.

Em contrapartida, o aspecto da "descoberta" traduz o entusiasmo inicial, a experimentação, a exaltação por estar, finalmente, em situação de responsabilidade (ter a sua sala de aula, os seus alunos, o seu programa), por se sentir colega num determinado corpo profissional.

Os conceitos de sobrevivência e descoberta proposto por Huberman (2000) devem ser movimentos presentes na formação docente. Vivenciar a realidade da escola entendendo e compreendendo os processos de conquistas, as dificuldades, os problemas e os desafios são formas de estabelecimento de diálogos entre os formadores dos diversos níveis de ensino e os formandos. Estas eram propostas que vivenciei no magistério e que amparam a prática docente. No entanto, vivenciei um episódio que até então não tinha experienciado: o primeiro dia de aula... mas não no papel de aluno, mas sim, o da professora!

\section{O PRIMEIRO DIA DE AULA DE UMA DOCENTE}

Lembro-me como se fosse hoje o meu primeiro dia como professora regente. $\mathrm{O}$ ano era 2004. A minha turma era o Pré II M na Escola Municipal de Ensino Infantil e Fundamental Cidade de Kameoka localizada no município de Jandira.

Meu primeiro emprego... e como funcionária pública, efetiva da rede. Era o sonho de qualquer jovem que terminara a sua primeira formação em nível de magistério. Organizei e decorei toda a sala, fiz lembrancinhas para o primeiro dia de aula, produzi atividades lúdicas, dinâmicas e gamificações para as crianças. Tudo planejado conforme aprendemos. No entanto, não foi trabalhado, como seria o primeiro dia de aula de um professor.

Posso dizer e afirmar que foi apavorante. Os portões abriram e eu não sabia como recepcionar aqueles que também estavam assustados em deixar seus filhos e suas 
filhas num novo ambiente e com uma pessoa desconhecida: os familiares dos educandos. Entre a recepção e a despedida, o choro prevalecia. E, quando os responsáveis me viam, me olhavam com decepção e muitos alegavam que eu era uma menina e que não sentiam confiança em deixar seus filhos sob meus cuidados. Foi um momento desesperador e tais "choques" podem ser evidenciados.

Nos estudos de Michael Huberman (1995) são apresentadas as fases do início da carreira docente e uma das fases é o choque da realidade, que consiste num momento de frustração por não encontrar no ambiente de trabalho o que havia idealizado previamente. A pesquisa de Oliveira (2015) aponta para tais fatores, pois a pesquisa identificou professores frustrados diante do choque da realidade, entre distanciamento da formação obtida na faculdade e a realidade das salas de aulas (GOMES, 2020, p. 26).

Os sentimentos de choques e de frustrações se misturavam ao ponto de não saber como reagir. Foi quando minha gestora adentrou a sala e fez com que estes sentimentos fossem modificados. Ela conversou com os pais e falou da minha capacidade como professora e narrou os passos prévios que todo profissional do serviço público precisa percorrer: aprovação em concurso, convocação, comprovação da formação, exames, termos até o efetivo exercício. E a frase mais bonita que poderia acalentar meu coração foi proferida pela gestora: "Todo profissional precisa iniciar a sua carreira. Eis o momento da professora Aline. Aqueles que desejarem que seus filhos não estudem com ela, podem passar na secretaria e solicitar a transferência para outra unidade escolar".

Aquelas palavras me deram ânimo. Me senti incluída num espaço que me sentia sozinha como profissional. Mas... trazendo a temática à tona, eu não sei se o discurso foi adequado quando lutamos por uma educação que supere as exclusões vivenciadas pelos sujeitos. Naquele momento, eu me senti incluída e, as famílias? Esta indagação remeteu às memórias da infância e me levaram a repensar sobre outro tópico: precisamos reconhecer os nossos (pré) conceitos para que possamos acolher a todos?

No próximo tópico, gostaria de compartilhar das experiências vivenciadas a partir das fontes para a base de conhecimento para o ensino trabalhadas por Shulman (2014) e das dimensões apontadas por André (1991). 


\section{O COTIDIANO FORMATIVO DE UMA PROFESSORA}

Portanto, o padrão de instrução de Nancy, seu estilo de ensino, não é simplesmente uniforme ou previsível. Ela responde de maneira flexível à dificuldade e ao caráter do conteúdo, às capacidades dos alunos (que podem mudar até ao longo do mesmo curso) e aos seus propósitos educacionais. Ela pode não apenas reger a orquestra do púlpito, mas pode também se afastar e assisti-la tocando virtuosamente sozinha.

Quais são as crenças, concepções e práticas de Nancy e como ela sabe o que fazer para poder ensinar como ensina? Será que outros professores podem ser preparados para ensinar com tanta habilidade? A esperança de que ensinar como Nancy possa se tornar típico, em vez de raro, motiva muitos dos esforços para as reformas do ensino recentemente propostas (SHULMAN, 2014, p. 199).

A experiência de Nancy narrada por Shulman (2014) nos leva a múltiplos olhares reflexivos sobre o processo formativo da atuação docente e as correlações estabelecidas com as legislações e as políticas educacionais. Para tanto, e seguindo os preceitos deste autor, vamos adotar as quatro grandes fontes para a base de conhecimento para o ensino, utilizando das vivências desta professora:

\section{- $\quad$ Formação acadêmica nas áreas de conhecimento ou disciplinas}

Na primeira fonte, podemos citar tal exemplo, quando no Brasil, a LDB no 9394 de 1996, em seu artigo 62 determinara que a formação docente para atuação na educação básica deveria ser em nível superior, em cursos de licenciaturas, de graduação plena, em universidades e institutos superiores de educação, sendo admitida a formação mínima para o exercício do magistério na educação infantil e nos cinco primeiros anos do ensino fundamental, a oferecida em nível médio, na modalidade normal.

Esta nova exigência deveria ocorrer a partir de 2007 e me recordo que era uma temática de muitos debates na escola, pois, muitos docentes alegavam ser excelentes profissionais sem necessitarem de ensino superior e muitos se negavam a fazer esta formação. E, aqueles que cursavam esta modalidade (como eu) recebíamos muitas críticas. Inclusive, escutei que não era aprendendo a teoria que seria/teria uma boa prática; pois a prática adivinha com a experiência. Sentia na pele a necessidade da junção entre a pesquisa e a difusão dos saberes que eram produzidos entre as modalidades de ensino. 
Hoje, as Diretrizes Curriculares Nacionais para a formação inicial em nível superior (cursos de licenciatura, cursos de formação pedagógica para graduados e cursos de segunda licenciatura) e para a formação continuada (2015) e os programas como o PIBID (Programa Institucional de Bolsa de Iniciação à Docência) e o Residência Pedagógica visam o aperfeiçoamento da formação prática nos respectivos cursos, estabelecendo a parceria entre escola e Universidade.

\section{- Os materiais e o entorno do processo educacional institucionalizado}

Neste período de atuação docente, os temas que envolviam os currículos, materiais didáticos, organização e financiamento educacional, e a estrutura da profissão docente) ferveciam no interior da escola:

- O currículo estava sendo aprendido por meio de formações que envolviam o projeto PCN's em Ação, que eram ofertados em momentos de formação em HTPc's;

- Os debates acerca do financiamento, pois os profissionais da educação infantil e da educação de jovens e adultos não recebiam os mesmos recursos do ensino fundamental (inclusive, muitas discussões envolviam as bonificações oriundas do FUNDEF - Fundo de Manutenção e Desenvolvimento do Ensino Fundamental e de Valorização do Magistério); a "redução" de idade da educação infantil e aumento do tempo da escolarização da educação básica;

- Neste período, eu atuava concomitantemente, com a educação infantil e fundamental, em outras redes de ensino da região metropolitana de São Paulo e estas temáticas eram pautas de discussão, pois passaram a mudar planos tanto de ensino quanto de carreira dos docentes.

- Pesquisas sobre escolarização, organizações sociais, aprendizado humano, ensino e desenvolvimento, e outros fenômenos sociais e culturais que afetam o que os professores fazem

Neste período, várias publicações estavam se fazendo presentes nos espaços educacionais: além dos PCN's, as diretrizes curriculares nacionais da educação básica, a política nacional de educação especial, os trabalhos propostos pela Secretaria de 
Educação Continuada, Alfabetização e Diversidade (Secad/MEC), além dos novos referenciais publicados pela Unesco, passaram a contemplar as pautas formativas.

Recordo-me que, no ano de 2010, participei da primeira pesquisa envolvendo os sujeitos público-alvo da educação especial e seu desenvolvimento. Foi uma parceria muito bacana, pois tínhamos dúvidas de como trabalhar com estes educandos. Muitos tinham medo, outros, como eu, não sabiam se estavam no caminho certo. Não era mais uma brincadeira de crianças, estava trabalhando com o desenvolvimento de uma vida. Mas, senti falta de um dado: não recebemos os frutos oriundos deste trabalho!

Neste período, também trazemos à tona para o ambiente educacional as questões étnico-raciais e o tanto das raízes eurocêntricas que nossa sociedade foi formada. Recordo-me de um dia ensinando sobre a origem do povo brasileiro, um aluno me disse que não tinha ancestrais indígenas porque ele não iria andar nu. Escutando esta fala, dentre tantas outras, vamos percebendo os desafios docentes em reger uma orquestra que muda anualmente e que traz outras narrativas de vida.

\section{- A sabedoria que deriva da própria prática}

Quando recordo da trajetória profissional, vou sentindo os sabores e os dissabores da profissão. Os sabores de ver um aluno lendo e escrevendo as primeiras letras, um aluno que antes não interagia passando a criar e recriar múlitplas atividades com os colegas, um aluno que não falava por conta da sua deficiência, se comunicando com todos, um aluno com sérios problemas comportamentais tendo amigos e respeitando-os... São muitas ações que fortifcam a prática e nos transformam em docentes melhores.

Já os dissabores ou as frustrações também ocorrem é algo que sempre marcou a minha jornada como docente da educação básica foram os sujeitos desses momentos: não foram as crianças, mas sim, os adultos. E, são estas práticas que parecem ser silenciadas ou esquecidas e que não debatemos. Falamos tanto da participação da comunidade na escola, dos familiares, da gestão, das práticas inovadoras vivenciadas por nossos pares ou o próprio uso dos registros de desenvolvimento dos alunos de uma ano letivo para o outro. Mas... não temos esta memória registrada para que possamos re (pensar) o fazer didático ou se quer, fazemos uso dos (poucos) registros produzidos.

De acordo com SHULMAN (2014, p. 212): 
Carece de uma história da própria prática. Sem esse sistema de notação e memória, os passos seguintes, de análise, interpretação e codificação de princípios da prática, são difíceis de dar. De nossa pesquisa com professores de todos os níveis de experiência, concluímos que é extenso o conhecimento potencialmente codificável que pode ser extraído da sabedoria da prática. Os educadores simplesmente sabem muita coisa que nunca sequer tentaram articular. A maior parte da agenda da pesquisa na próxima década será coletar, comparar e interpretar o conhecimento prático dos professores com o propósito de estabelecer uma literatura de casos e codificar seus princípios, precedentes e parábolas (SHULMAN, 1986). Uma grande parte da agenda da pesquisa associada ao programa Carnegie para desenvolver novas avaliações para professores envolve a realização de estudos do tipo "sabedoria da prática". Esses estudos registram e organizam em casos o raciocínio e as ações de professores talentosos para estabelecer padrões de prática em áreas específicas do ensino.

Mas, não podemos deixar de reverberar e apreender o dinamismo próprio da vida escolar. Parafraseando André (1991, p. 72) é preciso estudá-la a partir de pelo menos três dimensões: a institucional/organizacional, a instrucional/pedagógica e a histórica/filosófica/epistemológica. Estas três dimensões não podem ser consideradas isoladamente, mas como uma unidade de múltiplas inter-relações, através das quais se procura compreender a dinâmica social expressa no cotidiano escolar.

Em conformidade com André (1992), a dimensão institucional/organizacional envolve todos os aspectos referentes ao contexto da prática escolar: formas de organização do trabalho pedagógico (como a organização das salas de aula), estruturas de poder e de decisão (as relações estabelecidas entre gestão, comunidade, corpo técnico-administrativo-docente), níveis de participação dos seus agentes, disponibilidade de recursos humanos e materiais, enfim, toda a rede de relações que se forma e transforma no acontecer diário da vida escolar.

Para ilustrar tal dimensão, recordo-me de quando conhecia a escola pela primeira vez. Atuando por 12 anos em cinco escolas distintas, o momento da apresentação era fundamental para compreender o elo entre a práxis social mais ampla e aquilo que ocorre no interior da Escola: sempre quem apresentava os espaços escolares eram os integrantes da equipe gestora, e, cada qual tinha o respectivo responsável sendo 
evidenciado os papéis que deveríamos desempenhar e cumprir para que toda a rotina atendesse a missão da escola.

Já a dimensão instrucional/pedagógica abrange todas as situações de ensino onde se dá o encontro professor-aluno-conhecimento. Para tal efetivação, esta dimensão pode ser vivenciada na elaboração dos planos de aula, dos portfólios, dos semanários, dos diários de classe e das atividades produzidas pelos educandos envolvendo todo o processo de planejamento: os conteúdos, os objetivos, as metodologias, os recursos e a avaliação.

Além de toda a dinâmica normativa que permeia esta dimensão, o que dá vida a este movimento são as atividades de interação-mediação entre educando e educadores. Uma das histórias marcantes para exemplificar esta dimensão foi quando um dos alunos mais peralta, agressivo e indisciplinado da escola (e passou a ser meu aluno por ameaçar a outra professora) me confidencializou todos os problemas que vivenciava em seu lar. A partir deste momento, o aluno mudou totalmente a sua postura tanto em relação a mim quanto aos colegas da turma.

Outra dimensão fundamental no estudo das questões do cotidiano da escola é a histórica/filosófica/epistemológica, que se refere aos pressupostos subjacentes à prática educativa. Para exemplificá-la, recordo-me do trabalho que desenvolvemos com uma turma de educação infantil no ano de 2010. Um dos alunos não reconhecia-se como negro e desrespeitava a todas as crianças que ele considerava sendo "de cor". Logo, realizamos um projeto com as crianças e com as famílias trabalhando com as relações étnico-raciais do nosso país numa perspectiva de retomada histórica, conscientização e respeito ao ser humano.

Esse âmbito de análise inclui uma reflexão sobre as determinantes sociopolíticas dessa prática, um entendimento da sua razão histórica e um exame das concepções de homem, mundo, sociedade e conhecimento nela envolvidas. Esse é o nível de explicação da prática escolar na sua totalidade e em suas múltiplas determinações, a qual não pode ser feita nem abstrata nem isoladamente, mas a partir das situações do cotidiano escolar, num movimento constante da prática para a teoria e numa volta à prática para transformá-la (ANDRÉ, 1991, p. 73)

Deste modo, é preciso ouvir a voz dos professores, a nossa voz, pois as nossas experiências nos marcam pessoalmente, profissionalmente e traduzem-se nas diversas narrativas de vidas. 


\section{CONSIDERAÇÕES FINAIS}

Compartilhar de experiências pessoais e formativas é um grande desafio, pois entregamos ao outro a nossa narrativa de vida que é marcada por muitos outros sujeitos, e, ao mesmo tempo, possibilitamos ao outro a sabedoria que deriva da própria prática.

Refletir sobre essa evolução, de criança a adulto, de estudante a professora, de aprendiz a professora iniciante, professora da educação básica e professora universitária não apenas expõe, mas ilumina os conhecimentos adquiridos e compartilhados nos campos profissional e pessoal. Muitas das nossas escolhas, dos resultados que circunscrevem nossas práticas e experiências baseiam-se em erros, acertos e como Shulman (2014) aponta em refinamentos - em uma palavra, o crescimento do conhecimento do professor - são vistos em relevo, em destaque e em câmera lenta.

Mas, percorrer e apresentar esta trajetória, nos fornece outros meios para subsidiar o trabalho e a profissionalização docente, que são as narrativas e as memórias e aqui, podemos ampliar o nosso leque: como os discentes apreendem os sucessos e os fracassos de seus docentes? Será que seguimos sempre os mesmos modelos ao estudarmos aqueles que começam a aprender a ensinar?

Dentre tantas indagações apresentadas neste ensaio, algumas respostas tornaramse dados práticos de reflexão quando atuo com quaisquer turmas, tais como: reconhecer o meus próprios preconceitos e limitações acerca de quaisquer contextos; dialogar, compartilhar e trocar informações e referenciais entre os pares e entre os discentes em múltiplos eventos que não se restrinjam apenas a um único tempo/ espaço; propor uma educação que seja de fato, humanista e emancipadora, a qual todos os sujeitos devem ser vistos como gente.

Lutar por uma educação para todos não é uma tarefa fácil. Mas acredito que o trabalho que envolva: ensinar, aprender, experienciar, subsidiar, compartilhar, esperançar, acreditar, mudar, incluir, respeitar, possibilitar são possíveis. Eis o nosso grande desafio! 


\section{REFERÊNCIAS}

ANDRE, M. E. D. Questões do cotidiano na escola de $\mathbf{1}^{\mathbf{0}}$ grau. São Paulo: Série Ideias, 1991. Disponível em: http://www.crmariocovas.sp.gov.br/pdf/ideias_11_p069-

081_c.pdf. Acesso em: 15 set. 2021.

BRASIL. Congresso Nacional. Lei de Diretrizes e Bases da Educação Nacional Lei número 9394 de 20 de dezembro de 1996. Estabelece as diretrizes e bases da educação nacional. Brasília, DF, 1996.

FREIRE, P. Pedagogia da Autonomia: saberes necessários à prática educativa. São Paulo: Paz e Terra, 1996.

GOMES, F. O. C. Professoras iniciantes e bem sucedidas: análise das estratégias didáticas de professoras bem-sucedidas no início da carreira. Tese de Doutorado em Educação: História, Política, Sociedade. São Paulo: Pontifícia Universidade Católica de São Paulo, 2020.

HUBERMAN, M. O ciclo de vida profissional dos professores. In: NÓVOA, A. (Org.). Vidas de professores. 2. ed. Porto: Porto, 2000. p.31-61.

PETRUCI, M. das G. R.M. "CEFAM - Uma proposta de formação e aperfeiçoamento de professores para o $1^{\circ}$ grau", Paidéia, FFCLRP-USP, Ribeirão Preto, 6, Fevereiro, 1994. Disponível em:

https://www.scielo.br/j/paideia/a/jjd74w65bT6PFP6WXTNDzpq/?format=pdf\&lang=pt. Acesso em 10 out. 2021.

SHULMAN, L. S. Conhecimento e ensino: fundamentos para a nova reforma. Cadernos Cenpec, São Paulo, v. 4, n. 2, p. 196-229, dez. 2014. Disponível em: http://cadernos.cenpec.org.br/cadernos/index.php/cadernos/article/view/293/297.

Acesso em: 15 set. 2021. 


\title{
AÇÃO DOCENTE ENQUANTO OBJETO DE ANÁLISE SOCIOHISTÓRICA
}

DA CONTEMPORANEIDADE NA PERSPECTIVA DA EDUCAÇÃO

ESPECIAL

\author{
TEACHING ACTION AS THE OBJECT OF SOCIO-HISTORIC ANALYSIS OF \\ CONTEMPORARYITY FROM THE PERSPECTIVE OF SPECIAL \\ EDUCATION
}

Higor Ribeiro de Araújo Lima Macedo²

\section{RESUMO}

Neste artigo constataremos como a formação de professores do ensino básico nos dias atuais requer uma leitura atenta e criteriosa dos contextos sociais, políticos, econômicos e culturais, além das premissas teóricas de alguns pensadores da educação atrelados à importância da intencionalidade e transformação da realidade no fazer docente, como o autor Paulo Freire, o qual dedicou sua vida a pensar e refletir a prática pedagógica dos educadores. Menciona-se também a ação educativa diante do aluno público-alvo da Educação Especial, pois o direito educativo é constitucional e existe a necessidade de um trabalho diversificado para atender esta clientela que adentra os portões da escola pública. É preponderante para o desenvolvimento do professor em serviço, pois amplia o embasamento didático-pedagógico do educador que necessita deste recurso para desenvolver sua ação com competência.

Palavras-Chave: Vivências. Educação. Formação docente. Estudante da educação especial

\section{INTRODUÇÃO}

No referido texto, pretende-se analisar as diversas situações pedagógicas que compõem o âmbito escolar, priorizando substantivamente as concepções teóricometodológicas coerentes que valorizem a participação do aluno da Educação Especial em ações que o tornem protagonista do processo ensino-aprendizagem.

\footnotetext{
${ }^{2} \mathrm{O}$ autor é graduado em Letras - Português e Inglês pelo Centro Universitário de Jales - UNIJALES (2018), graduação em Ciências Sociais pela Universidade Metropolitana de Santos - UNIMES (2015), pós-graduação em Educação Especial com ênfase em Transtornos Globais do Desenvolvimento e Altas Habilidades pela Faculdade São Luis (2018), pós-graduação em Educação Especial com ênfase em Deficiência Visual, Auditiva e Surdocegueira e pós-graduação em Neuropsicopedagogia pela Faculdade de Educação São Luis (2020). Trabalhou como professor de educação infantil pela Prefeitura de Mauá (2010-2012). Atualmente é professor de educação infantil e ensino fundamental I e ensino fundamental II e médio - Língua Portuguesa pela Prefeitura Municipal de São Paulo designado como Professor de Atendimento Educacional Especializado na Sala de Recursos Multifuncionais.
} 
O trabalho docente enseja a construção da sua postura ética, humana e atitudinal baseada nos princípios de responsabilidade social, seu compromisso e sua competência profissional para a melhoria na qualidade do ensino e afabilidade dos processos educacionais.

Nesta perspectiva, por meio da prática pedagógica as relações sociais presentes no dia a dia se tornam contundentes e viabilizam o amadurecimento intrapessoal e interpessoal do educador. Indubitavelmente, uma experiência uniforme e imprescindível na sociedade do século XXI.

\section{INÍCIO DE HISTÓRICO PROFISSIONAL}

Antes de iniciar os relatos acerca da intencionalidade das ações educacionais no que concerne à Educação Especial da qual faço parte no meu percurso profissional, abordarei algumas questões inerentes à formação docente.

Desta forma, enquanto criança e adolescente sempre manifestei a necessidade de ser professor, seja pelo fato de ensinar e de interagir com outras pessoas, tendo em vista que durante um período da minha infância fui introvertido e preferia muitas vezes assistir a programas e séries da extinta TV Manchete.

Nesta perspectiva, durante muito tempo pensei que este sonho de entrar no ensino superior fosse utopia, pois era oriundo de uma extrema situação de marginalização social, pois morava em uma comunidade marcada pela violência e repressão policial, sempre foi notório que durante muito tempo na história do país os indivíduos excluídos do sistema capitalista pouco participaram e contribuíram com a consolidação de uma sociedade embasada pelos princípios democráticos da diversidade humana.

Felizmente aos completar os dezoito anos de idade tive a iniciativa de pesquisar sobre os cursos de Pedagogia da minha localidade e consegui ingressar em uma determinada faculdade privada da cidade de Mauá e posteriormente fui contemplado com uma bolsa de estudos do programa "Escola da Família" do Estado de São Paulo, porque a remuneração do meu antigo trabalho da ocasião não me permitia pagar o curso mensalmente.

Por conseguinte, embora estivesse em situação financeira instável durante muito tempo, tive todas as possibilidades para permanecer no âmbito da vida acadêmica e 
finalmente concluí minha primeira graduação e depois realizar tantos cursos na área da educação, tais como Letras (Português-Inglês-Espanhol), Ciências Sociais e especializações relacionadas à Deficiência Intelectual, Língua Brasileira de Sinais (LIBRAS), Docência do Ensino Superior, Gestão Pública, Psicopedagogia Institucional, Educação Especial: Deficiência Visual, Auditiva, Surdocegueira e Transtornos Globais do desenvolvimento, Neuropsicopedagogia, Metodologia do ensino da Língua Inglesa e Supervisão Escolar.

Ao completar os vinte e dois anos de idade ingressei no serviço público da cidade de Mauá em uma escola municipal de educação infantil (EMEI), na qual permaneci durante dois anos e quatro meses até iniciar o exercício na rede municipal de São Paulo no ensino fundamental I e II.

Nestes anos de ação pedagógica me tornei regente de turmas do ciclo de alfabetização, interdisciplinar, autoral e Educação de Jovens e Adultos ( $1^{\circ}$ ao $9^{\circ}$ ano), Professor Orientador da Sala de Leitura, regente nas turmas de minigrupo, infantil I e II (EMEI), Professor em situação de Complementação de Jornada (CJ) para substituição de ausência docente e neste momento atuo como Professor de Atendimento Educacional Especializado (PAEE) para pensar coletivamente nas atividades específicas aos alunos público-alvo da Educação Especial.

Desta forma, a análise exposta tecerá considerações a respeito das ações docentes frente ao planejamento, elaboração de atividades e operacionalização de estratégias condizentes à aprendizagem de conceitos, atitudes e saberes das crianças e adolescentes que fazem parte das atribuições engendradas pelas premissas da Educação Especial.

Por isso, depreende-se que por meio da educação, o aluno tomará como parâmetro a realização de suas ações, direcionando a sua participação para que o processo educativo possa se efetivar na medida em que todos contribuem de alguma maneira para a aquisição de conhecimentos.

À guisa das discussões coletivas ao longo da carreira docente, evidencia-se a premente formação multidimensional do professor, ou seja, sua qualificação para o trabalho, conhecimentos imprescindíveis à sua cidadania e a capacidade de se expressar por intermédio de ações consistentes de argumentações crítico-reflexivas que consolidaram a sua forma de representar os contrastes, paradoxos e rupturas presentes na sua realidade escolar 
Na acepção supracitada, sempre vislumbrei que o educador deve ter a elucidação do conteúdo a ser trabalho pedagogicamente e como o efetivará, quais os recursos e materiais serão disponibilizados para atingir o patamar de qualidade educacional, a fim de viabilizar esforços coletivos para conscientizar o aluno acerca da relevância da escola no cenário atual, mas priorizar quais os momentos em que os alunos possuem acesso ao arcabouço teórico discutido, problematizado e acumulado ao longo da historicidade humana e o usufruto dos saberes no dia a dia, seja escolar ou extraescolar.

\section{PROCESSO DE APROPRIAÇÃO DE SABERES DO ALUNO COM SÍNDROME DE DOWN}

\subsection{A alfabetização em foco}

Este capítulo do trabalho científico abordará algumas questões inerentes à alfabetização e as possibilidades educativas advindas de uma ação pedagógica que contemple a inclusão efetiva do aluno com Síndrome de Down.

Sendo assim, existe a necessidade de enfatizar um breve histórico do panorama da alfabetização no Brasil nos últimos anos, principalmente no que tange à implantação da concepção socioconstrutivista no sistema brasileiro de ensino.

Historicamente, as práticas escolares de leitura e escrita abrangiam o domínio de habilidades capazes de decodificar as informações provenientes dos estudos realizados na sala de aula, sem, no entanto, abarcar o contexto de vida da sociedade, bem como a individualidade do corpo discente e suas formas de pensar, agir e fazer. Havia a predominância da concepção tradicional focada no ensino, de modo a favorecer a formação de indivíduos que reproduzissem a maneira pela qual a classe dominante visualizava e percebia a realidade social.

Em contrapartida, nos primórdios do século XX, com os estudos focados na psicologia e pedagogia, alguns países estavam desenvolvendo pesquisas de como se procede a formação humana, mediante influências de cunho afetivo, biológico, social e psíquico. Cita-se o conceituado biólogo Jean Piaget, que elaborou teorias acerca do ser humano, como inteligência e aquisição de conhecimentos.

Nesta perspectiva, com a progressiva abertura política decorrente da ruptura do período da Ditadura Militar (1964-1985), da qual se engendravam ações pedagógicas 
que manipulavam o pensamento dos alunos democratizaram gradualmente o acesso dos alunos oriundos das classes populares e com deficiência, o cenário da educação começou a gerar mudanças para novas e inovadoras práticas de ensino, como o acesso, equidade e permanência dos discentes nas escolas, tivessem quadro diagnóstico de deficiência ou não e formas diferenciadas de se repensar a alfabetização.

Reiteram-se primorosamente as contribuições teóricas de Ana Teberosky e Emilia Ferreiro, que pesquisaram quais os percursos utilizados pelos alunos no processo de escrita, tendo em vista que as experiências e aprendizagens são distintas e ao docente cabe promover atividades significativas que contemplem a fase na qual cada estudante está estritamente ligado, por causa das saberes que possui.

Por conseguinte, houve implicações diretas na formação do professor nos cursos de Magistério, sejam para pensar nova postura ou para entender qual o estágio de desenvolvimento em que o educando está situado.

No bojo da acepção, os estudos teóricos preconizavam que a alfabetização necessita se articular às diferentes formas de utilizar a linguagem humana para entender e interpretar a realidade e:
A escrita pode ser concebida de duas formas muito diferentes e conforme o modo de considerá-la as consequências pedagógicas mudam drasticamente. A escrita pode ser considerada como uma representação da linguagem ou como um código de transcrição gráfica das unidades sonoras (FERREIRO, 2001, p. 10).

Neste sentido, a escola considerou relevante a proposição de abarcar a leitura concatenada à escrita, com vistas a formar alunos proficientes na língua padrão e que atendessem às demandas sociais.

Todavia, os preceitos e fundamentações da concepção socioconstrutivista não englobam eficazmente as prerrogativas de compreensão de grande parte dos educadores. Isto se deve à implantação desprovida de reflexão e debates a respeito das condições psicogenéticas do alunado, pois as realidades escolares são adversas e as ações/atribuições docentes precisam ser modificadas e repensadas.

Após a disseminação das propostas descritas anteriormente serem operacionalizadas, os cursos de formação inicial começaram a salientar as diferentes vertentes da questão do processo ensino e aprendizagem, a fim de proporcionar o 
conhecimento das concepções vigentes que interferem diretamente no sucesso escolar do alunado.

Pode-se frisar a visão tradicional (aluno desprovido de saberes e professor sabe tudo), visão comportamentalista (estímulo e resposta na ação educativa), visão humanista (o aluno é considerado a partir da sua totalidade - cabeça e corpo), visão socioconstrutivista (o aluno aprende mediante as interações sociais e maturidade) e a visão sociocultural (o professor e aluno aprendem o conceito por intermédio de pesquisas e reflexão sobre o objeto de estudo).

Com a menção de como se procede a alfabetização na sala de aula, como a abordagem teórico-prática, as intervenções pedagógicas se tornaram cada vez mais pontuais e as atividades que exigiam a cópia, muitas vezes sem a devida reflexão, deixaram de ser utilizadas cotidianamente, embora algumas escolas adotem a escrita mecânica e sem significado para o aluno.

Por isso, a alfabetização proveniente da ação e reflexão constantes e permanentes ressalta a perspectiva do aluno sobressair pensar acerca das situações dia a dia, com clareza e posicionamento crítico e:

\footnotetext{
No momento em que os indivíduos, atuando e refletindo, são capazes de perceber o condicionamento de sua percepção pela estrutura em que se encontram, sua percepção começa a mudar, embora isto não signifique ainda a mudança da estrutura. É algo importante perceber que a realidade social é transformável; que feita pelos homens, pelos homens pode ser mudada; que não é algo intocável, um fado, uma sina, diante de que só houvesse um caminho: a acomodação a ela (FREIRE, 2001, p. 46).
}

$\mathrm{Na}$ verdade, o docente que elabora estratégias e propõe métodos de ensino condizentes com a aprendizagem do educando, incentiva-o a descobrir caminhos que, sem a sua mediação, não teria condições biopsicossociais para desenvolver a visão e percepção de mundo e desbravar e conhecer as suas características e especificidades.

Outro apontamento visível nas classes de alfabetização centra-se na quantidade de alunos em uma mesma sala, abrangendo um número elevado de estudantes por sala. Neste horizonte, com a ampliação do acesso e obrigatoriedade da frequência de crianças e adolescentes entre quatro e dezessete anos, as escolas passaram a contar com uma grande demanda de estudantes que estão matriculados na rede regular de ensino. 
Entretanto, em algumas situações do cotidiano escolar, torna-se inviável manter a qualidade do processo educativo para os alunos que necessitam de uma atenção redobrada, até porque estão nos anos iniciais do ensino fundamental, que farão diferença no que diz respeito à aprendizagem de conteúdo, habilidades e competências durante toda a escolaridade.

$\mathrm{Na}$ ação alfabetizadora, um destaque a ser realizado e que necessita de um olhar específico com apoio de todos os profissionais da educação, são os alunos com deficiência, entre os quais citamos aqueles com Síndrome de Down.

\subsection{A alfabetização e o processo de leitura}

A consolidação da leitura e escrita é um processo de concatenação do exercício contínuo da leitura e das diferentes relações culturais e cognitivas que se estabelecem a partir da decodificação e codificação do signo linguístico presentes nas distintas instâncias sociais e as informações e que são armazenadas no cérebro acerca do que está sendo lido e interpretado.

No bojo desta acepção, a tarefa de estudar necessita de um atrativo especial que está embutido na dedicação e no contexto de ler como um escritor, pois neste momento há uma prerrogativa de se entregar de forma contundente ao que está escrito, a atenção meticulosa na construção sintática de cada palavra e a vivência constante sob a diversidade de portadores textuais e gêneros literários.

Porém, estar em contato com o mundo letrado não será suficiente para o aluno submergir na cultura escrita, mas será necessário aprender a ler e escrever. Indubitavelmente, esta é a função social da escola: ensinar aqueles que mais precisam, por intermédio de ações intencionais, estratégias e métodos distintos de estudo.

Ademais, o processo de ensino e aprendizagem prioriza habilidades e competências que viabilizarão aos discentes selecionarem variados textos que se adequaram à problemática que almejam compreender, como pesquisas, entretenimento $\mathrm{e}$ de cunho científico, a fim de se tornarem leitores competentes nos assuntos, fatos e conceitos pertinentes ao mundo contemporâneo.

Mesmo a escola reconhecendo a acessibilidade de todos os alunos de diferentes credos religiosos, idiossincrasias, origens sociais, salienta-se a preponderância de os educandos com deficiência, que no caso deste trabalho são as crianças com Síndrome de 
Down, deve-se valorizar a diversificação do processo de escrita e leitura nas propostas pedagógicas vigentes nas aulas. Contribuem nesta perspectiva as Diretrizes Curriculares para a Educação Especial (2001) e proferem que:

\begin{abstract}
Essa reflexão favorece o encontro de possibilidades, das capacidades de que cada um é dotado, facilitando a verdadeira inclusão. A interdependência de cada face desse prisma possibilitará a abertura do indivíduo para com o outro, decorrente da aceitação da condição humana. Aproximando-se, assim, as duas realidades - a sua e a do outro - visualiza-se a possibilidade de interação e extensão de si mesmo (BRASIL, 2001, p. 25)
\end{abstract}

Neste horizonte, percebe-se que para os alunos precisam ser oportunizadas condições para que eles desenvolvam capacidades necessárias para a execução de uma atividade ou um pensamento crítico, da qual desencadeiam formas variadas de fazer, pensar, agir em consonância com os princípios da inclusão escolar, desde que a unidade pedagógica propicie situações em que a leitura faça parte da rotina diária.

As dificuldades apresentadas por uma parcela de alunos da rede regular de ensino, desde os anos iniciais e finais do ensino fundamental e que poderão acompanhálos até o ensino superior, estão intrinsecamente relacionados à deficiência sociocultural no processo de ensino e aprendizagem, à habilidade cognitiva da escrita e compreensão em leitura.

Quanto a estas premissas, um item a ser relevado está norteado pelo que antecipa o ato de ler é a observação e aperfeiçoamento que não é decorrente de grandes produções literárias, mas, sobretudo da interiorização como resultado da leitura realizada, que influencia na escrita e na recriação subjetiva das ideias do leitor e escritor.

Sendo assim, a habilidade de avaliar o texto em suas especificidades e particularidades está focalizada na metacognição e envolve a capacidade que o discente possui para compreender o gênero textual a partir da consolidação da competência linguística condizente para interpretar determinado artigo, poema e/ou resumo.

Com este foco, pode-se reiterar que essas estratégias são resultados do desenvolvimento paulatino da metacognição, com interferência da maturidade, do comportamento leitor que se afirma gradualmente quando se lê, principalmente nos alunos que leem com assiduidade e da compreensão do que está lido.

Mas há de se ponderar um aspecto de dimensão cognitiva e de suma imprescindibilidade, que influi na formação do leitor fluente e está articulado com a 
técnica de saber selecionar, sistematizar e avaliar o que se lê, com vistas a definir os objetivos propostos da leitura, reconhecer o que é preponderante na argumentação textual, mensurar a qualidade do entendimento das ideias do autor e evidenciar meios para corrigir possíveis falhas engendradas de cansaço, distração ou ruídos de comunicação, tendo como solução a necessidade de reler o trecho do texto para o qual não houve compreensão.

Indiscutivelmente, como o conhecimento é adquirido, formalizado e sistematizado na interação com outros indivíduos mais capazes, a aquisição de saberes acontece por meio da relação estrita entre o leitor, conceitos e escritor, estabelecendo uma tríade de eixos que se estruturam e tornam possível a leitura compreensiva.

Outro aspecto a ser complementado incide na imitação como característica marcante do processo de leiturização, especificada pela construção e desenvolvimento cognitivo do sujeito leitor, visto que não existe a possibilidade de originalidade, inventividade e criatividade sem meios efetivos da influência da representação dos elementos constitutivos da realidade.

Na visão de Ferreiro (2001), os alunos adquirem experiências providas de significados na vida contextual, como o interesse, atenção e:

Se pensarmos que a criança aprende só quando é submetida a um ensino sistemático, e que a sua ignorância está garantida até que receba tal tipo de ensino, nada poderemos enxergar. Mas se pensarmos que as crianças são seres que ignoram que devem pedir permissão para começar a aprender, talvez comecemos a aceitar que podem saber, embora não tenha sido dada a elas a autorização institucional para tanto (FERREIRO, 2001, p. 17).

Além disso, a fim de considerar o papel educativo da escola frente à aprendizagem discente, deve-se preponderar a colaboração da família quanto aos estímulos propiciados para o enriquecimento da bagagem cultural das crianças em idade educacional.

\subsection{A leitura como forma de prazer para o aluno com Síndrome de Down}

Este tópico manterá as discussões a respeito da ação educativa pautada na leiturização, favorecendo o fortalecimento do indivíduo leitor e com vistas a abranger em especial o aluno com Síndrome de Down, que ingressa na escola a fim de ampliar as 
suas potencialidades de aprendizagem, levando-se em consideração as suas limitações e possibilidades cognitivas, neurológicas e biopsicossociais.

Neste enfoque, frisa-se anteriormente a respeito da imprescindibilidade da leitura para a aprendizagem escolar dos estudantes e também a incumbência docente para estabelecer as avaliações e critérios utilizados para contemplar os princípios de uma leitura agradável e destituída de obrigação, mas provida de interesses do leitor.

Adiante, constata-se que algumas escolas do país estão se adaptando aos preceitos de uma sociedade livre, equânime e democrática e vêm oportunizando o acesso escolar dos alunos com deficiência incluídos nas matrículas efetivas dos anos letivos, até porque os dispositivos legais os exigem. Neste horizonte, espera-se que sejam intensificadas nas formações dos professores as temáticas de qualidade da educação, que perpassa pelos princípios constitucionais, metodologias de trabalho e diversidade humana.

Com esta prerrogativa, ainda assim, apesar das dificuldades, alguns dos familiares dos alunos com Síndrome de Down os matricularam nas escolas regulares. Claro que alguns assuntos pertinentes como a formação docente e infraestrutura escolar poderiam ser priorizados, todavia são questões de ordem política e que merecem atenção durante as discussões dos candidatos que pleiteiam um cargo público para viabilizar as políticas de Estado.

De uma perspectiva centrada nos aspectos dificultadores, faz-se necessário compreender alguns percalços que se estabelecem para impedir a assimilação e o gosto pelo texto lido.

Neste contexto, as inferências de comunicação podem ser as causas para inadequação literária entre aluno especial e o docente, pois não há possibilidade de analisá-los separadamente. A estreita aproximação entre aluno (leitor) e texto (ideias do autor) ressalta a iniciativa de se considerar alguns fatores como ruídos, deficiência intelectual ou distração, entre outros, para enfatizar o motivo da incompreensão.

A maneira pela qual os indivíduos expõem e processam mentalmente as ideias e conceitos de um texto sem alterar a verossimilhança das informações armazenadas produzem a inferência, que é uma estratégia utilizada pelos alunos, desde que se tenham muitas experiências linguísticas e comunicacionais.

O processo de desenvolvimento da criança com Síndrome de Down pode ser favorecido caso sejam empregados pela escola estímulos precoces inerentes às 
habilidades cognitivas de estruturação do pensamento, haja vista a possibilidade de estímulos precoces inerentes às habilidades cognitivas de estruturação do pensamento.

Em conformidade com algumas teorias psicopedagógicas para 0 desenvolvimento integral dos alunos que apresentem ou não Síndrome de Down durante as aulas de leitura com base nas temáticas comuns a cada realidade escolar, podem-se ensejar práticas que valorizem a elaboração de perguntas, porque é um recurso educativo e, se utilizado de forma correta, pode ser incontestavelmente eficiente.

Porém, é necessário saber quais as perguntas importantes a serem questionadas e abordadas, quais as informações que o texto enfocado deixa implícitas e/ou explícitas e quais os saberes dos signos linguísticos estão internalizados pelos alunos sobre o tema, com vistas a diferenciar o foco da pesquisa para o educando com Síndrome de Down e outros estudantes com deficiências das mais diversas.

$\mathrm{Na}$ proposta da intervenção com base na conceituação dos conhecimentos prévios existe a necessidade do entrelaçamento dos saberes do aluno com as informações proferidas pelo docente, com o objetivo de se averiguar quais os esquemas psicológicos e de interpretação utilizados nas situações-problema para atender às demandas do educador.

Em uma aula participativa, dialógica e interativa, o aluno também poderá valerse de uma técnica que, orientada adequadamente pelo docente, viabiliza um momento de trocas de ideias e vivências entre todos os educandos. Cita-se nesta etapa a auto explicação, que consiste no amadurecimento do estudante enquanto leitor que desvela progressivamente conceito autoral ou idiossincrático e em conformidade com as suas limitações cognitivas. Assim sendo, na exposição do que sabe, o aluno responde às perguntas inferenciais realizadas pelo professor.

Por conseguinte, o sucesso na proposição das atitudes favoráveis à consecução dos objetivos atrelados aos princípios da educação inclusiva e transformadora poderá ser efetivado na medida em que as aulas sejam atrativas, prazerosas e significativas para todos os alunos, indistintamente, com vazão para o proveito dos docentes na operacionalização dos métodos, técnicas, currículos e procedimentos didáticopedagógicos.

Por meio de abordagens constituídas de estudos e pesquisas nos campos da pedagogia, psicologia e neurologia, existe o balizamento das prerrogativas teóricas que propõem a leitura enquanto método de trabalho educativo que perpassa todas as 
disciplinas curriculares e áreas do conhecimento visto o seu potencial de integração entre diferentes culturas, percepções, ideologias e formas de se conceber a realidade.

Com este indício, a crescente preocupação em adotar os meios efetivos para incluir a leitura nos conteúdos específicos como recurso para ampliar e aperfeiçoar o desempenho dos alunos com e sem deficiência, em especial o caso especial do aluno com Síndrome de Down, objetivo principal deste trabalho científico, têm instigado a mobilização das instituições educacionais para a concretização dos ideais de leiturização para todos os educandos.

A capacidade de compreensão de ideias dos educandos com Síndrome de Down deve ser fortalecida e as escolas necessitam formular as ações eficazes para o respeito à diversidade humana e as Diretrizes Curriculares para a Educação Especial (2001) elucidam consideravelmente que:

A vida humana ganha uma riqueza se é construída e experimentada tomando como referência o princípio da dignidade. Segundo esse princípio, toda e qualquer pessoa é digna e merecedora do respeito de seus semelhantes e tem o direito a boas condições de vida e à oportunidade de realizar seus projetos (BRASIL, 2001, p. 24).

No bojo do entendimento, essa perspectiva de educação engloba a busca incessante e meticulosamente compromissada por parte dos educadores, coordenação, pais, comunidade escolar e alunos que participam direta ou indiretamente do processo ensino e aprendizagem, contribuindo para a formação holística do corpo estudantil, pois a sociedade contemporânea se torna permeada da complexidade humana, as atribuições e responsabilidades sociais exigem habilidades, capacidades e competências diversificadas e, portanto, a aprendizagem acontece ininterruptamente nos contextos de vida das pessoas, sejam espaços escolares ou não escolares.

\section{UMA BREVE HISTÓRIA: SITUANDO A SÍNDROME DE DOWN}

\subsection{O conceito de deficiência segundo a ordem social}

Para explicar a respeito do acesso à escola do aluno com Síndrome de Down, devem-se mencionar os aspectos jurídicos que promoveram o debate em nível nacional 
da inclusão das pessoas com deficiência em todos os segmentos da sociedade (escola, trabalho e vida social).

Historicamente, as pessoas que nasciam com alguma deficiência intelectual, visual, auditiva, distúrbios de comportamento e/ou física, tornavam-se um empecilho e motivo de segregação para as suas famílias, devido à padronização social e visão de mundo dos indivíduos, influenciado pelo estereótipo do que era ideal e aceitável na comunidade.

Após a consolidação de algumas vertentes, como a que definia a deficiência sob a ótica da visão médico-pedagógica, houve a integração dos indivíduos com deficiência nas escolas especiais, a fim de que se proporcionasse uma educação diferenciada do ensino aplicado nas outras unidades escolares.

Com o passar do tempo, as mobilizações advindas da sociedade civil solicitaram mudanças nas formas de se enxergar a pessoa com deficiência, sobretudo porque é um cidadão com direitos e deveres.

O grande eixo norteador centrou-se na elaboração da Constituição Federal de 1988, que preceitua o atendimento preferencial do aluno com deficiência na rede regular de ensino, pois antes não havia a perspectiva legal da matrícula nas escolas públicas.

Assim sendo, a maneira pela qual os indivíduos compreendiam o fenômeno da inclusão educativa estava permeada pelos princípios de dignidade humana, igualdade e diversidade entre as pessoas, independentemente das condições e origens. Podemos ressaltar esta premissa por meio do Decreto $n^{0} 6949$ (2009) nesta afirmação:

Reconhecendo as valiosas contribuições existentes e potenciais das pessoas com deficiência ao bem-estar comum e à diversidade de suas comunidades, e que a promoção do pleno exercício, pelas pessoas com deficiência, de seus direitos humanos e liberdades fundamentais e de sua plena participação na sociedade resultará no fortalecimento de seu senso de pertencimento à sociedade e no significativo avanço do desenvolvimento humano, social e econômico da sociedade, bem como na erradicação da pobreza (BRASIL, 2009).

Por isso, é nesse contexto que as discussões, problematizações e apontamentos sobre acesso e permanência de todos os alunos da rede pública ensejam oportunidades de para aquisição de significado social, seja na compreensão de que a deficiência pode ser congênita ao indivíduo ou acompanhá-lo após uma tragédia ou acidente. Todavia, o acesso ao ensino pode encontrar entraves por várias ordens de impedimentos, 
influenciando de maneira categórica nos alunos com deficiência, sejam com Síndrome de Down e outras ainda desconhecidas por grande parte da população.

\section{CONSIDERAÇÕES FINAIS}

A sala de aula é um espaço formativo para brincar, contar diferentes histórias, desenhar, correr, divertir-se, ouvir os amigos, de escrever, de conhecer, de aprender novos conceitos da matemática, ciências, geografia, conviver com os outros, produzir novos conhecimentos e a preparação para o exercício consciente da cidadania.

Neste ensejo, são diversos os olhares possíveis na tentativa de apreender a complexidade do espaço humano e a implicação que a inclusão dos alunos com Síndrome de Down promove em professores, família, alunos e comunidade escolar.

Esta afirmação enfatiza o pensamento de que, quando é proposta uma ação eficiente, aposta-se em condições que de alguma forma, possibilitem ao sujeito cognoscente inserir-se no contexto da escola da forma como pode naquele momento, em conformidade com a sua maturidade neurofisiológica, respeitando seu tempo, espaço, peculiaridades e virtudes.

Nesse contexto, tantas experiências significativas acontecem na unidade educacional, docentes e alunos aprendem e ensinam, participando de uma envolvente e complexa rede de relações que perpassam as dimensões históricas, sociais, afetivas, econômicas, geográficas e culturais.

O trabalho pedagógico com o aluno com Síndrome de Down convida o professor a pensar em diferentes estratégias para aquisição da acessibilidade escolar, com adequação dos conteúdos previstos e estabelecidos no currículo de determinada rede de ensino e adaptação de materiais que proporcionem o estabelecimento de importância à proposição conteudinal abordada nas aulas.

Por isso, faz-se necessária a reflexão do educador e todos os profissionais da educação (Professor Regente, Professor Especialista, Professor do Atendimento Educacional Especializado, Coordenação Pedagógica, Direção e Supervisão Escolar, Diretoria de Ensino e família) a respeito da escola que se tem e como é possível concebê-la através de práticas que incentivem o desenvolvimento e a aprendizagem dos alunos com Síndrome de Down.

Desta forma, se o docente se abster do movimento permanente de reflexão e 
enfocar as ações didático-pedagógicas para uma inclusão que se preocupa unicamente em manter o discente dentro da sala de aula e associá-lo a um padrão estereotipado como os demais estudantes público-alvo da Educação Especial, haverá a consolidação de uma prerrogativa na qual se compreenderá que todos os alunos aprendem no mesmo tempo, de maneira uniforme e inexistem diferenças individuais na classe.

Adiante, há de se pensar na equiparação de oportunidades, levando em consideração os aspectos pedagógicos e psicológicos, a fim de considerar as ações docentes concatenadas ao conceito de igualdade para todos os alunos aprenderem. Todavia, ao abordarmos esta equidade, devemos priorizar distinções entre as condições iguais para aprender que todos os cidadãos indistintamente terão acesso e as condições para aprender conceitos essencialmente relevantes ao pleno desenvolvimento da sociabilidade.

Entende-se que, para todos os discentes devem ser oferecidas condições de sucesso, permanência e educação de qualidade em consonância dos objetivos que a sociedade legitima para a formação de uma pessoa flexível, ativa, criativa, inovadora e com tendência às relações interpessoais.

As reflexões sobre os diversos olhares que mantém interface com as práticas sociais que visam intervir na formação do aluno com Síndrome de Down, têm o sentido de analisar as possibilidades e limitações que estas proposições oriundas da diversidade humana ensejam.

Na medida do possível, apresentá-las por intermédio das situações concretas que acontecem na realidade escolar, pontua o ponto de vista de que a ação e o pensamento são inseparáveis na produção do conhecimento. A análise, reflexão e a leitura averiguada durante a elaboração do texto, ganham consistência quando lidos à luz das contribuições dos teóricos da educação pelos docentes que necessitam revisar os saberes com os quais diariamente.

Inquestionavelmente, o princípio da educação inclusiva deve considerar a pedagogia da diversidade, que respeite gênero, raça, nível socioeconômico e às pessoas com deficiência se exige a consciência e muito esforço de cada segmento social (professores, mães, pais, comunidades e dirigentes) para que as pessoas tenham seus direitos respeitados, assim como a diversidade humana.

Portanto, a inclusão educacional do aluno com deficiência na educação infantil e ensino fundamental, preferencialmente na rede regular de ensino e na escola especial 
precisa focar estes eixos para uma prerrogativa efetiva: o educando e a interação com os demais alunos e os profissionais da escola, o aluno, os materiais pedagógicos, metodologias, avaliação e o processo de ensino e aprendizagem, suas possibilidades e limitações, a escola, seus profissionais e a inclusão, a família, a sociedade civil e a necessidade do acompanhamento clínico especializado no tocante aos aspectos comportamentos, fonoaudiológicos, cognitivos e físicos.

\section{REFERÊNCIAS}

BRASIL. Ministério da Educação. Diretrizes Nacionais para a Educação Especial na Educação Básica. Brasília, MEC/Secretaria de Educação Especial, 2001. Disponível em: http://portal.mec.gov.br/seesp/arquivos/pdf/diretrizes.pdf

BRASIL. Congresso Nacional. Decreto 6.949, de 25 de agosto de 2009. Disponível em www.planalto.gov.br. Acesso em 01 de setembro de 2011.

FERREIRO, E. Reflexões sobre alfabetização. São Paulo: Cortez, 2001

FREIRE, P. Ação cultural para a liberdade e outros escritos. São Paulo: Paz e Terra, 2001. 
DESAFIOS DA DIREÇÃO ESCOLAR NA PANDEMIA DA COVID/19:

UMA EXPERIÊNCIA NA REDE MUNICIPAL DE SÃO PAULO

\author{
CHALLENGES OF SCHOOL DIRECTORS IN THE COVID/19 PANDEMIC: \\ AN EXPERIENCE IN THE SÃO PAULO MUNICIPAL NETWORK
}

Izolda Maria Batista ${ }^{3}$

\title{
RESUMO
}

Este estudo é fruto do trabalho realizado pela gestão de um Centro de Educação Infantil do município de São Paulo, no ano de 2020. Tem como objetivo principal apresentar aspectos da experiência do trabalho da direção num ano em que se viveu a triste realidade de ter que enfrentar a PANDEMIA da COVID-19, situação que assolou o mundo todo, com perdas as mais diversas. Diante desse cenário, foi preciso reorganizar toda estrutura educacional para o formato presencial com equipe reduzida, virtual e a distância, a partir das determinações do Decreto $n^{\circ}$ 59.283, de 16 de março de 2020, com orientações a respeito do trabalho educacional da rede, durante a pandemia, seguindo as orientações da saúde. As ações foram várias: antecipação do recesso para equipe docente, alterações no calendário e no planejamento realizado no início do ano letivo. Durante as duas semanas de recesso da equipe docente, o trio composto por Diretor, Assistente de Direção e Coordenação Pedagógica buscou construir um formato e uma série de ações para a sequência do trabalho, parte no modelo remoto e outra no presencial, com escalonamentos, e número reduzido de servidores na unidade. No que tange à construção das experiências pedagógicas a serem realizadas com as crianças, um grande desafio, visto que a educação infantil se dá nas interações. Nesse sentido, a parceria com as famílias foi imprescindível para a manutenção dos vínculos. A metodologia de trabalho se valeu do uso de questionários, diálogos via telefone, reuniões online e, para questões muito pontuais, presencialmente. Foi o jeito de realizar o trabalho de gestão, buscando ao máximo a autonomia, ainda que numa conjuntura desfavorável. Esse estudo tem como base: a legislação vigente e os teóricos e pesquisadores, Licínio Lima (2011), Falk (2011), Vygotsky (2016), Rinaldi (2018), Paro (2018), Marin (2019), Freire (1996), Bourdieu (2018).

Palavras-Chave: Gestão escolar. Educação infantil. Pandemia - Transição. Políticas Públicas.

\footnotetext{
${ }^{3}$ Doutoranda pelo Programa de Pós-graduação Educação: História, Política, Sociedade da PUC/SP. Possui graduação em Pedagogia pelo Centro Universitário Fundação Santo André (2003). Mestrado em Educação: História, Política, Sociedade pela Pontifícia Universidade Católica de São Paulo - PUCSP (2017). Habilitação em Educação Especial e Orientação Pedagógica pela mesma faculdade. Especialização em Educação Infantil pela Universidade da Cidade de São Paulo - UNICID (2011). Pósgraduação em Educação Empreendedora pela Universidade Federal São João Del Rey- UFSJ (2011).
} 


\section{INTRODUÇÃO}

Este artigo é fruto de uma experiência do trabalho de gestão num Centro de Educação Infantil da rede direta Da Secretaria Municipal de Educação do Município de São Paulo, que atende crianças de zero a três anos, 11 meses e 29 dias, denominada primeira etapa da educação básica. Trata-se da escola e da educação pública.

A experiência aqui apresentada, dentre outros aspectos, busca tratar a transição ocorrida no ano de 2020, devido aos impactos e limites impostos pela Pandemia de Coronavírus, da COVID-19, doença infectocontagiosa de letalidade elevada. Isso impôs à escola o distanciamento social, tendo, no entanto, o cuidado de manter o vínculo entre instituição e famílias.

Essa situação acentuou as mazelas existentes na educação, que nos diferentes espaços e diversos profissionais, estudiosos e sociedade civil, já apontavam: o sucateamento da educação pública. Destacam-se aspectos da formação docente.

Enquanto as universidades não tiverem a coragem de assumir a sua função definida e definitiva de formar cada profissional separadamente - o professor da educação infantil, o professor das séries iniciais, os demais profissionais que atuam em atividades educativas - em muito mais tempo e densidade do que um ou dois semestres cada um deles, estaremos cada vez mais à mercê do ideário neoliberal e preso às ações de desmantelamento do pouco que resta da escola pública neste país (MARIN, 2019, p. 101).

Aqui são postas questões-chave para a gestão administrar num cenário desfavorável, pois muito foi demandado no tempo pandêmico para a realização do trabalho em novo formato. Se antes da pandemia já havia problemas, eles se acentuaram nesse período.

As questões da formação são só um recorte das mazelas, - existem tantas outras, desencadeadas por uma política neoliberal que procura sucatear a educação pública e transformá-la em mercadoria. As condições objetivas para a realização do trabalho a distância, tornou ainda mais precário o atendimento, ainda que resistindo e construindo diversas alternativas para a manutenção da presença do CEI na vida dos Bebês, das Crianças e das suas famílias. A estruturação das estruturas é um processo histórico. (BOURDIEU, 2018, p. 240). Não podemos perder de vista as bases, a construção anterior, pois ela muito nos ajudou na construção do formato imposto pela Pandemia da 
COVID 19. Trazendo Bourdieu para nos ajudar na compreensão de que as crianças e suas famílias não podiam ser vítimas de mais um momento de exclusão, o trabalho pedagógico e a presença da instituição educacional era princípio, que defendemos e fomos encontrando formas para tal realização e ação.

Esse trabalho tem as suas bases também em Bourdieu (2018) fundamentos para explicar aspectos das escolas, como também Vigotski (2016) para conceituar questões relacionadas ao desenvolvimento das crianças, e ainda em Licínio Lima (2011) se busca explicar a organização educacional, no campo mais da administração educacional, sem a preocupação de modelos de organização, ainda que a rede municipal imponha seu modo, por meio da legislação.

Interessa considerar modelos teóricos para o estudo da escola como organização educativa, possibilitando a sua descrição enquanto tal mas, sobretudo, permitindo a sua compreensão e interpretação (LIMA, 2011, p. 17).

Importa destacar de qual escola se está falando. Trata-se de um Centro de Educação Infantil, com todas as suas especificidades no trabalho pedagógico, com essa faixa etária. Para melhor ilustrar características dessa instituição, buscamos a experiência de Emmi Pikler.

[...] estabeleceu as condições pessoais e materiais de educação e as estruturas de organização internas cabíveis para que a criança educada nesse centro se sentisse competente em suas relações e atividades progressivamente enriquecidas; pudesse reconhecer-se no mundo material, nas relações com as pessoas do seu entorno imediato ou distante; respeitasse a si mesma e aos outros; estivesse aberta e preparada para aceitar novos conhecimentos; seguisse capaz de estabelecer relações afetivas duráveis e profundas e de integrar-se ativamente na sociedade (FALK, 2011, p. 29).

Toma-se como base, Paro (2018, p. 35) quando afirma que o processo de construção na educação não é feito por meio de transferência e sim "o educador propicia condições (ensino) para que o educando se aproprie (aprendizagem) da cultura".

Diante do cenário com tantos obstáculos, se fez ainda mais necessário ter esta concepção de educação como horizonte. Na educação infantil, isso se dá por meio de interações. No modelo a distância isso parece impossível. Para se tentar construir algo, contamos com a mediação das pessoas responsáveis pelos Bebês e as Crianças. 
A partir de março do mesmo ano, a Secretaria Municipal de Educação, decretou 'estado de calamidade'. Dentre as mudanças, a do calendário escolar, que determinou a antecipação do recesso para a equipe docente e trabalho remoto aos servidores acima de 60 anos, ou que tivessem doenças crônicas (como hipertensão, diabetes, os transplantados, os asmáticos, classificando-os como grupo de pessoas com comorbidades). Aos gestores e pessoal do quadro de apoio, que não faziam parte desse quadro, a normativa orientava trabalhar em esquema de rodízio, não ultrapassando cinco pessoas por dia no trabalho presencial na unidade. Dessas, quem da equipe gestora tivesse alguma comorbidade, deveria realizar o trabalho a distância.

O serviço de cozinha/alimentação, foi suspenso e os alimentos foram recolhidos nos primeiros dias de vigor do decreto, pela empresa responsável, "parceira" da Secretaria Municipal de Educação. "E praticamente nenhum direito social hoje, nem mesmo aqueles conquistados pelas lutas populares, é gerido sem a mediação de organizações privadas” (CATINI, 2019, p. 34).

Uma série de outras ações, que já tinham sido planejadas pela gestão com a equipe e as famílias, ficaram também suspensas, como parte das medidas para manter o distanciamento social e evitar contaminações, seguindo orientações da SME. O decreto $\mathrm{n}^{\circ} 59.283$, de 16 de março de 2020, apresentou, dentre outras, a seguinte orientação:

\begin{abstract}
Art. $3^{\mathbf{o}}$ - Os titulares dos órgãos da Administração Direta, Autarquias e Fundações, continentes de unidades de atendimento ao público, resguardada a manutenção integral dos serviços essenciais, deverão avaliar a possibilidade de suspensão, redução ou alteração dos serviços, implementação de novas condições e restrições temporárias na prestação e acesso, bem como outras medidas, considerando a natureza do serviço e no intuito de reduzir, no período de emergência, o fluxo e aglomeração de pessoas nos locais de atendimento, em especial das pessoas inseridas, segundo as autoridades de saúde e sanitária, no grupo de risco de maior probabilidade de desenvolvimento dos sintomas mais graves decorrentes da infecção pelo coronavírus (SÃO PAULO, 2020).
\end{abstract}

Diante desse cenário, foi necessário haver muito diálogo para construir um novo modelo de trabalho, buscando atender e agregar todas as pessoas da equipe. Sem contar com as preocupações com cada servidor (a), se tratando da situação nunca antes vivida, o enfrentamento a uma Pandemia de tamanha proporção.

Partiu-se dos princípios do Projeto Político Pedagógico da Unidade, que apresenta princípios claros a respeito do trabalho educacional com os bebês e as 
crianças. Com isso, o diálogo e a escuta, são pilares e condição básica, para qualquer ação da gestão.

Também foi necessária a construção pedagógica para chegar até as crianças e suas famílias, conforme já mencionado anteriormente, o cuidado com a manutenção dos vínculos. Alguns aspectos que se considera fundamentais foram fazer toda essa construção partindo da documentação, como os Decretos, Normativas e o Projeto Político Pedagógico/2020 da unidade, considerando os princípios da educação infantil na garantia dos direitos das mesmas ao que tange a educação. Com os conhecimentos acumulados pela equipe, era hora de ir além de cuidados e, tendo a solidariedade e a ideia de compartilhar como princípios, recorremos aos saberes de cada membro do grupo para construir alternativas a tal situação.

Além de toda a legislação que a rede municipal construiu ao longo dos anos, entre as quais: Os indicadores de Qualidade da Educação Infantil (2015), Padrões Básicos de Qualidade na Educação Infantil Paulistana (2015). O Plano Regional de Educação (2018), e a própria legislação federal estabelecida na Lei de Diretrizes e Bases Lei $n^{\circ}$ 9.394/96 tudo isso normatiza a Gestão Democrática. Nesse sentido, a base foi o PPP da unidade em 2020.

"Princípios e Concepções: O Projeto Político Pedagógico do CEI Suzana Campos Tauil está pautado na garantia dos direitos dos bebês e das crianças, dentre esses, destacam-se.

O projeto Político Pedagógico do CEI Suzana Campos Tauil está pautado na garantia dos direitos das crianças, com ênfase no direito de Brincar e de Viver a Infância em plenitude, destacando-se que a criança, durante o tempo em que estiver sob os nossos cuidados tenham a garantia dos seguintes direitos: Direito de ser feliz e acolhida por todos... (SÃO PAULO, 2020, p. 37)

São enormes os desafios postos a educação infantil num modelo de educação virtual, isso ficou evidente para toda comunidade educacional, estava claro para toda equipe, que mesmo com todo cuidado e esforço para se construir propostas de vivências significativas para os bebês e as crianças, os limites estavam postos. Nesse sentido, se fez necessário estabelecer intensamente o diálogo e o estudo na construção do novo formato de trabalho virtual para se fazer as construções pedagógicas.

Utilizou-se o recurso da aplicação de questionários, tanto para se obter informações a respeito das famílias, como para ouvir opiniões da equipe, com o objetivo de, ainda num cenário de distanciamento, promover a aproximação e ouvir todas as 
pessoas. Esse foi um dos princípios da gestão democrática, um dos meios de obter informações e construir o trabalho, considerando toda a comunidade educacional. Ainda que todas as interferências externas e imposições, nos esforçamos para encontrar brechas e ir tentando ser fiéis aos princípios democráticos.

Definiu-se que periodicamente se ligaria para as famílias, para saber notícias e dizer que no CEI, ainda que distantes, havia profissionais cuidando e se ocupando em realizar o trabalho educacional em prol dos bebês e das crianças. A instituição educacional tem um papel social em qualquer situação e, no caso apresentado, isso se acentuou. Os Bebês e as Crianças precisavam saber e sentir tal presença.

As devolutivas das famílias sempre soaram como alimento, indicando que era necessário permanecer com as práticas viáveis. Nas reuniões gerais, o tempo era destinado para compartilhar os acontecimentos do dia a dia na unidade e do fazer de cada pessoa da equipe, considerando que manter a unidade foi um dos objetivos centrais do trabalho, que não se realiza sem diálogo e comprometimento.

As demandas colocadas pela SME, nem sempre correspondiam à realidade da unidade, o que implicava buscar mediar, negociar e se pautar nos princípios da gestão democrática e seguir a legislação estabelecida no Projeto Político Pedagógico, além dos projetos educacionais construídos pela equipe e ir fazendo as devidas adequações. Considerando esse ambiente, o chamado "Chão da escola" nós conhecemos e estamos do lado da construção de uma educação pública, estabelecida na Constituição Federal de 1988, no Estatuto da Criança e do Adolescente de 1990.

A construção da administração por meio do "Trio Gestor", se deu com base no diálogo, na escuta e solidariedade, em não poupar esforços para buscar fazer o trabalho da melhor forma, com o princípio de que, se antes da pandemia já se buscava realizar o trabalho bom, naquele momento, era preciso fazer ainda melhor. Com a clareza da necessidade de uma pessoa aprender e se apoiar na outra.

O trabalho da direção ficou redobrado, implicava em administrar as demandas do trabalho presencial e a distância. A Diretoria Regional de Educação não alterou sua forma de cobrança, com prazos e o envio de documentação. A única alteração foi criar um malote e limitar as entregas presenciais de documentos na DRE, enquanto outras eram enviadas entregues virtualmente, ou por e-mail. Com as demandas feitas e enviadas on line as exigências de ampliaram- faltou compreensão para algumas resoluções, desconsideram a situação ímpar do momento, de situação nunca vivida antes. 
Nesse sentido, reafirmam-se as contradições e a falta de seguir as orientações da legislação. Em vários casos, fazer a interpretação da Lei de tal forma que atenda as necessidades impostas pela realidade.

Nesse sentido, a ideia era realizar um trabalho que possibilitasse dar segurança a toda comunidade escolar e buscar resolver sempre as demandas que surgiram, - e foram das mais diversas -, como também, a tomar as decisões de abertura da unidade educacional para atender num formato de oficinas, o que não era defendido para a educação infantil, levando a realização de muitos diálogos com o Conselho de Escola e toda equipe.

A questão era manter os princípios do PPP e o compromisso ético com toda comunidade escolar. Portanto, toda decisão ou encaminhamentos a serem realizados, refletiam-se nas condições objetivas e eram feitas tendo isso como norteador. A vida das pessoas era o principal e todo cuidado deve ser tomado para preservá-las.

O fazer da gestão necessita ter um olhar para aspectos mais amplos e entre eles está a implementação das políticas e adequações no campo micro, o zelo nas pequenas ações e encaminhamentos, tendo o humano como elemento principal. Construir educação exige ações complementares de educar e cuidar, mas cuidar não só dos alunos, mas também dos adultos que trabalham com elas, são práticas indissociáveis, no meu ponto de vista. Ainda que se crie esse conceito, os aspectos do campo do cuidar estão estreitamente relacionados com educar, numa construção de empatia e solidariedade. As tentativas no campo do micro, ainda que enfrentando todos os ataques impostos pelas políticas neoliberais que tentam nos engolir a cada instante. Vejamos o que nos fala a respeito, Catini.

\footnotetext{
O caráter conservador, e com elementos fascistas, das relações sociais atuais tende a ampliar o controle material e político da educação e, portanto, do trabalho educativo.

Se hoje tais relações sociais podem ser espelhadas em personificações do autoritarismo de figuras que chegaram ao poder, não é daí que elas germinaram. Antes, o cimento dessa fasticização se formou desde baixo, calcado na materialidade das relações sociais objetivas, e sua argamassa foi assentada por uma miríade de organizações sociais que passaram a compor um Estado ampliado (CATINI, 2019, p. 33).
}

Fazer o enfrentamento a estas práticas tão amplas e com o peso dos interesses econômicos, nos impõe buscar os pares e o fortalecimento no fazer educacional que acreditamos, dentre tantas outras bases alimentadoras no cotidiano como a construção 
com toda comunidade educacional, ainda que pareça pouco, foi o que me deu sustentação para fazer os enfrentamentos e realizar o trabalho aproximado do que compreendemos na educação de bebês e crianças para o seu desenvolvimento, autonomia e significativos nessa etapa.

O trabalho no formato a distância implicou ainda mais a busca da parceria com as famílias, sem o adulto fazendo a mediação com os bebês e as crianças, jamais se conseguiria realizar qualquer ação que chegasse às crianças.

\section{A RELAÇÃO COM AS FAMÍLIAS}

Como já apresentado anteriormente, manteve-se um diálogo constante, com as famílias e toda a comunidade escolar. E cada membro da equipe se responsabilizava por contribuir nesse trabalho. As professoras, as Auxiliares Técnicas de Educação, a partir do contato com as famílias repassavam suas demandas para a equipe gestora, que buscava fazer os devidos encaminhamentos.

As reuniões periódicas foram mantidas e surtiram efeito, sendo esse um momento de escuta, ainda que muitas famílias não conseguissem participar devido a condições objetivas, pela falta de acesso tecnológico, de tempo, e devido a suas cargas de trabalho redobradas, dentre outros motivos.

As reuniões de Conselho Escolar cumpriram um papel fundamental, mantendo princípios da Gestão Democrática, assim como a Associação de Pais e Mestres. Ainda que as reuniões tenham ocorrido no modo virtual, pela Plataforma do Google Meet, foi possível realizar as discussões e fazer os encaminhamentos necessários. As famílias que participaram, se responsabilizarão por informar no grupo geral de WhatsApp as demais que não participaram. Cabe destacar, o esforço principalmente dos membros do Conselho de escola para manter toda comunidade educacional informada, ainda que muitas vezes as informações eram passadas pelos representantes do poder público, primeiro a mídia e depois a escola. Esse sendo um marco negativo que dificultou em vários aspectos o trabalho educacional e a relação não só internamente como externamente, devido às várias compreensões a partir de uma mesma informação.

O trabalho tomou uma dimensão muito diferente de quando acontecia no presencial. Dois campos muito amplos e complexos de trabalho estavam postos. 


\section{O PRESENCIAL E O VIRTUAL}

A relação com a equipe, a comunicação e as preocupações com as pessoas: não se sabia como seria realizar um isolamento, já que nossa cultura valoriza o estar juntos. Ligações pontuais eram feitas para falar com as pessoas sobre como estavam, reforçando os cuidados e atenção. A princípio as pessoas vinham falar de trabalho, como se tivessem que dar explicações e falar de resultados. Aos poucos, foram entendendo que o trabalho era importante, mas que cada pessoa necessitava estar bem para o realizar e eram merecidos aquele telefonema e delicadeza, exclusivos naquele momento, na atenção para manter o vínculo.

Numa gestão democrática, um dos pilares que sustentam toda a grandeza da construção da educação, é ter a capacidade de transformar problemas em objeto de pesquisa,

É necessário quebrar o estereótipo de que a gestão é solitária, pois fica contraditório com o termo trio gestor, é preciso aprender a resolver as questões ouvindo os outros e acabar com o sentimento de que se é dona da verdade: é uma grande aprendizagem pedagógica, mais que isso, é uma postura ética.

Sempre há, também, a responsabilidade de provocar a equipe para compreender as dificuldades como grupo e buscar soluções coletivas.

Outra coisa importante foi e é a de trabalhar com todos, pois o vigia precisa se sentir parte do grupo e saber das coisas que ocorrem no ambiente escolar, pois ele/ela cuida de uma escola e esse não é um lugar qualquer.

É preciso ter coragem para fazer encaminhamentos e realizar o trabalho no cotidiano e que corresponda às necessidades do grupo, o que nem sempre está em consonância com as determinações da Legislação. Em Lima, quando :

[...] aparelho de controle central - uma máquina burocrática gigantesca que tudo pretende centralizar (nem que para tal seja forçada a desconcentrar), produtora de normativos que tudo contemplam e regulamentam até ao detalhe, uniformizadora e autocrítica (LIMA, 2011 p. 44).

Lidar com as intervenções externas e adequadas às demandas postas no cotidiano com as descrições e orientações das políticas, foi ainda maior o desafio, no contexto pandêmico. Nesse sentido, toda a organização sofreu de algum modo 
alterações, no entanto, mantivemos uma rotina já conhecida e vivida num cenário "normal" do trabalho pedagógico.

\section{A ORGANIZAÇÃO DAS REUNIÕES PEDAGÓGICAS}

As reuniões eram individuais quando necessário tratar de questões específicas, com aquela pessoa. Havia também reuniões em duplas com as professoras das salas, reunião por agrupamentos, e reunião geral envolvendo toda equipe.

Os objetivos distintos colocados em cada momento e os formatos demarcavam o que se pretendia. Por exemplo, reuniões com as duplas de professoras e auxiliares de cada turma específica, para tratar das questões de cada turma, planejar o trabalho, construir materiais, elaborar em conjunto estratégias para a continuidade do trabalho no virtual e que correspondem à realidade e às demandas de cada turma em cada momento.

As reuniões compunham um modelo, buscando contemplar as diversas situações, assim organizadas:

Reuniões com duplas de Professoras de cada turma, junto com as auxiliares de educação, as professoras readaptadas, buscando ajuda mútua, como também a realização da construção coletiva.

Em outros momentos houve reuniões com as professoras dos agrupamentos e demais membros da equipe, reforçar a unidade e a aproximação no planejamento das ações. Decidiu-se pela manutenção de uma reunião geral mensal, tratando de diversos temas. Dentre eles, os encaminhamentos realizados pela unidade durante o mês, sendo esse mais um momento de manter equipe informada a respeito das ocorrências da escola. Os casos específicos foram tratados no momento necessário.

As reuniões com a equipe de apoio e as professoras readaptadas, tratavam das questões específicas de seus trabalhos e se planejavam ações correspondentes às necessidades docentes e presencialmente eram tratadas as questões administrativas. Num cenário em que até o tempo da reunião se fazia necessário repensar, - pois existia desconforto em se participar de reuniões virtuais, com recursos de uso pessoal e todos os servidores assumindo os gastos, pois o poder público não se responsabilizou em criar as condições objetivas para a realização do trabalho. O que parecia ser condição dada a cada servidor de poder ficar em casa, lhe impunha a responsabilidade de criar suas condições e fazer o trabalho no formato online. Foi uma postura equivocada por parte 
da Secretaria Municipal de Educação e que acarretou prejuízos a muitos servidores, além do aumento da carga de trabalho.

\subsection{A organização para o envio das propostas de atividades/experiências para as crianças:}

Pensar a realização da educação infantil no presencial já é desafiador, pois a primeira infância é idade ímpar e que merece todo um jeito de fazer, considerando as especificidades de cada idade. Não é escolarizar a educação infantil pois, para isso, há um jeito de fazer próprio da educação para essa faixa etária. É importante destacar que essa modalidade da educação não é menos importante que as demais, já que os desafios colocados são dos maiores e ser professor (a) na educação infantil, exige grande dedicação e muito estudo. Valverde, em seu estudo sobre a rede municipal de educação de São Paulo, afirmou por meio da legislação vigente que:

Nesse sentido, várias ações foram desencadeadas no cumprimento dessas exigências legais, bem como na implementação de uma Pedagogia da Infância a qual implica considerar a criança, desde o nascimento, como produtora de conhecimento e cultura, a partir das múltiplas interações sociais e das relações que estabelece com o mundo, influenciando e sendo influenciada por ele, construindo significados a partir dele (SME/DOT, 2004, p. 6)

A partir da compreensão de toda essa complexidade e riqueza do trabalho com a primeira infância, o trabalho foi planejado considerando todos os detalhes, mesmo sabendo que a educação infantil é feita de interações. Entretanto manter um trabalho e um vínculo também nos remete as questões do desenvolvimento das crianças, elas ficaram sabendo do nosso trabalho ainda que a distância.

O que determina diretamente o desenvolvimento da psique de uma criança é a sua própria vida e o desenvolvimento dos processos reais desta vida - em outras palavras: o desenvolvimento da atividade da criança, quer a atividade aparente, quer a atividade interna. Mas seu desenvolvimento, por sua vez, depende de suas condições reais de vida (LEONTIEV, 2016, p. 59).

Esse formato foi utilizado para nos aproximar ainda mais das famílias, compartilhar com elas nosso modo de fazer. Esse caminho foi longo e exigiu esforço de 
cada pessoa da equipe, com elaborações também coletivas, em duplas, trios, e a busca por momentos de reflexão e formação.

Foram feitas postagens na plataforma definida pela Secretaria Municipal de Educação de São Paulo e também num grupo de WhatsApp de cada turma. Fomos melhorando o modo de fazer e aprendendo como de algum modo chegar até as crianças. Nesse sentido, as famílias foram fundamentais, no que tange à parceria com a unidade educacional, trazendo suas devolutivas e interações como um alimento, quando se reportavam a nós como instituição educacional.

Dedicamos tempo significativo no preparo e planejamento das vivências, considerando que nos demandaram novos conhecimentos e habilidades e, entre elas o manuseio das ferramentas tecnológicas como meio para realização do trabalho.

\section{CONSIDERAÇÕES FINAIS}

A realização do trabalho da gestão nesse período exigiu intensificação do diálogo, sensibilidade e cuidado, atenção redobrada nos mínimos detalhes, como também seguir as determinações da legislação, fazendo as devidas adequações, num cenário de muitas incertezas e falta de modelos e experiências com trabalho educacional em Pandemia dessa proporção. Nesse sentido, ficaram escancaradas as lacunas impostas pela situação, experiência nunca vivida antes. No entanto, com as mazelas acarretadas pelo modelo educacional pautado no lucro, este se apresentou ainda mais decadente nessa fase pandêmica. Vivemos a experiência de PANDEMIA de tamanha proporção, que rapidamente se alastrou por quase todos os países desse nosso mundo globalizado e que, no caso do Brasil, com o governo federal negacionista, o que agravou ainda mais o cenário e contribuiu para muitos óbitos.

No entanto, algo era muito claro para o Trio Gestor; havia as dificuldades impostas por uma política neoliberal, e dentro disso era necessário encontrar brechas para realizar o trabalho, sempre buscando colocar cada pessoa em primeiro lugar. Nesse sentido, foi muito importante seguir os princípios do Projeto Político Pedagógico e nos possibilitou não partir do zero. Ficou evidente: o que já era bem-feito, precisava ser ainda melhor, no sentido dos cuidados com os profissionais envolvidos e com toda comunidade. 
As dificuldades se evidenciam e foi necessário ampliar as ações para resolvê-las, tendo claro que muitas das situações vividas eram fruto de uma política neoliberal, que transforma educação em mercadoria e, nesse sentido, trata os trabalhadores como meros números, sem preocupação com o aspecto humano.

A respeito da produção pedagógica num cenário de muitas incertezas, as mais diversas, por exemplo, o que fazer com experiências pedagógicas para bebês e crianças? Considerando as especificidades do trabalho educacional com essa faixa etária, que só acontece por meio das interações? Era preciso manter a escola viva na vida dos bebês das crianças e de suas famílias. Alguns resultados - com dados concretos - apontam que foi possível manter o vínculo de algum modo.

Em reunião pedagógica, uma das mães disse: "eu senti e vi o trabalho do CEI no virtual. Me senti atendida, acolhida e isso me trouxe esperanças em vários momentos". (MÃE DE CRIANÇA DO BERÇÁRIO II, 2020). Um outro dado, foi a constatação de membros da equipe, que afirmaram ter sido esse um momento em que trabalhamos com mais leveza diante de todo o cenário imposto pelas condições objetivas do momento. "Eu senti o CEI acontecendo no virtual". (MÃE DE CRIANÇA DO BERÇÁRIO II, 2020).

Um fator determinante para a realização do trabalho nesse cenário tão desfavorável, foram as ações em conjunto do trio gestor. De fato, todas as ações eram planejadas coletivamente e se discutia cada detalhe. No entanto, muitas interferências externas contribuíram para a precarização do trabalho. Houve muitos momentos de exaustão e indignação por parte da equipe.

É importante destacar o quão estafante foi realizar o trabalho panorama que obrigava alguns a trabalharem no presencial e outros no virtual. A demanda de trabalho triplicou e com várias lacunas e sem respostas, houve a exigência de se resolver os problemas sem as devidas condições objetivas, dentre elas as ferramentas tecnológicas.

Para concluir, reforçamos a importância da compreensão de se utilizar para pesquisa e publicização o que se produz nas unidades educacionais e que possa servir para provocar outros a dar sequência ou mesmo fazer as devidas críticas. Isso também pode se constituir em ferramenta de luta, que denuncia as injustiças cometidas contra as crianças e todos os trabalhos da educação. Conforme o grande Paulo Freire afirma: "É impossível, na verdade, a neutralidade da educação.” (FREIRE, 1996, p. 124). 


\section{REFERÊNCIAS}

BOURDIEU, P. Conceitos fundamentais. Petrópolis, RJ: Vozes, 2018.

BRASIL. Congresso Nacional. Lei $\mathbf{n}^{0} 9.394$ de 20 de dezembro de 1996. Estabelece as diretrizes e bases da educação nacional. Brasilia, DF, 1996.

CATINI, C. Educação e empreendedorismo da barbárie. In: FERNANDO, C. (Org.) Educação contra a Barbárie: Por escolas democráticas e pela liberdade de ensinar. São Paulo: Ed. Boitempo, 2019.

FALK, J. "Lóczy" e sua história. In: FALK, J. (Org.). Educar os três primeiros anos: a experiência de Lóczy. 2. ed. Araraquara/SP: Junqueira\&Marin, 2011.

FREIRE, P. Pedagogia da Autonomia: saberes necessários à prática educativa, 6. ed. São Paulo: Paz e Terra, 1996.

LEONTIEV, A. N. Uma contribuição à teoria do desenvolvimento da Psique Infantil. 14. ed. São Paulo: Ícone, 2016.

LIMA, L. C. A escola como organização educativa: uma abordagem sociológica. São Paulo: Cortez, 2011.

MARIN, A. J. Textos de Alda Junqueira Marin. Araraquara [SP]: Junqueira\&Marin, 2019.

PARO, V. H. Professor: artesão ou operário? São Paulo: Cortez, 2018.

RINALDE, C. Diálogos com Reggio Emilia: escutar, investigar e aprender. 6. ed. - Rio de Janeiro/São Paulo: Paz e Terra, 2018.

SÃO PAUlO. MUNICÍPIO. Centro de Educação Infantil. Projeto Político Pedagógico. São Paulo, 2020.

Decreto no $^{\mathbf{5} 9.283}$ de 16 de março de 2020. (DOC..17/03/2020, pág. 1). Declara, situação de emergência no Município de São Paulo e define outras medidas para o enfrentamento da pandemia decorrente do coronavírus. SÃO PAULO, 2020.

SECRETARIA MUNICIPAL DE EDUCAÇÃO/DIRETORIA DE ORIENTAÇÃO TÉCNICA. caderno Temático de Formação II-Educação Infantil: Construindo a Pedagogia da Infância no Município de São Paulo. São Paulo:SME/ATP/DOT, 2004.

VIGOTSKI, L. S.; LURIA, A. R.; LEONTIEV, A. N. Linguagem, desenvolvimento e aprendizagem. 14. ed. São Paulo: Ícone, 2016. 
DE ALUN@PARA PROFESSOR@:

RITOS DE PASSAGEM NA CONSTRUÇÃO DA IDENTIDADE DOCENTE

FROM STUDENT TO TEACHER:

\section{RITES OF PASSAGE IN THE CONSTRUCTION OF THE TEACHER'S IDENTITY}

Cristina Leika Horii ${ }^{4}$

\section{RESUMO}

Neste texto analisei minha própria construção da identidade docente, através do conceito "Rito de Passagem" da Antropologia. Inicialmente cunhado na análise de outras culturas, para designar mudanças na posição social de um indivíduo. Especificamente sobre os futuros professores em formação, temos pesquisas como a de Katz (1968) e White (1989) comparando o período do estágio com o momento da liminaridade, proposto por Van Gennep (2011) como o momento em que os neófitos já separados do grupo, vivem um momento a parte da sociedade, para voltar a mesma em seguida. O trabalho de McNamora et al (2002) também segue nesta direção e traz contribuições interessantes ao focalizar a complexidade desse período, ressaltando a não linearidade do processo. Pesquisando sobre o início da carreira, na cidade de São Paulo, Ferreirinho $(2005,2009)$ retrata, neste sentido, os inúmeros recomeços para as profissionais neste período. O que me levou a análise do meu processo como um rito prolongado, que não se encerra nem com o final dos estágios, nem com a formatura; mas se delonga para os primeiros anos de carteira.

Palavras-chave: Rito de passagem. Identidade docente. Histórias de vida.

\section{INTRODUÇÃO}

Escrevo este texto faltando pouco mais de um mês para completar 35 anos. Na minha idade, muitas professoras (escrevo no feminino porque sabemos que elas são maioria na carreira docente) já têm mais de dez anos de sala de aula; o que seria de esperar de uma menina que entrou aos 17 na faculdade. Mas, não foi isso que aconteceu. Tive medo. Não me sentia bastante para ser professora. Este capítulo nasce de alguns

\footnotetext{
${ }^{4}$ Licenciada em Física e Pedagogia pela Universidade de São Paulo. Mestre em ensino de Ciências pelo Programa de Pós-Graduação Interunidades da mesma universidade. Especialização em Educação em Saúde no Atendimento Escolar Hospitalar: Modalidade Residência pela UNIFESP/GRAACC. Com experiência docente em Hospital Oncológico Pediátrico, na Educação Infantil paulistana e agora como coordenadora pedagógica na mesma rede.
} 
marcos, os quais considero ritos de passagem, desse meu processo de assunção da carreira docente.

\title{
2 O COMEÇO
}

\begin{abstract}
Estando com o giz balançando perfeitamente em seus dedos, e com um tom de voz e uma expressão facial apropriados, ela estava ensinando, insistindo com suas bonecas para prestarem atenção durante essa importante lição. Ela incorporou uma 'professora' apropriadamente (VAN FLEET, 1979 apud PAJARES, 1992, p. 322, tradução nossa).
\end{abstract}

Comumente, perguntamos às crianças o que elas querem ser quando crescer, e eu sempre respondi "professora", às vezes de Matemática, outras alfabetizadoras, para acabar cursando Licenciatura em Física, como minha primeira graduação. Sempre adorei brincar de escolinha, e eu incorporava a professora de tal forma, que deixava de ser um faz-de-conta para ser muito real. Eram lições reais. E o aprendizado também tinha que ser real.

Mas, em algum momento essa confiança se espairecerá.

Prestei vestibular. Passei. Cursei. Me formei... e não assumi. Era licenciada, mas não professora.

\section{O INÍCIO DA CARREIRA DOCENTE: UM MOMENTO CRÍTICO}

A primeira turma, a primeira vez que você entra e todos te olham. $\mathrm{O}$ coração bate como se estivéssemos correndo a maratona. Sentia a responsabilidade do mundo nas costas; tenho que 'dar conta'. Um medo. Ao mesmo tempo, a empolgação 'vou poder fazer os projetos que sempre quis'. Um misto dentro de mim, como se todas as cores, se emaranhavam dentro do peito.

A partir de vários estudos que propõem fases para a carreira docente, Jesus e Saul (2004) apresentam um estudo compilatório, apontando duas fases que são particularmente críticas:

$1^{\circ}$. Período crítico - entrada na carreira: pelo choque entre as expectativas e a realidade;

$2^{\text {o }}$. Período crítico - por volta de uma década, década e meia de trabalho: quando a profissão lhe torna rotineira, distanciando-se 
afetivamente de seus alunos, para buscar realização externamente a escola, também associada a crise de meia idade.

Sobre o momento de "Entrada na carreira", Michaël Huberman (2013) no texto "O ciclo da vida profissional dos professores", aponta dois aspectos como definidores desta fase: 'sobrevivência' e 'descoberta'. Aparentemente excludentes, a 'sobrevivência' traduz o período crítico, as dificuldades das mais variadas das questões relacionais, as inseguranças... A 'descoberta' traz o entusiasmo com o novo, aquele momento tão aguardado "a minha turma", ser professor, fazer parte deste grupo. Podem existir perfis em que predominam um aspecto sob o outro, é frequente a convivência entre eles, principalmente em que o segundo fortalece o primeiro.

De modo que por mais que a minha história seja única, angústias e entusiasmos são sentimentos comuns, na profissão docente.

Nos trabalhos de Viviane Ferreirinho (2005; 2009) a autora relata as dificuldades ao início da carreira também na realidade brasileira, especificamente na cidade de São Paulo, ressaltando os inúmeros recomeços neste período, seja pelas mudanças entre instituições particulares e destas, depois para a pública. E uma vez concursadas, demoram para se efetivarem em uma escola específica pulam de uma para outra, chamadas de escolas de passagem (geralmente situadas nas periferias, com maiores índices de violência). E mesmo em tais locais, costumam ficar com as turmas consideradas piores. A partir do conceito de 'campo' de Bourdieu, a autora desenvolve o espaço escolar, como possuidor de linguagens próprias e relações de poder, cabendo o novato desvendá-las, sozinho.

\section{RITOS DE PASSAGEM}

Foi pela tarde, umas $15 \mathrm{~h}$, na internet discada, que chiava ao se conectar, abri com lerdeza o site da FUVEST. E foi lá que encontrei o meu nome. Entre risos e lágrimas, amigos e familiares me pintavam e escreviam "bixete", "USP", "Física".

O que entendemos por rito? Ritual? Cerimonial? Será que temos espaço na sociedade atual para tais acontecimentos?

Mesmo que não tenhamos uma definição consensual entre os antropólogos, existe algo em comum entre os vários autores. Encontramos ritos em todas as sociedades porque somos seres semióticos, e necessitamos do processo de criação de 
símbolos (SEGALEN, 2000). Etimologicamente, Rito se refere a uma ordem já existente, algo que harmoniza as relações. Já as distinções entre rito, ritual e cerimonial são nebulosas (SEGALEN, 2000; RIVIÈRE, 1996).

Durkheim foi o primeiro a associar rito a religião, o que objetivamente significou como algo a ser analisado seriamente. Antecessores consideraram os ritos como meros fatos de superstição. A análise sociológica da Religião, por usa vez, revelaria como esta não só é produto da estrutura social, como parte importante da manutenção social. A religião e o rito constituiriam quase que uma oposição Teoria e Prática. A primeira seria a reflexão de uma meta-representação da sociedade. Enquanto rito seria a ação, como a sociedade se mostra, através das operações materiais. Como a técnica religiosa fundamenta-se na oposição religioso-profano; a partir das refreações dos prazeres, se protegeria o sagrado. De modo que, Durkheim associa o religioso ao coletivo, e o profano a posição individualista (MAISONNEUVE, 1996; CAZENEUVE, 1985).

A crítica que Levi-Strauss faz a teoria durkheiniana é a dependência ao suporte sócio-afetivo, que produziria estudos mentais coletivos e sentimentos comuns (MAISONNEUVE, 1996).

O rito, ao enunciar como deve-se comportar em relação do sagrado, estreita a relação do indivíduo com deus (que não é outro se não a própria sociedade). Na periodicidade do rito, recria-se o ser moral necessário para o seu funcionamento. Esta periodicidade organiza os tempos sociais entre tempos profanos e sagrados (MAISONNEUVE, 1996).

No dia do meu aniversário de 22 anos, foi também o da minha coleção de grau. De beca, eu e meus 20 e poucos colegas, adentramos o auditório, e caminhamos entre a plateia (formada por amigos e familiares) que aplaudia de pé. Discursamos. Pegamos o canudo. Juramos, como nos comportaríamos a partir do que nos foi ensinado. Pulamos em meio a chuva de confetes. $\mathrm{O}$ que seria o juramento se não uma forma de controle social? Recriamos o ser moral.

O folclorista Arnold Van Gennep foi o fundador da moderna etnologia francesa (RIVIÈRE, 1996), e talvez o primeiro a se dedicar especialmente aos ritos de passagem. Como Durkheim, Van Gennep buscava relacionar o rito com a estrutura social. Mas a metodologia usada por ele, foi considerada revolucionária, porque, ao invés de analisar 
pequenos momentos do rito, e comparar entre as diversas culturas, analisou o rito como um todo dentro da sociedade.

Van Gennep (2011) percebeu que havia certa ordem nos ritos de passagem:

$1^{\circ}$. Separação: Na ruptura com a sociedade, o sujeito passa por uma morte simbólica, para deixar de ser quem era.

$2^{\circ}$. Margem (liminar): Durante esse momento de transição, a parte da sociedade, ele vai aprender novos esquemas de pensamento, para uma nova maneira de ser.

$3^{\circ}$. Agregação: Como na separação ele passou por uma morte simbólica, na reintegração passa por uma ressurreição simbólica; numa cerimônia pública assume uma nova posição social (normalmente superior).

Esta divisão se tornou clássica para a análise dos Ritos de Passagem na Antropologia.

Não é uma sequência estagnada, pode ter variações entre elas; e a importância de uma das fases pode depender do rito. Por mais que durante o processo o ator passe por uma morte e ressurreição simbólica, a mudança é considerada mais do que metafórica, mas, real. Por isso que o rito é considerado eficaz para manter a ordem social. Não à toa, para manter a sociedade da maneira como está, os ritos têm como características: repetição, redundância e reafirmação.

No meu primeiro dia de estágio obrigatório para a disciplina de Metodologia do Ensino de Física, era a segunda ou terceira aula do dia, entrei e me sentei ao fundo em uma carteira vazia. Uma das alunas me disse "aluna nova, e já chegou atrasada?!", expliquei que era estagiária. Que lugar é esse? A licencianda. Você não é aluna, mas, ainda não é a professora.

Victor Turner se dedicou a uma das fases do rito de passagem: o liminar, que por ser um momento de transição, tem características específicas. Os liminares, pessoas em passagem, “(...) são necessariamente ambíguos, uma vez que esta condição e estas pessoas furtam-se ou escapam à rede de classificações que normalmente determinam a localização de estados e posições num espaço cultural” (TURNER, 2013, p. 98). Estão fora da estrutura, numa anti-estrutura. Estão entre, mortos no mundo dos vivos, não são mais o que eram, e ainda não são o que virão a ser depois do ritual. Geralmente os liminares precisam passar por provas, com perigos imaginários, com comportamento passível e humilde. São reduzidos, como que para esquecerem o que foram, para que aprendam novas habilidades que serão úteis para as novas responsabilidades que serão 
úteis para as novas responsabilidades, pós-ritual. Por isso, o rito tem um valor ontológico. O grupo que passa por essa experiência desenvolve uma certa camaradagem, às posições antigas não contam mais, são todos iguais, seres humanos totais. Em um relacionamento não estruturado que Turner denomina communitas. Essa oscilação entre estrutura (ordem rígida) e anti-estrutura (improviso, flexível) é como Turner concebe o processo que é a sociedade.

Rito e Identidade: Por mais que o rito revele as relações e condições, abre pouco espaço para redefinições, de modo que faz a manutenção da ordem social, com suas hierarquias e diferenças. Ora se o rito legitima a relação de forças, constrói propositalmente expectativas passiveis de serem realizada, na condição social do sujeito; quais seriam as expectativas depositadas nas professoras?

Identidade: "Quem sou eu?" talvez fosse uma pergunta “fácil” de responder há alguns séculos atrás, até mesmo óbvia. No entanto, ela vem se tornando cada vez mais perturbadora. Esta crise de identidade é consequência da mudança estrutural que sofre a sociedade, que com sua rigidez anterior fornecia também sólidas posições sociais para os indivíduos, passamos para um "duplo descolamento - descentração dos indivíduos tanto dos indivíduos tanto de seu lugar no mundo social e cultural quanto de si mesmo" (HALL, 2014, p. 10).

$\mathrm{Na}$ concepção sociológica, a identidade ocuparia a camada que envolve esse núcleo primário, mas comprimida pelo externo, ou seja, é uma camada entre o totalmente interno e o totalmente externo. No entanto, diferente do sujeito do iluminismo, não é imutável. Ao contrário, se modifica constantemente pelas pessoas que formam o 'grande' Outro. E na busca por agradar o Outro, desenvolvemos um grande 'poder' de ajustabilidade. Tão potente que 'compramos' os valores dessa estrutura externa, como se fossem originalmente nossos. Assim alinhamos "nossos sentimentos subjetivos com os lugares objetivos que ocupamos no mundo social e cultural" (HALL, 2014, p.11). No entanto, vivemos um momento (momento, porque são processos temporais, consequentemente históricos) em que essas estruturas internas não estão tão sólidas, junto com seus processos elas se deslocam e as identidades, sem clara referência externa, não nos oferecem o conforto anterior de saber qual o nosso papel objetivo na sociedade. Agora, multifacetadas, vivemos e convivemos com múltiplas identidades, às vezes contraditórias, muitas temporárias. 
As múltiplas identidades do sujeito são em pequena escala, o que é a sociedade pós-moderna com estrutura deslocada, sem um núcleo fixo, ou ainda com vários. De modo que, continuamente o sujeito está se organizando e reorganizando, com muitas descontinuidades no seu próprio interior. Com essa constante transformação dos espaços é difícil que cada indivíduo consiga dar sentido para sua experiência particular (HALL, 2014).

Identidade e Rito: O lado positivo da descentralização, é a flexibilidade para as novas identidades que se configuram ao redor dos novos centros, que estão se tornando mais privados porque cada um a personaliza, para o que lhe faz sentido. No entanto, Martine Segalen (2000) nos alerta que toda interpretação atualmente, depende apenas do próprio sujeito, de modo que "privam o indivíduo de um apoio coletivo, quer se trate de parentes ou vizinhos, e deixam-no, muitas vezes, na sua solidão íntima face a passagem do tempo" (p. 44) e as muitas posições sociais que o sujeito se vê exercendo, mas não conseguiu atribuir sentido.

Ritos de Passagem na Formação Docente: Já em 1968, Katz publicou um estudo intitulado "Rites of Passage and Teacher Training Processes" em que compara a formação do professor, especificamente o momento do estágio com o trabalho clássico de Van Gennep, sobre os ritos de passagem. Separação dos alunos para ir à escola. Transição (Margem), o estágio em si, em que os futuros professores relatam ter passado por humilhações, como também apontado pelo folclorista. Por fim, a Agregação, término do estágio, em que os neófitos são re-incorporados à sociedade.

Também White (1989) pesquisou a formação de professores, com base nas Teorias do Rito de Passagem. A autora mostra que após os estagiários começarem a se sentir confortáveis, também começam a refletir sobre a própria prática em comparação com a de seus colegas, buscando "o que funciona". A conclusão do estudo aponta para a necessidade de um aprendizado corporal para atuarem como professores.

Um estudo mais recente de McNamara et al (2002), abordou os ritos de passagem na formação inicial do contexto inglês, no momento em que o governo impôs o "Numeracy Skills Test" que junto com os outros testes, enviam mensagens conflituosas ao estudante e ao professor da universidade. Os autores propõem um modelo em que a fase de transição é não-linear, e formada por muitos entremeios, do ser estudante ao se tornar professor. 
A nossa experiência é de que a segunda (limiar) e a terceira (agregação) fases são de difícil distinção entre elas, mas que alguns são momentos importantes: o estágio obrigatório, auxiliar de classe (estágio remunerado), passar num concurso, ser a professora responsável da sala.

O meu primeiro dia como professora na Prefeitura de São Paulo, era uma segunda-feira, início do segundo semestre depois do recesso. Passei para o cargo de Educação Infantil, e por isso estava em um Centro de Educação Infantil (CEI), atendendo bebês e crianças entre 0 e 4 anos de idade. Logo descobri que uma professora não vinha, e deveria assumir seu lugar. E assim, me vi professora.

Identidade docente: O estudo de Oliveira et al (2006) sobre uma formação para profissionais já atuantes nas creches paulistanas, curso este que aconteceu em um momento histórico na educação da cidade, em que as creches migraram da Secretaria de Assistência Social para a Secretaria de Educação. Este movimento denota uma nova concepção de Educação Infantil, especialmente no atendimento das crianças de zero à quatro anos. Para além do cuidar, passou para a indissocialibilidade do educar e cuidar; como um direito da criança de se desenvolver globalmente, mais do que um direito da mãe trabalhadora. As autoras apontam mudanças significativas na prática e na concepção da prática, por parte das educadoras, dentre as quais: a consciência de uma intencionalidade educativa e por consequência a ressignificação no relacionamento com as crianças. Estas novas atitudes estão relacionadas à novas identidades.

[...] a construção da identidade é compreendida como um processo contínuo que ocorre no fluxo das atividades sociais. Mais do que instâncias estanques, as identidades precisam ser compreendidas dentro de relações carregadas de poder e, por isso mesmo, ser caracterizadas como relação de subordinação, cooperação ou competição, a depender do contexto e dos interlocutores. (OLIVEIRA et al, 2006, p. 553).

Percebemos assim uma forte relação da identidade docente e a experiência proporcionada no exercício prático da docência. Corroborando com as nossas entradas ao campo em que os docentes associaram em seus relatos o "sentir-se professora" com "ter uma sala" mesmo com as variações em relação a confiança e segurança em suas ações. Associaram também um aprendizado mais efetivo da profissão, a prática, ao aprender fazendo. O que nos levou a uma situação que nos parece paradoxal, entre as professoras que atuam na educação formal e ao mesmo tempo, questionam a 
importância desta categoria de formação. No entanto, neste artigo as autoras apontam a importância da qualificação formal para as educadoras gozarem do status, até então lhes negado, de professora, para muito além de cuidadora.

\section{CONSIDERAÇÕES FINAIS}

Passei por diversos ritos de passagem que marcaram minha multifacetada identidade. Para além de burocrática, cada rito marcou meu processo de assunção profissional. Me colocou sob diferentes olhares, que contribuíram para como eu mesma me vi e me constituí.

Se por um lado, legalmente o diploma é o que nos habilita a exercer a docência em escolas regulares. A palavra 'professora' é usada de forma muito mais ampla em nossa sociedade, a pessoa que sabe algo e ensina a sua comunidade, seja costura, futebol... por vezes, até banal. E por que relutei tanto?!

Paradoxalmente, cada rito me trouxe legalmente mais direitos, socialmente mais status; mas, dentro de mim, mais insegurança.

Como dizia Paulo Freire (1996, p. 107) "Ninguém vira autônomo para depois decidir", cada rito foi o exercício de me constituir. E confiante/consciente e que posso mais, sigo me constituindo.

\section{REFERÊNCIAS}

CAZENEUVE, J. Sociologia do Rito. Portugal: Rés-Editora, 1985.

FERREIRINHO, V. C. Práticas de Socialização de professores iniciantes na carreira, quem é o iniciante? 28 ${ }^{\text {a }}$ Reunião da ANPEd, 2005, Caxambu. Disponível em: http://28reuniao.anped.org.br/gt14.htm. Acesso em 29 de nov. 2015.

FERREIRINHO, V. C. Trajetórias de professores na carreira e percursos na cidade: estudo sobre a socialização de professores na carreira do magistério. Tese. São Paulo: Pontifícia Universidade Católica de São Paulo. 2009.

FREIRE, P. Pedagogia da autonomia: saberes necessários à prática educativa. São Paulo: Paz e Terra, 1996. (Coleção Leitura).

HALL, S. A identidade cultural na pós-modernidade. Rio de Janeiro: Lamparina, 2014. 
HUBERMAN, M. O ciclo de vida profissional dos professores. In: NÓVOA, A. (Org). Vidas de professores. Porto: Porto Editora, 2013.

JESUS, S.; SANTOS, J. Desenvolvimento Profissional e Motivação dos Professores. Educação, ano XXVII, n.1 (52), p.39-58, Jan./Abr. 2004. pp.39-58.

KATZ, F. E. Rites of Passage and Teacher Training Process. 1968. Disponível em: http://eric.ed.gov/?id=ED028125. Acesso em: 10 fev. 2016.

MAISONNEUVE, J. Os rituais. Portugal: Rés Editora, 1996. (Colecção Cultura Geral)

MCNAMARA, O.; ROBERTS, L.; BASIT, T.; BROWN, T. Rites of Passage in Initial Teacher Traning: ritual, performace, ordeal and Numeracy Skills Test. British

Educational Reasearch Journal, V. 28, N.6, 2002. p.863-878.

MORAES, R. Mergulhos discursivos: análise textual qualitativa entendida como processo integrado de aprender, comunicar e interferir em discursos. In: GAGLIASE MC, F. J.V. (Orgs.). Metodologias emergentes de pesquisa em educação ambiental. Ijuí: Ed Unijuí; 2005. p. 85-114.

OLIVEIRA, Z. de M. R. de O. et al. Construção da identidade docente: relatos de educadores de educação infantil. Cadernos de Pesquisa, v.36, n.129, p. 547-571, set./dez. 2006.

PAJARES, M. F. Teacher's Beliefs and Educational Research: Cleaning-up a messy construct, Review of Educational Research, v.62, n.3, p.307-32, 1992.

RIVIÈRE, C. Os rituais profanos. Petrópolis: Vozes, 1996.

SEGALEN, M. Ritos e Rituais. Portugal: Publicações Europa-América, 2000. (Coleção Saber).

TURNER, V. W. O processo ritual: estrutura e antiestrutura. 2. ed. Petrópolis: Vozes, 2013. (Coleção Antropologia).

VAN GENNEP, A. Os ritos de passagem: estudo sistemático dos ritos da porta e da soleira, da hospitalidade, da adoção, gravidez e parto, nascimento, infância, puberdade, iniciação, coroação, noivado, casamento, funerais, estações, etc. 2. ed. Petrópolis: Vozes, 2011. (Coleção Antropologia).

WHITE, J. J. Student Teaching as a Rite of Passage. Anthropology \& Education Quarterly., v. 20, p. 177-195, 1989. 


\title{
EXPERIÊNCIAS E PRÁTICAS DE UMA PROFESSORA INICIANTE: TERCEIRO ANO DO ENSINO FUNDAMENTAL EM FOCO EXPERIENCES AND PRACTICES OF A BEGINNER TEACHER: THIRD YEAR OF ELEMENTARY EDUCATION IN FOCUS
}

\author{
Fernanda Oliveira Costa Gomes ${ }^{5}$
}

\begin{abstract}
RESUMO
O presente artigo trata-se de um relato de experiência. A temática abordada se refere aos professores em início de carreira, suas descobertas profissionais e o sentimento de sobrevivência (ou choque da realidade). O objetivo deste trabalho consiste na discussão e reflexão em relação às experiências de uma professora em início de carreira em turmas do terceiro ano do ensino fundamental. As discussões serão embasadas teoricamente a partir dos estudos de Huberman (1992) que realizou um estudo sobre o ciclo de vida profissional dos professores, identificando em cada fase características próprias da profissão docente. Especificamente, serão utilizados, dos estudos de Huberman, os conceitos de descoberta e sobrevivência.
\end{abstract}

Palavras chave: Professores iniciantes. Relatos e Experiências. Terceiro ano do ensino fundamental 1. Descoberta. Choque da realidade.

\section{INTRODUÇÃO}

No presente artigo será apresentado um relato de experiência de uma professora iniciante, atuante no primeiro ciclo do ensino fundamental, na rede municipal da cidade de São Paulo. A temática aborda o início na profissão docente, enfatizando a fase de descoberta e a fase de sobrevivência, próprias do início de carreira.

O objetivo deste trabalho consiste em debater e refletir as experiências, desafios e ações de uma professora do ensino fundamental 1 no seu início de carreira.

Os conceitos de descoberta e sobrevivência, este último também conhecido como choque do real, foram desenvolvidos por Huberman (1992) e serão utilizados aqui para analisar e discutir teoricamente os dados apresentados.

Huberman (1992) realizou um estudo sobre o ciclo de vida profissional dos professores, onde identificou e conceituou fases recorrentes na vida profissional de

\footnotetext{
${ }^{5}$ Doutora e Mestre em Educação: História, Política, Sociedade pela Pontifícia Universidade Católica. PUC/SP. Especialista em Psicopedagogia e Graduada em Pedagogia. Atua como professora do primeiro ciclo do ensino fundamental na rede municipal de educação da cidade de São Paulo. Tem experiência como docente no ensino superior em cursos de Pedagogia.
} 
professores, desde o início de carreira até seu término. Particularmente, os estudos deste autor foram importantes na compreensão e no desenvolvimento das pesquisas, por mim realizadas, sobre a temática 'professores iniciantes' realizados em nível de mestrado, doutorado e estudos subsequentes.

$\mathrm{O}$ artigo está dividido em dois momentos, primeiramente será apresentado o relato da professora, descrevendo as suas memórias sobre o início na profissão, e em seguida, realizar-se-á uma discussão teórica sobre a temática com base nos relatos da professora.

\section{O INÍCIO DE CARREIRA: UMA EXPERIÊNCIA NO $3^{\circ}$ ANO DO ENSINO FUNDAMENTAL}

O texto a seguir é um relato escrito em primeira pessoa por se tratar de uma descrição pessoal sobre as vivências na profissão docente.

\section{- Escola 1: Indisciplina e violência}

O ano letivo de 2019 se iniciou com uma greve dos professores, que reivindicavam melhores condições de trabalho. Neste período estava em meu segundo ano como professora da rede pública da cidade de São Paulo. Recordo que optei por trabalhar na primeira semana e, na semana seguinte, decidi aderir à greve.

Eu não fazia ideia, mas tal decisão acarretaria consequências nas relações entre meus pares, pois de um lado, o grupo que aderiu a greve me acolheu e estabelecemos uma boa relação profissional, contudo, os professores que não aderiram à greve me tratavam com indiferença, parte deste segundo grupo se compunha, justamente, pelos professores do primeiro ciclo do ensino fundamental. Essa situação se estendeu durante todo o ano letivo, me fazendo viver no ambiente escolar uma situação de solidão.

Esse fator de socialização entre pares foi um dificultador a mais em todo processo de iniciação na profissão, entretanto, neste artigo, a ênfase se dará nas experiências vividas na ação da docência numa turma de terceiro ano do ensino fundamental I, no que se refere ao trabalho pedagógico com os alunos.

A turma do terceiro ano era composta por um grupo de 35 alunos, destes 35 apenas 5 estavam alfabetizados. Nesta turma, havia três alunos com deficiência, um 
deles com síndrome de down, e os outros dois eram autistas, sendo que um era calmo e dócil, enquanto o outro aluno se apresentava agressivo e agitado.

O trabalho com as crianças deficientes foi desafiador, mas ainda não era a maior dificuldade enfrentada naquela turma. Os casos de alunos com problemas de violência foi causador de situações em nível surreal. Eu me lembro do sentimento de sufocamento, desespero e de impotência.

Havia um aluno que desestruturava toda a organização da escola e esse aluno estava no terceiro ano, minha turma. Resumindo as ações desta criança podemos destacar, que embora fosse um menino de 8 anos de idade, ele não manifestava respeito por seus colegas, professores ou funcionários da escola.

A atitude desse aluno impressionava pelo grau de agressividade. Suas ações mais frequentes consistem em agressão física aos colegas, havendo circunstâncias de agressão a professores e funcionários, depredação de brinquedos e objetos da escola, ameaças contra professores e alunos da escola. A agressividade se manifestava tanto nas palavras quanto nas ações.

De fato, parecia um "caso perdido". Era angustiante conversar com aquele menino e não surtir efeito nenhum. Mas, um dia ele ficou tão nervoso que disparou a seguinte frase: "Eu já falei que eu quero morar com meu pai, porque eu não gosto da minha mãe. Eu estou falando e vocês não fazem nada" (ALUNO).

Naquele momento eu entendi, era um pedido de socorro. Conversamos com a mãe que admitiu viver em condições desfavoráveis, onde o menino presenciava uma realidade repleta de miséria, violência e tráfico de drogas. Tal situação parecia incomodar a criança que insistia não querer ficar com a mãe, manifestando o desejo de morar com seu pai. A mãe destacou que embora o menino citasse constantemente o pai, ele não o conhecia.

Na condição de professora, realizei diversos relatórios de desenvolvimento para encaminhar aos órgãos competentes, na esperança de que eles pudessem auxiliar de alguma forma, mas sem sucesso.

Insistia dia a dia, na convivência com aquela criança, comecei a colocá-la próximo a minha mesa e ali o orientava em atividades de alfabetização. No decorrer do ano fui aprendendo a lidar com aquela criança. Ele já não saia sem permissão, o que para ele era comum. Já não batia em seus colegas com frequência. 
Houve um dia em que ele perguntou: "Professora. Nós vamos sair de férias. Quando voltar às aulas, você vai estar aqui? Eu vou voltar para sua turma?” (ALUNO).

Ele se referia às férias do mês de Julho, portanto, a resposta era positiva. Expliquei que durante todo aquele ano eu seria a professora da turma, entretanto, no ano seguinte não saberia dizer.

E ele me respondeu: “Ainda bem! Porque já me acostumei nesta escola e com você" (ALUNO).

Naquele momento eu senti um acalento, uma esperança, já era possível perceber alguns avanços nas ações dele.

Aquele aluno estava imerso numa situação surreal, e isso era perceptível, mas existem situações em que a escola tem poder limitado e restrito. Considerando a situação de extrema vulnerabilidade, econômica, social, psicológica daquele menino, o trabalho realizado foi surtindo um efeito a partir da convivência, das conversas onde repetidamente apresentamos as regras, e apoio pedagógico ao educando. O resultado não o levou a perfeição, mas houve uma mudança significativa em seu comportamento.

Esse era o caso mais difícil na turma do terceiro ano, mas não era o único. Naquela turma havia três crianças com deficiência. Um aluno com síndrome de down, que apresentava dificuldades na fala, usava fraldas e também apresentava traços de autismo. Arrastava e subia nas carteiras, se jogava no chão e não tinha percepção de situações de perigo. Os alunos autistas eram um o oposto do outro. Enquanto o primeiro era calmo, carinhoso e realizava todas as atividades, o segundo, era extremamente agressivo. A mãe deste aluno era presente e atenciosa, e conhecendo as reações da criança permanecia no lado de fora da sala, aguardando qualquer crise que pudesse acontecer.

Com relação aos alunos AEE, o grande auxílio vinha dos demais alunos, que sempre se disponibilizaram a ajudar. Sabe-se que nestes casos é imprescindível ter a presença de uma estagiária, ou estagiário, durante as aulas. Durante o ano, esse auxílio só chegou por volta do mês de agosto.

Essa turma era a típica turma com aglomerados de problemas. Agitada, falante ao extremo, de difícil comportamento, mas mesmo assim o trabalho realizado resultou em 27 alunos alfabetizados, leitores e capazes de interpretar, calcular e interagir entre as diferentes disciplinas escolares. Esse resultado foi fruto de atividades e correções na 
lousa, onde todos os alunos participavam, atividades de interpretação de texto, jogos, brincadeiras, exercícios de matemática cotidianamente.

Considerando de onde saímos e aonde chegamos, e considerando todos os percalços do trajeto, terminei aquele ano satisfeita com meu trabalho.

\section{- Escola 2: o início da profissão docente e educação especial}

No ano seguinte, 2020, fui trabalhar numa outra escola. Nesta nova escola me foi atribuída mais uma vez uma turma de terceiro ano.A característica desta turma consistia no distanciamento considerável entre o desenvolvimento dos alunos, pois grande parte dos alunos apresentava dificuldades no processo de aprendizado, e por outro lado existia uma pequena parcela do grupo que apresentavam um desenvolvimento acima da média.

O primeiro grupo de crianças estava numa fase pré-silábica com e sem valor. Isso significa que não estavam alfabetizados, apresentavam grandes dificuldades na execução das atividades e se dispersam facilmente. Já o segundo grupo consistia numa minoria alfabetizada, que escreviam fluentemente e utilizavam letras bastão e também cursiva, escreviam textos de aproximadamente 15 linhas, sabiam organizar as atividades no caderno e liam fluentemente.

A rede municipal da cidade de São Paulo, fundamenta-se na teoria da Psicogênese (FERREIRO; TEBEROSKY, 1986) para realizar a identificação do nível de aprendizagem dos alunos. Portanto, eram realizadas sondagens com a finalidade de avaliar o processo de alfabetização de acordo com as hipóteses de aprendizagens.

Nos primeiros dias de aula daquele ano identifiquei a situação, e seria uma experiência interessante. A turma era calma e percebi grandes possibilidades. Parecia bom demais para ser verdade.

Entretanto, nos dias seguintes conheci mais dois alunos, eram dois alunos AEE (Atendimento Educacional Especializado). O primeiro tinha um laudo de TDAH (Transtorno do déficit de atenção e hiperatividade), era agressivo, e sua agressividade consistia em atacar seus colegas e professores com socos e chutes. Com relação a esse aluno, se algo o incomodasse ele partia para agressões físicas a toda e qualquer pessoa que se aproximasse. Já o segundo aluno era um caso mais delicado, segundo a mãe, o menino apresentava um problema neurológico onde apresentava um retrocesso mental 
(descrição da mãe do aluno). Esse aluno cuspia nos professores e nos colegas de sala, corria todo tempo, gritava, batia a cabeça na parede, jogava água nas paredes, e em situações extremas agredia fisicamente seus colegas.

A grande dificuldade nesta turma era manter o primeiro calmo e conter a agitação do segundo, pois do contrário seria impossível ministrar aulas para o terceiro ano.

$\mathrm{Na}$ escola havia um grupo de professoras que auxiliavam e substituem professores quando necessário. Eram três professoras e elas faziam revezamento para me ajudar em sala de aula. As professoras permaneciam com o aluno mais agitado, enquanto o outro permanecia próximo a mim.

Houve dias em que as professoras auxiliares precisaram substituir outros professores em outras turmas, nestes dias era praticamente impossível a realização do trabalho. Em um destes casos fiquei no fundo da sala com um dos alunos. Mas, o outro se irritou com um dos colegas e começou a agredir seus colegas. Fui separar a briga e com isso o outro aluno começou a correr pela sala, gritando, cuspindo e jogando os materiais dos colegas pelo chão.

O sentimento único exaustão, frustração e desânimo. O cansaço não era somente mental, era físico também, porque para conter o aluno agressor era preciso abraçá-lo e afastá-lo dos demais alunos, na tentativa de proteger a integridade física dos demais.

A professora que trabalhava na sala ao lado percebendo a situação chamava a coordenação para auxiliar, porque nem mesmo para chamar ajuda não havia tempo, pois não era possível deixar os alunos na sala sozinhos e sofrendo agressão.

Em uma destas situações a própria diretora tentou acalmá-lo, mas sem sucesso, pois ele a agrediu com chutes e socos. Ao perceber que não seria possível acalmá-lo no ambiente da sala de aula, a diretora retirou o menino da sala. No caminho para a diretoria a professora de informática chamou o menino e ele correu para encontrá-la. Naquele dia a professora responsável pela sala de informática relatou que aquele aluno só se acalmava ao ser levado para a sala de informática. Ou seja, em todas as crises agressivas do aluno o recurso utilizado até o momento era levá-lo para a sala dos computadores.

Entretanto, comecei a perceber que o aluno teria identificado tal mecanismo e se utilizava de tal artifício para ir à sala de informática. A estratégia utilizada foi inverter a 
situação. Todo o dia, no início da aula, conversava aquele aluno e explicava que ele só iria à sala de computadores se comportasse bem, isso é, sem agredir seus colegas.

Gradativamente aquele aluno foi percebendo que teria que utilizar de outros recursos para reagir às frustrações, e que, não mais poderia agredir seus colegas. A estratégia surtiu um resultado positivo.

$\mathrm{O}$ ano de 2020 foi um ano atípico, pois uma pandemia assolou o mundo e as aulas foram suspensas no início do mês de março. Posteriormente, as aulas retornaram de maneira remota, com a utilização de aulas online e plataformas virtuais.

O tempo que passei com essa turma foi consideravelmente curto, mas intenso.

Há um sentimento que prevaleceu nesta segunda experiência no terceiro ano e foi a exaustão. Havia em mim uma vontade e até um compromisso de fazer um trabalho de excelência, mas as condições eram surreais.

\section{DISCUSSÃO E REFLEXÃO}

O início de carreira na profissão docente é um momento de descobertas, de expectativas, de se sentir parte de um grupo profissional.

As pesquisas sobre o início de carreira apontam para um fato recorrente na vida profissional dos professores, fato este, que se remete a uma idealização da profíssão. Encontramos na literatura científica, dados que apresentam o entusiasmo dos professores iniciantes que almejam realizar um trabalho de excelência, de serem reconhecidos por seus colegas e também por alunos. Profissionais que saem dos cursos de graduação com ideias metodológicas para a sua atuação nas escolas, entretanto ao entrarem na escola começam a perceber e identificar os percalços, dificuldades e adversidades no percurso do trabalho.

Na pesquisa de Gomes (2014) tais fatores são percebidos, pois a pesquisa analisa os dados a partir das idealizações, frustrações e realizações na profissão docente. Nesta mesma pesquisa um dos professores pesquisados mencionou que idealizava a profissão a se imaginar como um "o professor", portanto seria um professor que faria a diferença e que conseguiria executar todos os conhecimentos adquiridos, entretanto o professor se decepcionou com a realidade da escola. 
demais a prática, ficou um ponto de frustração da realidade e de meus limites como professor. Vamos ao longo dos anos de graduação aprendendo tanta teoria e desconstruindo tantos vícios de prática educativa, que idealizamos fazer tudo diferente, sermos "O professor". Acreditava, por mais que fosse crítico das dificuldades em dar aula, que iria fazer o diferencial em parte que o problema da educação pública era de professores pouco inovadores, e que isso tudo era uma idealização, culpa em parte, inclusive, de algumas leituras feitas na graduação distanciadas da verdadeira educação, aquela que ocorre na sala de aula brasileira" (PROFESSOR ANDRÉ) (GOMES, 2014, p. 73)

Huberman (1992) conseguiu identificar que para cada fase na carreira existem características que se repetem na vida dos professores. Em sua pesquisa foi possível identificar que a maior parte do grupo de professores relatou passar por situações semelhantes.

Para o autor as fases no ciclo de vida dos professores são:

- O início na carreira docente

- Fase de estabilização

- Fase de pôr-se em questão

- Fase de serenidade ou distanciamento

- Desinvestimento (sereno ou amargo)

Os conceitos do referido autor, que serão utilizados aqui, são referentes ao início de carreira, mas àqueles que se interessarem por tal assunto vale a leitura completa do trabalho de Huberman. No tópico a seguir aprofundar-se-á a discussão sobre os conceitos de descoberta e sobrevivência (choque do real).

\section{DESCOBERTAS E SOBREVIVÊNCIA (CHOQUE DO REAL)}

Com relação ao início na carreira docente, Huberman (1992) identifica as fases de descoberta e sobrevivência como fases recorrentes na vida profissional de professores. O conceito de descoberta se refere ao "entusiasmo inicial, a experimentação, a exaltação por estar, finalmente, em situação de responsabilidade (ter a sua sala de aula, os seus alunos, o seu programa), por se sentir colega num determinado corpo profissional" (HUBERMAN, 1992, p. 39).

Já o aspecto da sobrevivência é traduzido pelo autor como "Choque do real", que consiste: 
na confrontação inicial com a complexidade da situação profissional: o tatear constante, a preocupação consigo próprio (Estou-me a aguentar?), a distância entre os ideais e as realidades quotidianas da sala de aula, a fragmentação do trabalho, a dificuldade em fazer face, simultaneamente, à relação pedagógica e à transmissão de conhecimentos, a oscilação entre relações demasiado íntimas e demasiado distantes, dificuldades com alunos que criam problemas, com material didático inadequado, etc. (HUBERMAN, 1992, p. 39).

A fase de descoberta é um momento em que os professores se encontram, geralmente, animados com o início da profissão, numa expectativa de aplicar seus conhecimentos e de se sentirem parte da comunidade e do grupo profissional. Fase esta, de inúmeras aprendizagens. Contudo, a profissão docente vem apresentando inúmeros desafios que desgastam o profissional e, em alguns casos, causa um sentimento de decepção e frustração que pode ser identificado como choque de realidade.

$\mathrm{O}$ relato de experiência apresentado no item anterior retrata este momento, ou seja, um momento em que a realidade não atendeu as expectativas da professora.

As situações vividas pelos professores no ambiente escolar são as mais diversas, e são permeadas pelos problemas sociais, culturais, econômicos, estruturais, e que, portanto, estão além do pedagógico. Mas, mesmo assim, grande parte dos professores buscam trabalhar da melhor forma possível para realizar um bom trabalho.

Esse movimento poderia ser comparado a um "remar contra maré", pois é desgastante, cansativo e muitas vezes solitário. Os estudos que fundamentam o trabalho docente auxiliaram a professora a resistir, a entender que o possível foi feito, entretanto é preciso que as instituições políticas, organizacionais também façam sua parte. Se um professor não tem essa consciência, poderá cair na ilusão de que é ele o incapaz, quando na verdade existem casos em que é necessária uma equipe inteira para encontrar solução.

A fase de descoberta foi para a professora iniciante uma fase de analisar, de compreender o lugar e as circunstâncias para então agir dentro do possível.

Pois, os problemas sociais como: os vários tipos de violência, a fome, a falta de habitação, a ausência de condições mínimas para uma vida digna alteram os cenários e lançam grandes desafios no trabalho dos professores. Portanto, o exercício de pensar, analisar e teorizar as práticas são essenciais no aperfeiçoamento da profissionalização do trabalho docente. E isso acontece desde o processo de formação inicial na graduação até a formação continuada que acontece no interior das escolas públicas nas reuniões de formação. 
Portanto, a fase de descoberta é um momento de descobrir a realidade da escola, seus desafios, as relações sociais que podem ajudar ou dificultar o processo, mas é também o momento de pôr em prática o conhecimento sobre a análise social, política e cultural na qual se vive, para então desenvolver estratégias de superação e resistência, compreendendo que o poder público também deve realizar sua parte neste processo, pois existem questões que vão além do pedagógico.

No que diz respeito à educação inclusiva não há dúvida que ela é necessária, importante, imprescindível na sociedade e na formação dos alunos. De todos os alunos, pois a presença em sala de aula dos alunos que apresentam alguma deficiência é importante não só para eles, mas é importante também para os demais alunos. Já que a convivência entre os diferentes leva a uma aprendizagem que não se ensina apenas com livros e tarefas, e sim, se ensina com o desenvolvimento e exercício do respeito, tolerância e empatia. Um aluno não-deficiente ao conviver com alunos AEE aprendem que todos temos capacidades. Capacidade de: fazer, agir, sentir, ajudar e contribuir para a sociedade.

Entretanto, para que este trabalho aconteça deveras efetivo são necessárias condições, materiais, pessoal, formação e reconhecimento profissional. Existem casos de escolas em que os professores não tem estagiários, materiais, estrutura para trabalhar com os alunos com necessidades especiais. Não há condições de um professor, de uma professora ensinar um grupo com mais de 30 alunos, sem nenhum auxílio pedagógico ativo, sem materiais adaptados.

Portanto, é necessário que a lei ${ }^{\circ} 13.146$ de julho de 2015 seja efetivamente cumprida.

Art. $8^{\circ}$ É dever do Estado, da sociedade e da família assegurar à pessoa com deficiência, com prioridade, a efetivação dos direitos referentes à vida, à saúde, à sexualidade, à paternidade e à maternidade, à alimentação, à habitação, à educação, à profissionalização, ao trabalho, à previdência social, à habilitação e à reabilitação, ao transporte, à acessibilidade, à cultura, ao desporto, ao turismo, ao lazer, à informação, à comunicação, aos avanços científicos e tecnológicos, à dignidade, ao respeito, à liberdade, à convivência familiar e comunitária, entre outros decorrentes da Constituição Federal, da Convenção sobre os Direitos das Pessoas com Deficiência e seu Protocolo Facultativo e das leis e de outras normas que garantam seu bem-estar pessoal, social e econômico (BRASIL, 2015). 
Destaco enfaticamente que, os alunos com deficiência NÃO atrapalham os demais alunos, NÃO atrapalham a escola pública ou particular, mas o que atrapalha é lançar toda a responsabilidade da inclusão sobre o ombro do professor. A inclusão deve ser pensada nas políticas educacionais, no momento da construção das escolas, na elaboração do material curricular, na elaboração dos instrumentos de avaliação; que não poderiam ser os mesmos utilizados com os demais alunos.

E seria importante destacar que para resistir e persistir no trabalho docente seria importante não se sentir só, o que infelizmente é muito comum. E para isso, seria preciso rever as políticas educacionais, para que a organização estrutural da escola, de fato, atenda as demandas e necessidades do processo de ensino e aprendizagem. Em outras palavras o professor é cobrado das mais diferentes atribuições, seria saudável que os responsáveis pela elaboração das políticas chamassem para si a responsabilidade do êxito ou fracasso da educação no Brasil.

Registro aqui minha manifestação para o fato de que queremos realizar nosso trabalho com excelência e comprometimento, entretanto precisamos de condições físicas, psíquicas, sociais e pedagógicas para realizá-las. Quero uma escola pública com ênfase verdadeiramente na formação integral do indivíduo e não apenas uma formação para o mercado de trabalho.

Se quisermos verdadeiramente que a educação alcance seu ápice democrático, levando as crianças, jovens e adolescentes ao acesso a uma educação integral, humana e completamente emancipatória é necessário ouvir o que têm a dizer os profissionais da educação, é necessário saber o que passam os professores nas salas de aula das escolas públicas deste país.

Ouvir a voz do professor devia ensinar-nos que o autobiográfico, "a vida", é de grande interesse quando os professores falam do seu trabalho. E, a um nível de senso comum, não considero surpreendente, se não francamente injusto, que durante tanto tempo os investigadores tenham considerado as narrativas dos professores como dados irrelevantes (GOODSON, 2013, p. 71).

Mas, a voz dos professores é uma voz que incomoda muita gente, mais especificamente àqueles que defendem o status quo desta sociedade desigual. Lawn (2001) afirmou que o professorado é uma classe que causa pânico no Estado, 
A existência de professores que não se adequam às identidades oficiais causam pânico. Da mesma forma, as ideias que os professores têm, e as pessoas às quais se associam, também causam pânico. A história do ensino em Inglaterra, anterior a 1920, sugere que o simples facto de os professores existirem enquanto "grupo numeroso" era suficiente para que fossem olhados com desconfiança pelos líderes políticos, não pelo que faziam, mas pelo que representavam. Historicamente, os professores eram vistos como um problema quando os guardiões do Estado sentiam que eles constituíam um grupo numeroso, um colectivo, fora do seu controle e que se tornavam demasiado laicos (i.e. perturbadores da ordem natural, devido simplesmente à sua existência!), ou quando expressavam, ainda que discretamente, opiniões acerca do seu trabalho de um modo que os seus empregadores consideravam provocador. Se a linguagem surgisse, de alguma forma, associada a um emergente movimento trabalhista, então o pânico e a análise crítica aumentavam. Geralmente, o que parecia de fato contar era a natureza simbólica das suas ações, não a realidade da ação, por si só. Era apenas o que os professores pareciam estar a fazer! A identidade é construída, quer contra, quer a favor de algo (LAWN, 2001, p. 123).

Embora não o tenha citado anteriormente, gostaria de citar como exemplo o professor, Paulo Freire. Ele foi um professor que incomodou tanto, que foi exilado, considerado um perigoso subversivo. Incomodou tanto, que mesmo após sua morte ele continua incomodando.

Incomoda por quê? Porque os professores que têm consciência de classe, que não são manipulados pelo sistema poderão formar pessoas capazes de analisar criticamente o sistema, e isso é perigo para quem pretende manter a estrutura atual da sociedade.

\section{CONSIDERAÇÕES FINAIS}

A área educacional é composta por uma complexidade tamanha. Existem muitas situações que vão se maquiando como naturais, e a consequência disso é o não questionamento. As experiências vividas pelos professores nas salas de aulas no Brasil precisam ser debatidas. É necessário registrar as experiências, as práticas e as manifestações dos professores, pois existem conhecimentos e debates necessários a se realizar.

Diariamente, existem professores que vivenciam situações surreais no ambiente escolar. E são vozes sufocadas, são histórias não contadas e que se perderão com o tempo. E por esse motivo, é que se fez necessário escrever este relato. 
A análise reflexiva teórica partindo da realidade das escolas é, certamente, um campo rico a ser explorado. E com este objetivo que se traz aqui a discussão acerca das vivências dos professores, para que modestamente, possamos aprofundar os debates, estudos e pesquisas sobre a realidade do trabalho docente.

O início de carreira é um momento em que, geralmente, os professores enfrentam as escolas de difícil acesso, com altos índices de violência e com as turmas mais difíceis. Em especial, a realidade brasileira faz com que o choque da realidade seja marcante no início de carreira dos professores. Seria preciso pensar também na inserção destes profissionais na escola, pois o sentimento de solidão é um dificultador na ação dos profissionais. Um grupo empático, profissionalmente unido pode amenizar os impactos da realidade sobre o iniciante. Temos que considerar que o bom trabalho de um professor também depende da saúde mental, psicológica e emocional dos mesmos, mas a realidade escolar somada a solidão, insegurança, e o sentimento de sobrevivência pode levar esse iniciante à exaustão.

\section{REFERÊNCIAS}

BRASIL. Congresso Nacional. Lei $n^{\circ} 13.146$, de 6 de julho de 2015. Institui a Lei Brasileira de Inclusão da pessoa com deficiência. Brasília, DF, 2015.

FERREIRO, E.; TEBEROSKY, A. Psicogênese da língua escrita. Porto Alegre: Artes Médicas, 1986.

GOMES, F. O. C. 2014. As dificuldades da profissão docente no início da carreira: Entre desconhecimentos, idealizações, frustrações e realizações. Dissertação (Mestrado em Educação: História, Política, Sociedade). São Paulo. Pontifícia Universidade Católica de São Paulo / Programa de Estudos Pós Graduados em Educação: História, Política, Sociedade.

GOODSON, I. F. Dar voz ao professor: As histórias de vida dos professores e o seu desenvolvimento profissional. In: NÓVOA, A. (Org). Vida de professores. Portugal: Porto Editora, 1992.

HUBERMAN, M. O ciclo de vida profissional dos professores. In: NÓVOA, A. (Org). Vida de professores. Portugal: Porto Editora.1992.

LAWN, M. Os Professores e a Fabricação de Identidades. Currículo sem Fronteiras, v.1, n.2, pp. 117-130, Jul/Dez 2001. 


\section{OS DESAFIOS DA PROFISSÃO DOCENTE: TRANSGRESSÕES E VIOLÊNCIA NA ESCOLA}

THE CHALLENGES OF THE TEACHING PROFESSION: TRANSGRESSIONS AND VIOLENCE AT SCHOOL

Elaine Aparecida Pereira ${ }^{6}$

\section{RESUMO}

Este artigo trata do relato de duas experiências envolvendo situações de transgressão (indisciplina) e violência em escolas de ensino fundamental da rede municipal de ensino de São Paulo. O objetivo do trabalho é analisar tais experiências com base no pensamento de autores que se dedicam à discussão desses temas e sua relação com o contexto social em que a escola está inserida, como Adorno, Charlot, Fanfani e Ianni. Os fenômenos da indisciplina e violência serão analisados a partir dos conceitos de violência na escola, violência à escola, transgressão, autoridade esclarecida e condescendência pedagógica.

Palavras-chave: Escola. Transgressão. Violência. Incivilidade.

\section{INTRODUÇÃO}

O início da vida profissional como docente nos impõe muitos dilemas e desafios, uma vez que a formação nos cursos de licenciatura, por melhor que seja, não é suficiente para prever ou se antecipar a todas as adversidades presentes no cotidiano escolar, e jamais poderia ser, uma vez que a realidade objetiva é sempre dinâmica e singular. Nesse sentido, o arcabouço teórico que norteia a prática docente é, na maioria das situações, um instrumento limitado que pode nos fazer compreender os múltiplos fatores que determinam um fenômeno, porém, não pode nos oferecer metodologias capazes de responder a todas as situações em sua complexidade, ou seja, não é possível oferecer fórmulas.

\footnotetext{
${ }^{6}$ Doutora e mestre em Educação: História, Política, Sociedade (área de concentração Educação e Ciências Sociais) com pesquisas sobre o tema das relações escolares e graduação em História pela Pontifícia Universidade Católica de São Paulo. Graduada em Ciências Sociais, pela Fundação Santo André. Cursou licenciatura em Pedagogia na Universidade Cidade de São Paulo. Atua como professora de História na educação básica, desde 2003, tem experiência em gestão escolar e leciona no ensino superior na área das licenciaturas.
} 
Para além das questões de aprendizagem, do ensino de certos conteúdos curriculares que envolvam também o planejamento e o desenvolvimento de estratégias de avaliação, o docente terá que ocupar-se de uma série de demandas que fazem parte de suas atribuições profissionais, como garantir um ambiente favorável à aprendizagem; mediar conflitos entre os alunos; dialogar com as famílias; desenvolver projetos em parceria com outros professores; participar efetivamente das decisões coletivas sobre questões pedagógicas e da organização escolar; e, nos casos em que são garantidas as condições para uma gestão democrática, compreender a realidade política, social e econômica em que a escola está inserida, entre outras.

Em todas as atribuições docentes está presente a questão das relações interpessoais, o que exige do profissional habilidades que são pouco discutidas na formação inicial. A relação entre professores e alunos é a principal delas. Como agir frente aos esperados e inevitáveis conflitos que permeiam o cotidiano de uma sala de aula? O que fazer diante das situações de indisciplina ou das cenas de incivilidade? Como atuar em episódios de violência? Essas são indagações que com frequência se impõem aos docentes logo nos primeiros dias de exercício da profissão.

Os procedimentos adotados pelo docente geralmente são orientados pela tendência presente na unidade escolar, que pode ser mais punitiva ou mais conciliatória, o impelindo a agir de forma irrefletida. Há também a possibilidade de que o docente tende a agir de forma a reproduzir o comportamento observado em seus próprios professores diante de tais situações ao longo de sua vida escolar. Isso ocorre porque, muitas vezes, o docente não encontra apoio nos colegas ou na equipe gestora, ou até mesmo evita tornar públicas as suas inseguranças por medo de julgamentos, pois existe uma concepção arraigada na escola de que o bom professor é aquele que "domina a sala", isto é, tem controle sobre a sua turma e não leva problemas para a direção.

Esses dilemas acompanharam a minha vida profissional desde os primeiros momentos em que estive em uma sala de aula como professora e, inclusive, tornaram-se tema da minha dissertação de mestrado. Dessa forma, este artigo tem por objetivo relatar duas experiências que vivi como professora de História no ensino fundamental, na rede municipal de ensino de São Paulo, envolvendo as questões de indisciplina e violência na escola, além de apresentar uma análise, entre tantas possíveis, sobre esses fenômenos à luz do pensamento dos seguintes autores: Adorno, Charlot, Fanfani e Ianni. 


\section{A PROFISSÃO DOCENTE}

Sempre adorei a figura do professor. Quando criança, logo nos primeiros anos de escolarização, era daquelas alunas chatas que ficava na porta da sala dos professores esperando a professora voltar do intervalo, só para caminhar ao seu lado até a sala de aula. Na segunda série, nos anos 1980, costumava visitar a minha professora em sua casa aos sábados. Ela morava em frente à escola e estava sempre fazendo faxina. Nunca deixou de me receber e sempre me oferecia um pedaço de chocolate branco, que nunca gostei muito, mas jamais recusei.

O hábito de conversar com os professores ao final da aula me acompanhou durante toda a minha trajetória como estudante, adorava saber sobre a vida de cada um deles e o que pensavam sobre o mundo. Claro que sempre tive as minhas preferências, mas, no geral, a figura de professor sempre me encantou.

Como aluna, convivi com professores de vários tipos, desde aqueles que ainda praticavam castigos físicos, como bater em nossas pernas com ripa de madeira e nos obrigar a fazer polichinelo carregando alguns livros em cada braço, até aqueles que nos orientavam a jamais pedir para ir ao banheiro, dizendo que deveríamos ser livres e agir com responsabilidade. Poderíamos sair da sala a qualquer momento sem dar satisfações, desde que nos responsabilizássemos pelos nossos atos, o que significava aceitar as consequências.

Essa experiência aconteceu na quarta série, logo após a redemocratização do país. Havia um clima de liberdade e entusiasmo no ar, não cantávamos mais o hino nacional, mas o hino da nossa escola, escrito por esses professores: “Juntos escalaremos a montanha do saber, juntos escalaremos o seu pico azul, nossos corações esperançosos sonham com um belo Brasil, justo, feliz e forte (...)", dizia a canção.

No ensino médio, conheci professores que haviam lutado contra a ditadura militar e sido perseguidos. Esse assunto me interessava muito e nossas conversas me incentivaram a reabrir o grêmio estudantil da escola junto com outros alunos. Nessa época eu já desejava ser professora e via a profissão como um instrumento para transformar o mundo. Inquieta frente às questões sociais, fui cursar Ciências Sociais. Depois de formada, diante das dificuldades de conseguir aulas de sociologia, resolvi cursar História. 
Entrei em uma sala de aula como professora pela primeira vez em 2003. Junto comigo entraram todos os meus professores, impregnados em minha memória afetiva, a minha expectativa de que ali era o lugar para começar a mudar o mundo e toda a idealização sobre o que era ser aluno e o que era ser professor. O choque de realidade foi imediato. Sim, eu tinha muitas idealizações, apesar das diversas disciplinas que cursei na licenciatura e que me apontavam para a complexidade da educação.

Entre 2003 e 2005 atuei como professora contratada da rede estadual de ensino de São Paulo, na maior parte do tempo como eventual, ou seja, sem classe atribuída, lecionando as disciplinas de História e Geografia. Me efetivei em 2005 na rede municipal de ensino de São Paulo, onde permaneço como docente até hoje. Entre 2003 e 2010, passei por mais de 15 escolas e, apenas a partir de 2011, consegui completar a minha jornada em uma única unidade. Durante esse período, muitos eventos os quais vivenciei, relacionados ao tema da indisciplina e da violência na escola me marcaram, destacarei nesse artigo dois que considero os mais significativos.

\subsection{Caso 1: A chegada na rede municipal de ensino de São Paulo}

A expectativa de me efetivar como professora de escola pública me acompanhou a partir do final da graduação em Ciências Sociais, no ano de 2002. Desde então, grande parte da minha experiência como docente concentrava-se no ensino médio. Em 2005, quando me efetivei na rede municipal, passei a lecionar exclusivamente no ensino fundamental. Afora as diferenças marcantes entre as redes, havia também o desafio de lecionar para alunos mais novos, com idade entre 11 e 14 anos.

Minha primeira aula na rede municipal destinava-se ao atendimento de uma turma de $7^{\mathrm{a}}$ série/ano. Ao chegar na escola, fui orientada pela auxiliar de período cargo que existiu por pouco tempo na rede, em que um professor assumia a função de organização do período - a me dirigir até a sala, sem nenhuma apresentação prévia, e “dar" a minha aula. A escola estava localizada em uma área de vulnerabilidade social da cidade de São Paulo, ocupava um prédio antigo, no formato de uma caixa, com pouca luminosidade e ventilação, nenhuma área verde e muitas escadas. A sala de aula em questão ficava no piso superior. $\mathrm{O}$ cheiro de comida que saia da cozinha às três da tarde infestava todo o prédio. 
Ao chegar até a porta me deparei com uma cena até então surpreendente para mim. Muitos alunos estavam em pé em cima das mesas, movimentando os braços para cima e para baixo, emitindo sons de passarinhos, como se assim o fossem. Parada na porta, observei atentamente a cena por alguns instantes, tentando entender o que acontecia. Os alunos continuaram performando por alguns minutos, até que a auxiliar de período chegou no local acompanhada da direção da escola. Sem dirigir nenhuma palavra a mim, as profissionais adentraram a sala e a auxiliar de período proferiu a seguinte frase: "Pessoal, o que está acontecendo aqui? A sala está cheia de passarinhos? Pessoal, vamos parar, por favor! De onde a professora vem não tem essas coisas, ela não está acostumada com isso. O que a professora irá pensar de vocês? Vamos mostrar pra ela que apesar de pobres, vocês são educados!"

Essa frase me marcou profundamente, não emiti nenhum comentário a respeito. Entrei na sala, me apresentei aos alunos e iniciei a aula com a sensação de que havíamos começado mal, afinal, a auxiliar de período já havia me colocado em uma posição de superioridade cultural e econômica em relação aos alunos. De acordo com o meu horário, eu deveria retornar a essa turma na terceira aula e imaginei que dessa vez seria melhor. Ao retornar à sala de aula, a cena se repetiu e a auxiliar de período, mais uma vez, apareceu, no entanto, seu discurso agora era outro.

Demonstrando irritação, a profissional disse que convocaria os pais dos alunos indisciplinados da turma. Uma discussão se instaurou entre ela e os alunos e a aula foi comprometida. No final do período, ao encontrar alguns alunos dessa turma no pátio fui surpreendida com ofensas e palavrões. Os alunos me xingavam de "vaca" atribuindo a mim a responsabilidade pela convocação de seus pais.

Imediatamente, procurei a funcionária e questionei a sua postura e as medidas adotadas. Expliquei que eu já tinha uma certa experiência como professora e que não gostaria de ter uma relação tutelada com os alunos. Que pretendia construir a minha relação com eles, sem a interferência dela, e que ela havia se precipitado ao convocar os pais. A auxiliar de período reagiu dizendo para eu não me preocupar que ela não havia convocado os pais, mas que era para eu me acostumar com o comportamento desses alunos.

Me disse que eu estava chegando na rede municipal de ensino e que ali era assim que funcionava, os alunos frequentavam a escola apenas para comer e como na casa deles não tinha quintal, eles utilizavam a sala de aula como um espaço de lazer. Disse 
ainda que eu conseguiria o respeito deles quando estivesse velha, gorda e feia como ela. Lecionei o ano letivo inteiro nessa escola e ao longo do tempo percebi que ali existia uma indisciplina generalizada e, muitas vezes, naturalizada entre os docentes. Vivenciei muitos episódios de indisciplina e violência, e evitei expor o problema aos colegas, com medo de que considerassem que o problema era eu.

\subsection{Caso 2: Na hora errada, no lugar errado}

Era o primeiro semestre de 2009, eu estava lecionando em um Centro Educacional Unificado (CEU) recém-inaugurado. Como ocorre com todas as unidades novas, as escolas vizinhas haviam encaminhado para o local os alunos considerados mais problemáticos, alegando que sua residência ficava mais próxima. A situação era dramática, além da falta de recursos, como livros, computadores, armários e canetões para lousa branca (novidade na época), o contato com as famílias era muito difícil, não havia dados atualizados, a equipe de profissionais da educação era nova e o sentimento de pertencimento dos alunos a essa unidade era zero.

A relação com os alunos era muito difícil, nos testavam a todo momento e não reconheciam a nossa autoridade como professores. A maioria desejava retornar para a escola de origem e também por isso nos desafiavam, esperando que fossem “devolvidos". Os problemas se acumulavam e o desgaste era grande. Tentávamos convencê-los de que a mudança era positiva, no entanto, até o momento não tínhamos muito a oferecer.

Eu lecionava em oito turmas e conhecia a maior parte dos alunos presentes nas listas, pois nem todos frequentavam a escola. Certo dia, entro em uma turma da $7^{\circ}$ série/ano, na segunda aula, e percebo a presença de um aluno novo, Rafael (nome fictício), que destoava da turma pelo seu comportamento e aparência. Era visível que a idade do aluno não era a mesma da média da turma, 13 anos. Antes de responder ao meu bom dia, Rafael se dirigiu a mim pedindo para sair da sala, sem justificativa, estava agitado e impaciente. Solicitei que o mesmo aguardasse a chamada e que depois conversaríamos.

Realizei a chamada e retomei as orientações sobre um trabalho solicitado. A atividade seria em grupo e os alunos já haviam escolhido o tema de pesquisa. Como de costume, fiz um esforço para tentar incluir o aluno novo em algum grupo, a fim de integrá-lo à turma, no entanto, sua resistência foi clara. Ofereci a oportunidade de fazer 
o trabalho sozinho e apresentei diversos temas para pesquisa. O aluno passou a questionar esse formato, dizia que seria prejudicado pois teria que realizar o trabalho sozinho, e ao mesmo tempo, discordava dos temas propostos, dificultando o alcance de uma solução. Em meio à conversa, Rafael levantou da carteira, aumentou o tom de voz e disse que não ficaria na sala. Abriu a porta e retirou-se sem autorização.

No corredor, o aluno foi flagrado pela diretora que passava, e levado até a direção. Em seguida fui chamada e questionada sobre o ocorrido. Diante do relato, a diretora entregou uma convocação a Rafael solicitando a presença do seu responsável no dia seguinte e me orientou a preencher um livro de ocorrência descrevendo o episódio. Nesse momento o tempo da aula já havia terminado e não tive mais contato com o aluno.

Ao terminar o período de aula, saí da escola em direção ao meu carro que ficava na rua, pois a unidade ainda não tinha estacionamento próprio. Na calçada fui surpreendida por um grupo de adolescentes de bicicleta, aproximadamente seis ou sete. O grupo me cercou e do meio deles saiu o Rafael gritando "É ela! Atrás dela! Pode pegar!". Nesse momento, me aproveitei do tumulto da saída e me coloquei entre uma turma de alunos da educação infantil que caminhavam em direção ao transporte escolar. Consegui chegar ao carro, no entanto, observei que o grupo de adolescentes, juntamente com o aluno em questão, também de bicicleta, me seguia. Saí com o carro e fui seguida por eles ao longo de um trecho da avenida, aproximadamente um quilômetro. Ao chegar em casa entrei em contato com a direção e relatei o ocorrido.

Retornei à escola no dia seguinte esperando conversar com os responsáveis pelo aluno, no entanto, o encontrei sentado sozinho na sala da direção. Nesse dia, meu horário começava na segunda aula. Perguntei à diretora se os responsáveis pelo aluno haviam comparecido. A mesma informou que não, mas que havia deixado o aluno entrar na escola porque ele estava sendo ameaçado de morte por traficantes do bairro e me explicou que a situação estava relacionada ao episódio do dia anterior.

Segundo a diretora, o aluno estava frequentando a escola para acompanhar de perto o trabalho de um aluno da $6^{\mathrm{a}}$ série/ano, Flávio (nome fictício), que estaria encarregado de vender drogas no local. No exato momento em que entrei na sala de aula no dia anterior, Flávio havia pulado o muro da escola e atirado um paralelepípedo no vidro de um carro estacionado na porta. Rafael havia pedido para sair da sala justamente 
nesse momento para ajudar o Flávio, que estava tendo que explicar o ocorrido para a polícia que fora chamada pela diretora.

O episódio teria chamado a atenção de dois grupos rivais de traficantes instalados no bairro, aquele ao qual Flávio e Rafael faziam parte e ainda, um segundo grupo. As facções ficaram incomodadas com a presença da polícia no local e trataram de intimidar a diretora. Na mesma tarde a diretora foi surpreendida com a visita do líder de uma das facções e, alguns dias depois, recebeu um telefonema ameaçador cujo interlocutor era um líder do grupo rival. A fala de ambos era a mesma: a polícia não deveria ser chamada pela escola em hipótese alguma. Um deles chegou a dizer que sabia onde a diretora morava, citou o seu endereço, e a aconselhou a ir embora da escola, atitude que ela tomou dias depois do ocorrido.

Se por um lado, os grupos concordaram sobre a presença da polícia atrapalhar os negócios, por outro lado, o episódio provocou um conflito entre as facções, que teve como desdobramento a chacina de alguns adolescentes, que não eram alunos da escola, na manhã seguinte. $\mathrm{Na}$ lista estava Rafael, que permaneceu na escola protegido até o final do período.

A mãe de Rafael compareceu à escola no dia seguinte. A minha conversa com ela foi acompanhada pelo grupo de professores que, em um gesto de solidariedade, fizeram questão de demonstrar que a questão não era pessoal, mas que poderia ter ocorrido com qualquer docente. Após relatar o ocorrido, manifestamos a nossa preocupação com a segurança do aluno. A senhora não demonstrou nenhuma surpresa, disse estar ciente da situação do filho, e nos informou que o pai do aluno estava preso, portanto, essa situação não era novidade para a família.

Demonstrando pressa, a mãe interrompeu a conversa várias vezes, alegando que precisava trabalhar. Aproveitando a oportunidade, me dirigi à mãe e disse que eu também era uma trabalhadora e que, como tal, necessitava de segurança para trabalhar, mas que estava me sentindo ameaçada por Rafael. Diante da minha fala, a mãe fez a seguinte indagação ao filho: "Rafael, você ia matar a professora?", e o aluno respondeu: "Eu ia mãe, mas não vou mais. Só que agora é o Murilo que quer" e a mãe continuou: "Rafael, você sabe que o Murilo mata mesmo".

Nesse momento eu percebi que não poderia contar com a mãe, que seria necessário tentar resolver a questão com o próprio aluno. Ao término da reunião, abordei Rafael no corredor e perguntei se ele pretendia realmente me matar e se 
considerava que eu havia feito algo tão grave contra ele que justificasse a minha morte. Rafael respondeu que sim, que pretendia me matar, mas não faria mais isso. Segundo o aluno, a razão seria o fato de eu ter atrapalhado o seu trabalho na escola.

Rafael disse que havia conseguido um cargo de confiança e de muita responsabilidade dentro da facção, que ele denominou "partido", que sua função era supervisionar os adolescentes que vendiam drogas na escola e no bairro, e que não gostaria de decepcionar os seus superiores. Conversamos sobre os riscos que corria fazendo parte do tráfico e ele disse estar disposto a isso. No meio da conversa insisti para que ele me garantisse que não cometeria nenhuma violência contra mim. Rafael disse que o assunto estava encerrado.

Depois desse dia nunca mais vi o aluno e, durante meses, ao dirigir da escola até a minha casa, eu tinha a sensação de que ele estava sentado no banco traseiro, por vezes, checava antes de entrar.

\section{TRANSGRESSÃO E VIOLÊNCIA: A NECESSIDADE DA AUTORIDADE ESCLARECIDA NA ESCOLA}

As situações relatadas acima estão relacionadas a diversos fatores e, portanto, não podem ser analisadas de forma isolada, pois nelas estão imbricadas, tanto as questões sociais, quanto as da própria instituição escolar. Para compreender esses fenômenos é necessário recorrer primeiro à sua diferenciação, conforme propõe Charlot (2002), pois é comum que no cotidiano escolar esses fenômenos sejam identificados e registrados por meio de expressões genéricas como "violência na escola", o que dificulta a sua compreensão.

Segundo Charlot (2002), sociólogos e pesquisadores franceses em ciências da educação propuseram a substituição da expressão "violência na escola" pelo uso de conceitos mais precisos sobre os fenômenos, tais como: 1) violência na escola, aquela produzida no interior da escola, mas relacionada a fatores sociais externos; 2) violência à escola, quando alunos praticam ações contra a instituição, como vandalismo, bater ou insultar professor; e 3) violência da escola, quando a violência é praticada pela própria instituição, de forma simbólica, por meio de palavras desdenhosas dirigidas aos alunos, organização das classes, atribuição de notas, etc. 
Além dessa conceituação, Charlot (2002) aponta ainda para a necessidade de distinguir a violência da transgressão e da incivilidade. $O$ termo transgressão refere-se ao comportamento que contraria o regimento interno da instituição, mas que não é ilegal, como faltar com respeito, não realizar os trabalhos escolares, ausentar-se das aulas, etc. Vale dizer que a transgressão é denominada por outros autores como indisciplina. Quanto à incivilidade, esta não contraria o regimento, mas sim as regras de boa convivência e se manifesta repetidamente através de empurrões, desordem, grosserias, palavras ofensivas, etc.

Quando analisados os dois casos relatados acima, percebe-se que, segundo esse referencial teórico, eles são de natureza distinta. O primeiro pode ser caracterizado como uma situação de transgressão e o segundo, como um episódio que envolve a violência na escola e a violência à escola.

A transgressão é um fenômeno que está interligado ao tipo de relação estabelecida entre professores e alunos, à própria organização da escola e, especificamente no primeiro caso relatado, à concepção de educação presente entre os docentes. Nesse sentido, é importante observar que nas situações em que a transgressão é generalizada, dificilmente o comportamento dos alunos é algo intrínseco e espontâneo, mas, geralmente, é construído e reforçado no interior da instituição. O comportamento dos alunos expressa o reconhecimento ou não de regras de convivência necessárias ao estabelecimento de condições favoráveis ao processo de ensino e aprendizagem, e à legitimidade atribuída a elas.

Assim, não basta a existência de regras impostas de fora para dentro. É necessário que os alunos internalizem a disciplina como algo imprescindível para a aprendizagem e para as suas vidas. Esse processo também não é espontâneo e, de acordo com Adorno (1995), o papel da educação é contribuir para o desenvolvimento de uma autorreflexão crítica, que leve os alunos a refletirem sobre o seu próprio comportamento e as consequências deste para si e para a sociedade. Nesse processo, é necessária a manifestação de uma autoridade esclarecida que, ao contrário da autoridade não esclarecida (autoritária), que contribui para a reprodução da barbárie, conduza o aluno a refletir sobre os seus atos e a sociedade na qual está inserido. Na escola, essa autoridade deve ser exercida pelo professor.

A autorreflexão crítica não tem como objetivo único a adaptação dos indivíduos à sociedade, embora Adorno (1995) não negue a sua necessidade, mas é fundamental 
para o desenvolvimento da crítica da sociedade tal como ela é, e, portanto, para a sua transformação. Dessa forma, o desenvolvimento da emancipação não prescinde da autoridade, mas, ao contrário, o autor aponta que, conforme pesquisa realizada por Else Frenkel-Brunswik, as crianças mais comportadas tornaram-se pessoas autônomas e com opiniões próprias antes das crianças refratárias.

Segundo Adorno (1995), para além da formação intelectual, o objetivo da escola, por mais restrito que seja o seu alcance e suas possibilidades, é desbarbarizar a sociedade. Para o autor, a barbárie se caracteriza pela agressividade primitiva, um impulso de destruição que coloca em risco a própria civilização, apesar de todo o desenvolvimento tecnológico alcançado pela humanidade. Para além da violência, a barbárie também pode se manifestar por meio da passividade inofensiva exercida por aqueles que se tornam condescendentes às suas manifestações.

Nesse sentido, com base no pensamento de Adorno (1995), é possível inferir que o comportamento transgressor dos alunos, descrito no primeiro caso, não significou uma situação atípica, uma vez que episódios como esse foram recorrentes ao longo do ano letivo, mas trata-se de uma conduta que se desenvolveu no interior da unidade e que não foi interditada por uma autoridade esclarecida que, de forma sistemática, levasse os alunos à uma reflexão crítica a respeito de seus atos.

A atitude tomada pela auxiliar de período de ameaçar convocar os pais dos alunos, assim como o seu discurso, não foram suficientes para que eles reavaliassem e modificassem a sua postura porque, segundo Adorno (1995), não basta apelar para vínculos de compromisso, é necessário a experiência, criar condições para a reflexão e o diálogo. Isso não ocorreu naquela ocasião e em tantas outras, pois os alunos já haviam sido estereotipados e a concepção de educação presente na escola, expressa pela funcionária, não permitia.

A concepção de educação presente entre grande parte dos docentes da unidade, expressa em reuniões coletivas, era de que a escola não poderia ter muitas expectativas em relação aos seus alunos, dadas as condições socioeconômicas às quais estavam submetidos, e, portanto, pouco deveriam oferecer e cobrar. Para os docentes, a principal função social da escola seria garantir a alimentação, o abrigo e a socialização, preterindo consequentemente a formação intelectual, moral, emocional e da personalidade. 
De acordo com Fanfani (2011), às expectativas negativas dos docentes quanto aos alunos de determinadas escolas estão relacionadas ao fato de que essas instituições também são estigmatizadas devido à presença de políticas educacionais compensatórias, que acabam se sobrepondo à função clássica da escola, que seria transmitir o conhecimento acumulado e socialmente relevante às novas gerações, de forma a inserilas na sociedade.

As políticas educacionais compensatórias, segundo Fanfani (2011), estão presentes em grande parte das escolas latino-americanas, desde a década de 1990, com o objetivo de garantir as condições mínimas necessárias à aprendizagem, como alimentação, uniforme, material didático, transporte, etc. No entanto, tais políticas, ao mesmo tempo que são fundamentais para a garantia do acesso e permanência das crianças à escola, também acabam gerando efeitos perversos de hierarquização e estigmatização por parte de todos os atores escolares, docentes, alunos e até as famílias. Para o autor, "Muchos tienden a crer que los chicos de las clases más subordinadas y excluidas no están em condiciones de aprender lo mismo que los 'chicos normales', o que van a la escuela sólo para comer" (FANFANI, 2011, p. 145).

Esse preconceito, conforme aponta Fanfani (2011), pode favorecer o desenvolvimento de atitudes de condescendência pedagógica que se expressam por meio da adoção de programas de ensino (currículo) e avaliações menos ambiciosas, e até mesmo na promoção automática. Quando analisado o caso relatado, é possível observar que a atitude de condescendência pedagógica se manifesta também na indisposição dos profissionais da educação em promover de forma sistemática, reflexões e diálogos junto aos alunos acerca das implicações de tais comportamentos na sua formação.

Dessa forma, segundo o autor, à medida que os alunos são excluídos do conhecimento, instaura-se o círculo vicioso da desigualdade, ou seja, a escola acaba reproduzindo a injustiça social que nela se repercute. Portanto, "la privación cultural es siempre dominación cultural, lo cual em el limite excluye la consciencia de lá própria situácion (...). La exclusión del conocimiento casi siempre se associa com uma incapacidade de demandar aquello de lo que se está excluído" (FANFANI, 2011, p. 137). Com essa análise não se pretende, contudo, responsabilizar unicamente os professores, visto que o trabalho pedagógico depende diretamente da forma como a 
escola se organiza para atender os alunos, que em grande parte é determinada por órgãos superiores.

Assim como o primeiro caso relatado, o segundo não pode ser analisado como um fenômeno isolado. De acordo com Charlot (2002), a violência na escola não é um fenômeno novo, mas assume formas que são novas, que embora mais raros, como estupros, homicídios, ou agressões como armas, produzem uma angústia social devido à percepção de que a escola não é mais um lugar protegido. Além disso, observa-se que os jovens envolvidos em situações de violência na escola são cada vez mais novos. Esses jovens, geralmente, são ao mesmo tempo autores e vítimas da violência, uma vez que padecem de diversas formas de violência social, como problemas familiares, desemprego, uso de drogas, agressões sexuais, etc.

A situação de violência envolvendo os alunos Rafael e Flávio, expressa a vulnerabilidade da instituição escolar e de seus profissionais frente a esse fenômeno, assim como a fragilidade desses adolescentes que desde muito cedo, devido a uma série de fatores sociais, passam a estar submetidos ao comando do tráfico. O trabalho nessas facções torna-se um meio de sobrevivência para esses garotos, ao mesmo tempo que os expõe ao risco de morte a qualquer momento. Flávio, por exemplo, foi morto alguns anos após o evento ocorrido na escola, não se sabe ao certo se pelo tráfico ou pela polícia.

Conforme a conceituação apresentada por Charlot (2002), o episódio envolveu dois tipos de violência: na escola e à escola. Nesse caso, os fenômenos estavam imbricados. A reação de Rafael contra mim foi decorrente, segundo ele próprio, da necessidade de proteger Flávio, um trabalhador do tráfico. Nesse sentido, a violência que se manifestou na escola foi consequência da violência presente na sociedade, embora o momento pelo qual a instituição também apresentava condições favoráveis a tais incidentes. Sobre a questão da instituição, o autor aponta que quando se analisam os estabelecimentos de ensino onde a violência escolar é grande, encontra-se uma situação de forte tensão entre professores e alunos, que pode estar relacionada a fatores externos, como o estado da sociedade e do bairro, e a própria escola.

Acerca da violência na sociedade contemporânea, Ianni (2002) afirma que esta é fabricada pela própria trama das relações sociais e pelos jogos das forças políticoeconômicas. A violência, portanto, parece algo intrínseco à forma pela qual a sociedade moderna se organizou e se desenvolve, é inerente ao capitalismo, e está presente desde a 
exploração da natureza e do trabalhador, nas relações de poder e nas instituições, além de adquirir refinamentos sofisticados, traduzindo-se em técnicas de controle social.

A violência em suas diversas formas, material, física, espiritual, ideológica, se manifesta também no interior da escola. Essa violência é o que Adorno (1995) denominou barbárie, cujo combate é a principal função da escola. Tomando como referência o pensamento de Freud, o autor afirma que a barbárie está em cada um de nós, podendo ser cultivada ou não. Para que ela seja contida é necessário, portanto, a superação da heteronomia, ou seja, é necessário que o indivíduo desenvolva, desde a primeira infância, a capacidade de refletir criticamente acerca de seus atos e sobre a sociedade que vive, se tornando menos vulnerável ao que lhe é imposto a partir do exterior, evitando, portanto, reproduzir a barbárie presente em cada um e na sociedade. Nesse processo, a figura do professor como uma autoridade esclarecida é fundamental.

\section{CONSIDERAÇÕES FINAIS}

Dentre as diversas questões às quais o professor se depara ao iniciar a sua atividade profissional, a relação entre professor e aluno é sem dúvida fundamental, uma vez que a partir dela será estruturado todo o trabalho pedagógico. Essa relação é determinada tanto por questões subjetivas, como a concepção de educação, quanto objetivas, aquelas que dizem respeito à questão própria da organização escolar e do contexto social em que a instituição está inserida.

A relação entre professores e alunos é permeada e influenciada, portanto, por diversas situações presentes no cotidiano escolar como os conflitos - que fazem parte do processo de socialização e aprendizagem - a transgressão, e incivilidade, os diversos tipos de violência, etc. Sendo assim, é necessário que os docentes se dediquem a compreender a natureza particular de cada um desses fenômenos, por meio de diversos referenciais teóricos, de forma a identificar a sua origem e complexidade e, a partir daí, propor ações coletivas para o seu enfrentamento na escola.

Esse exercício, que precisa ser sistemático, é necessário não porque será possível eliminá-los por completo do cotidiano escolar, mas para que a partir da sua manifestação, seja possível problematizá-los junto aos alunos. Para que isso ocorra é necessária uma compreensão ampla dos fenômenos, para além dos muros da escola. 


\section{REFERÊNCIAS}

ADORNO, T. W. Educação e emancipação. São Paulo: Paz e Terra, 1995.

CHARLOT, B. A violência na escola: como os sociólogos franceses abordam essa questão. Sociologias [online], Porto Alegre, 2002, n.8, p. 432-443.

FANFANI, E. T. La escuela y la cuestión social. Buenos Aires: Siglo Veintiuno Editores, 2011.

IANNI, O. A violência na sociedade contemporânea. Estudos de Sociologia [online]. Campinas, 2002, v. 7, n. 12, p. 7-30. 


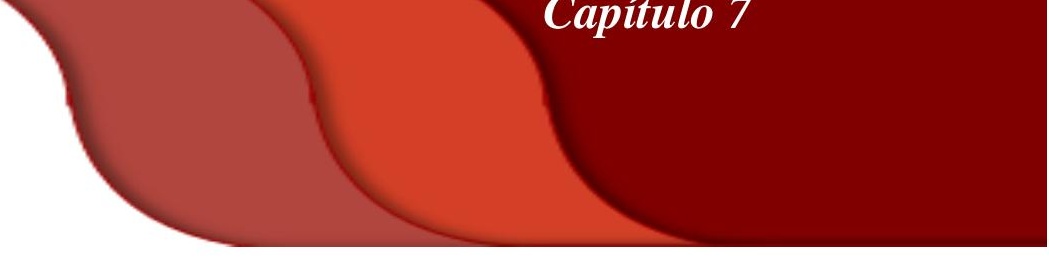

LIMITES E POSSIBILIDADES NO PROCESSO DE ENSINO E APRENDIZAGEM DA LÍNGUA INGLESA NA EDUCAÇÃO BÁSICA: UMA REFLEXÃO METODOLÓGICA LIMITS AND POSSIBILITIES IN THE PROCESS OF TEACHING AND LEARNING THE ENGLISH LANGUAGE IN BASIC EDUCATION: A METHODOLOGICAL REFLECTION

Hugo Leonardo de Almeida ${ }^{7}$

\section{RESUMO}

Este artigo aborda o ensino e aprendizagem da Língua Inglesa (doravante LI), seus desafios e possibilidades. Tem como objetivo principal apresentar reflexões sobre as potencialidades e dificuldades encontradas no trabalho com a língua inglesa na educação básica, além de discutir novas possibilidades de ensino de LI afora de uma proposição meramente conteudista, e refletir a necessidade da inserção dos estudantes de LI como sujeitos usuários dessa língua franca num âmbito global, intercultural e multifacetado. A problematização desta pesquisa está entorno das dificuldades que professores e alunos encontram no processo de ensino e aprendizagem da LI nas escolas públicas e questiona se há possibilidades que ambos podem encontrar, mesmo em meio às adversidades, para que este processo se torne de fato efetivo. A metodologia utilizada na pesquisa é de análise bibliográfica e documental. Os resultados demonstram que, apesar das dificuldades que possam encontrar, é possível ensinar e aprender inglês dentro de um contexto onde professor e aluno sejam sujeitos ativos que podem e devem se inteirar da cultura do outro, mas que também podem se sentir como agentes de criação dessas culturas como cidadãos de uma aldeia global cheia de diversidade, e não meramente como expectadores passivos de um conhecimento que denotaria pouca influência em sua vida prática cotidiana. Isso implica dizer que o reconhecimento do lugar de fala do outro é tácito assim como o reconhecimento de si mesmo, usuário da LI, como partícipe de um mundo em que a cultura alheia também pode ser nossa cultura.

Palavras-chave: Língua inglesa. Ensino e aprendizagem. Língua inglesa como língua franca. Interculturalidade.

\footnotetext{
7 Pedagogo, Licenciado em Letras, Especialista em Letramento e Alfabetização, Psicopedagogia, Especialista em Gestão da Educação Pública pela Universidade Federal de São Paulo-UNIFESP (2019) e Bacharel em Teologia. Exerceu a função de Diretor de Unidade Escolar da Prefeitura Municipal de Santo André no período de 2013 à 2016. Atualmente é Professor de Educação Infantil e Ensino Fundamental I das prefeituras de Santo André e São Paulo.
} 


\section{INTRODUÇÃO}

O ensino e aprendizagem da LI tem se tornado cada vez mais desafiador para professores, alunos e comunidade escolar. Sabemos que existem muitos entraves políticos e estruturais que impossibilita um trabalho que permita aos alunos uma aprendizagem dessa língua estrangeira de uma maneira mais efetiva.

Precisamos pensar em como transpor o pensamento equivocado que aprender inglês em escola pública não é possível, pois é um tipo de conhecimento inacessível, distante da realidade deles e que faz pouquíssimo sentido seu uso na sociedade (PONTES; DAVEL, 2016).

A partir disso podemos levantar certos questionamentos que nos permitem refletir sobre quais possibilidades nos ajudam a superar tais dificuldades e sobre como o professor pode ir além de aulas que findam o conteúdo em si mesmo, tais como: As dificuldades devem limitar a nossa prática pedagógica? Quais são as possibilidades que temos para que o ensino e aprendizagem de LI sejam de fato efetivas? As barreiras que encontramos dificultam o ensino e aprendizagem de LI? Dizer que é impossível ensinar e aprender LI em escola pública é um mito?

A pesquisa realizada é de natureza qualitativa, uma vez que buscamos compreender o contexto do ensino e aprendizagem de LI em escolas públicas de Educação Básica. Buscamos em diversos autores que abordam este assunto referenciais para que pudessem contribuir com a reflexão.

Este trabalho está composto de uma Introdução, do tópico 2 Reflexões Sobre o Processo de Ensino e Aprendizagem da Língua Inglesa no Ensino Fundamental e no Ensino Médio: Desafios e Possibilidades, onde discutiremos a problemática levantada e como os referenciais teóricos nos ajudam a refleti-lo, a Conclusão onde conseguimos propor algumas respostas aos questionamentos levantados nesta pesquisa, e as Referências que apontam as produções científicas que nos deram a base para discorrermos sobre o assunto. 


\section{REFLEXÕES SOBRE O PROCESSO DE ENSINO E APRENDIZAGEM DA LÍNGUA INGLESA NO ENSINO FUNDAMENTAL E NO ENSINO MÉDIO: DESAFIOS E POSSIBILIDADES}

O ensino e aprendizagem da LI têm sido um grande desafio para a educação básica. Em muitos casos essa disciplina não é vista e tratada com seu merecido valor. Sabemos de sua extrema importância na formação de todo sujeito para o exercício pleno de sua cidadania em um mundo cada vez globalizado e unificado mediado por esta língua franca, seja nas relações comerciais, seja para fins turísticos ou mesmo científico (PONTES; DAVEL, 2016).

Nas escolas privadas essa perspectiva demonstra ser diferente. Para Pontes e Davel (2016) o ensino de língua inglesa é um grande diferencial e tem um merecido destaque na publicidade das escolas (principalmente as bilíngues). Na escola pública esse viés já não é utilizado, pois não há necessidade de promover a competitividade com a oferta de serviços diferenciados, pois este lócus não oferece a educação como um produto de mercado e é aí que nossa discussão se inicia.

Infelizmente nas escolas públicas podemos perceber que há uma série de dificuldades estruturais para o exercício docente, tais como pouca variedade de materiais didáticos e outros recursos que auxiliam no desenvolvimento das aulas, a falta de conhecimentos da língua inglesa por parte dos professores e também o baixo interesse dos estudantes em participar das aulas. Essa junção de fatores contribui para que o ensino de LI seja prejudicado e não atinja os objetivos propostos inicialmente. Ferreira e Araújo concordam com essa problematização aqui explicitada ao dizerem que

É relevante salientar que as dificuldades estão relacionadas com a falta de motivação em aprender, como também o despreparo do professor para ensinar o idioma. Outro fator que faz com que o aluno se sinta desmotivado é o material didático que é utilizado em sala, pois não condiz, na maioria das vezes, com sua realidade e o professor por não ter domínio do assunto não busca outras fontes que possam auxiliá-lo (FERREIRA; ARAÚJO, 2018, p. 156).

Esta observação é muito necessária porque o professor de LI precisa estar atento a estes desafios, buscando superá-los para propor suas aulas com um dinamismo diferente. Estas dificuldades ora expostas não podem conduzir corpo docente e discente ao fracasso costumeiro, antes precisam buscar uma forma de transpor as limitações e 
propor um trabalho, estudo e pesquisa dentro das possibilidades que encontrarem no momento. Não cabe ao professor somente procurar os culpados pelos erros do sistema e continuar cultivando a crença que, em virtude dessas problemáticas, não é possível ensinar e aprender inglês na escola pública, antes caberá ao docente, além de suas escolhas didáticas mais apropriadas para as diversas turmas do Ensino Fundamental e Médio, fazer "uma reflexão sobre sua prática e métodos utilizados" (PONTES; DAVEL, 2016, p. 104). Refletir sobre seus métodos de ensino, sua prática e sobre como e por que os alunos aprendem é fundamental para que este professor possa aferir qualidade no seu trabalho e que consiga efetivar uma aprendizagem da LI mesmo diante de tantas adversidades.

O professor precisa se preocupar, além da estrutura, em como provocar no estudante o interesse pela aprendizagem e o reconhecimento da necessidade de aprender a língua franca que permitirá a cada um deles ampliar seus horizontes neste mundo onde as fronteiras estão sendo cada vez mais superadas, transpondo as barreiras linguísticas.

A realidade onde a escola está imersa, o contexto social dos estudantes e assuntos da atualidade das crianças e adolescentes precisam ser levados em consideração desde o planejamento da aula deste professor até sua implementação na prática em suas aulas. A aprendizagem da LI precisa ser interessante, exigir certa investigação, fazer sentido e estar associada às próprias vivências dos estudantes. A relação professor e aluno deve ser colaborativa. Ambos precisam criar um clima amistoso entre si de forma que o objeto de conhecimento seja apreciado por todos.

A cumplicidade do professor com os alunos envolve compartilhar com eles um objetivo, que não é nem o objetivo do professor e nem o do aluno; é o objetivo da turma. É esse objetivo comum que vai resolver os conflitos e fazer com que as diferenças individuais funcionem em distribuição complementar, vencendo uma a uma as dificuldades que aparecem pelo caminho. [...] Unida a turma em torno de um objetivo comum, resta o último passo: angariar os meios disponíveis numa determinada comunidade para alcançar o objetivo. No caso da língua estrangeira, os meios são os artefatos culturais (livros, recursos de áudio, vídeos etc.) e as pessoas (professor, colegas, amigos etc.) que se podem acionar para aprender a língua (LEFFA, 2011 apud FERREIRA; ARAÚJO, 2018, p. 159).

Infelizmente existe uma mentalidade na sociedade de que aprender inglês em escola pública não é possível e isso não é verdade (pelo menos não deveria ser). Professores de LI repetem os mesmos conteúdos todos os anos, empobrecendo dessa 
forma a aprendizagem. É preciso superar esse tipo de prática e professores e alunos devem potencializar suas capacidades intelectuais na elaboração de um projeto pedagógico que proporcione uma aprendizagem muito mais efetiva da que temos hoje (CHAGAS, 2016).

Sabemos que cada aluno tem seu tempo e ritmo de aprendizagem, embora isso seja verdade, não podemos assumir uma postura diante deles com o pensamento de que não são capazes de falar, escrever, ler e ouvir em língua inglesa. Para que essa aprendizagem aconteça é preciso motivar os estudantes a vivenciar situações em que a língua inglesa esteja dentro de um contexto significativo e real, pois aprender uma língua está além de decorar palavras, traduções ou regras gramaticais, é antes a imersão em um lugar de fala distinto do seu. Despertar esse pensamento no aluno é o grande desafio do professor de LI.

Uma prática que permite o aluno a conhecer a cultura do outro (porque estudar língua é estudar cultura) seria o êxito de uma proposta de ensino porque mais do que simplesmente aprender a falar e entender em inglês em determinados contextos (como falar em restaurante, como falar em uma entrevista de emprego, como falar em aeroportos, entre outras circunstâncias), é preciso compreender que marcas as outras comunidades ao redor do mundo deixam na sociedade a partir da linguagem e do discurso. Ferreira e Araújo (2018) corroboram com essa reflexão afirmando que

O sujeito que procura aprender uma língua nova é um indivíduo, peculiarmente, interpelado por diferentes discursos de ordens distintas. Todo principiante de uma língua estrangeira procura um lugar em um universo discursivo da língua do outro. Neste caso, refere-se a querer estar, viver, se sentir e ser sujeito que sabe levar a vida em sociedade, um sujeito que dialoga e deixa marcas discursivas neste viver (FERREIRA; ARAÚJO, 2018, p. 155).

Com isso podemos inferir que a língua inglesa é multifacetada. É uma língua que não está limitada em situações contextuais fixas e imutáveis. E podemos ir além, também é possível inferir que o idioma não é mais determinado somente por falantes das ilhas britânicas e/ ou dos Estados Unidos da América nem tampouco pelos países quem foram colonizados pela Inglaterra, e por esta razão possui uma variedade linguística imensa, de dimensões globais.

Como língua franca que é, o mundo inteiro utiliza a LI para se comunicar independente da finalidade. Além dos nativos de países de LI, pessoas de inúmeras 
culturas podem ser consideradas falantes dessa língua e esta realidade precisa ser levada ao conhecimento dos estudantes como forma de despertamento para a construção de sua identidade dentro de uma aldeia global. Desta forma, os alunos podem começar a sentir não somente uma necessidade de aprender este idioma como também podem se sentir como sujeitos que dialogam e também deixam marcas nesta prática discursiva da Língua Inglesa.

Nessa direção [...] os motivos para se aprender inglês precisam enfatizar a ideia de que a comunicação com outros falantes nãonativos de inglês ao redor do mundo é relevante. Além disso, outras variedades da língua inglesa que não apenas norte-americana ou britânica precisam ser apresentadas aos alunos no desenvolvimento das habilidades receptivas e nas de compreensão, assim como os temas trazidos para a sala de aula, os quais abrangem questões sociais de alcance global, precisam ser ampliados. Além disso, faz-se necessária uma maior conscientização sobre o papel das línguas nas sociedades e, especialmente, do inglês como língua de comunicação internacional, bem como sobre sua expansão no mundo e sua vinculação com a [atual] globalização econômica. [...] ensinar e aprender inglês como língua franca implica colorir as salas de aula com diversos sotaques oriundos de lugares distantes e esquecidos, trazendo as vozes dos guetos, das minorias, dos imigrantes com suas tradições culturais de diferentes continentes, como a África, Ásia e América, e até do interior das grandes metrópoles dos países hegemônicos de língua inglesa (SILVA, 2019, p. 161).

A partir desta reflexão, podemos considerar que ensinar e aprender LI são, antes de tudo, permitir se posicionar em um lugar onde é possível compreender a heterogeneidade cultural e perceber como nos incluímos nela. Compreender que a língua é deles, da cultura do outro, mas também, como usuários dessa língua, também é nossa e que, por meio da linguagem, também somos sujeitos e agentes da construção dessa intercultura multifacetada. Essa reflexão nas aulas de LI torna muito mais possível uma aproximação real dos estudantes desta disciplina por permitirem se sentir pertencentes ao mundo globalizado.

\section{CONSIDERAÇÕES FINAIS}

Percebemos através dessa pesquisa que o ensino de LI precisa transpor muitas barreiras para que alcance um destaque merecido no âmbito da Educação Básica. Sabemos que as políticas públicas têm favorecido pouco o engajamento das diversas 
redes de ensino na oferta de um ensino dessa língua com maior sucesso. A formação do professor ainda precisa melhorar muito, pois eles vão às escolas pouco instrumentalizados para a prática docente e com conhecimentos muito baixos sobre o funcionamento da língua.

O ensino e aprendizagem de LI precisam avançar no sentido de não se aplicar somente conteúdos desconexos da realidade dos estudantes dos Ensinos Fundamental e Médio. O desinteresse dos alunos vem daí, em perceber que é preciso estudar um idioma que muita das vezes está distante de suas vivências cotidianas. A partir do momento em que professores e alunos se percebem como sujeitos que estão inseridos em um universo repleto de culturas distintas, o ensino e a aprendizagem de LI se torna real, verdadeira e possível.

Ensinar e aprender um idioma vai além do saber se comunicar. Entra num campo onde seus usuários sabem se colocar no lugar de fala do outro, sabe respeitar a cultura alheia, reconhece que existe uma comunidade mundial repleta de diversidades e que o acesso a elas se dá a partir do uso efetivo da linguagem e do respeito mútuo. Este processo não se limita a aprender regras gramaticais desconectadas de uma situação real, mas possibilita a inserção de novos sujeitos em um mundo globalizado onde todos os sujeitos são considerados como pertencentes a ela e que além de ser a língua do outro é também língua nossa porque nos possibilita se apropriar de outros espaços e culturas além de formar a nossa própria identidade como cidadão do mundo.

\section{REFERÊNCIAS}

CHAGAS, A. F. das et al. Dificuldades de aprendizagem da Língua Inglesa no Ensino Fundamental: um estudo de campo. Form@re. Revista do Plano Nacional de Formação de Professores da Educação Básica, Universidade Federal do Piauí, Teresina, v. 4, n. 1, p.138-141, jan. / jun. 2016.

FERREIRA, E. da S.; ARAÚJO, J. M. de. Perspectivas e desafios no ensino de língua estrangeira na escola pública. Revista Diálogos, Brasília, n. 20, p. 149-169, set./ out. 2018.

PONTES, V. de F.; DAVEL, M. A. N. O inglês na educação básica: um desafio para o professor. REVISTA X, v. 1, p. 102-117, jan. 2016.

SILVA, F. M. da. O ensino de língua inglesa sob uma perspectiva intercultural: caminhos e desafios. Trabalhos Em Linguística Aplicada, Campinas, v. 58, n. 1, p. 158-176, jan./ abr. 2019. 


\title{
ENSINO REMOTO E PANDEMIA: BREVES CONSIDERAÇÕES REMOTE EDUCATION AND PANDEMICS: BRIEF CONSIDERATIONS
}

\author{
Sandra Maria Sanches ${ }^{8}$
}

\section{RESUMO}

O presente texto apresenta um estudo exploratório e inicial acerca do impacto, curricular e organizacional, da pandemia do novo coronavírus com o isolamento social e proposta de atividades escolares no modo remoto em escola de ensino fundamental da rede municipal de São Paulo. O objetivo central foi verificar a predominância da tecnologia digital nas relações escolares ou se permanece como promessa pedagógica pendente, como nos assevera Charlot (2020). Considerando as respostas ao questionário aplicado, foi possível constatar a ineficiência do atendimento remoto por falta de condições objetivas, como inexistência ou precariedade dos objetos tecnológicos e rede de sinal disponíveis para as famílias e profissionais da escola, bem como a falta de domínio dessa linguagem na qualificação do processo educativo.

Palavras- chave: Ensino remoto. Pandemia. Trabalho pedagógico.

\section{INTRODUÇÃO}

O presente texto relata uma experiência minha, vivida numa escola pública de ensino fundamental e se caracteriza por um estudo exploratório e inicial acerca do impacto, curricular e organizacional, da pandemia com o isolamento social e proposta de atividades escolares no modo remoto.

A pandemia do novo coronavírus causou impacto substancial na vida de todas as pessoas não só no Brasil, mas em todo o mundo. Evidentemente, que esse impacto foi mais intenso na vida das pessoas das sociedades com maiores discrepâncias socioeconômicas.

No Brasil, escancarou além das mazelas de nossa sociedade, um projeto nacional de extermínio de parte da população (indígenas, homossexuais, mulheres, religiosos de matriz africana...). Lidera o ranking e se mantém, até o presente momento, como o país com maior número de mortes, como pode ser constatado nos noticiários nacional e internacional.

\footnotetext{
${ }^{8}$ Doutora em Educação pela PUC-SP, no PEPG: História, Política, Sociedade. Área de Estudos: Gestão Escolar. Diretora de Escola na rede municipal de ensino de São Paulo.
} 
A pandemia impôs a todos e a todas novas formas de relações em todas as esferas da vida. O espaço virtual se configurou, de um dia para o outro, como o principal (ou único) espaço possível de contatos interpessoais, de trabalho, de saúde, de estudos, de compras.

Em relação à educação, pôs em xeque alguns discursos legitimados, como a predominância da tecnologia nas relações escolares; a desqualificação ao trabalho docente; a educação domiciliar como solução na preservação de valores familiares.

Na escola, a única possibilidade para o desenvolvimento das atividades escolares, bem como o contato, foi mantido por meio deste espaço virtual. As atividades e informações passaram a ocorrer por meio de plataformas digitais acessadas por celulares, tablets e computadores e/ ou whatsapp.

Segundo Sampaio (2002), a escola realiza (ou realizava) o trabalho escolar respaldando-se na tradição, mantendo certo equilíbrio em sua atuação, protegendo sua cultura e sua tradição erigidas nas precariedades para o atendimento de números cada vez maiores de estudantes com realidade extremamente diversificada e muitas vezes desconhecida da instituição escolar.

A autora afirma que, nas últimas décadas, a escola paulista manteve parâmetros organizadores de prática baseados em pré-requisitos ou programas das séries para nortear o trabalho docente "[...] fixando o modelo de transmissão coletiva, memorização e mecanização [...]" (SAMPAIO, 2002, p. 10). Este modelo curricular de ensino já apresentava defasagem no aprendizado, tendo em vista que não garantia o acesso ao conhecimento.

O formato de atendimento remoto, a meu ver, desacomodou o funcionamento desta escola que esteve calcado desde sempre no contato pessoal e presencial. Portanto, é possível indicar que a escola e seus profissionais foram atingidos na base constitutiva de atuação e organizacional, evidenciando a precariedade material e formativa.

Nessa nova forma de atendimento, o uso dos objetos tecnológicos invadiu e representou a única ferramenta para mediação das relações escolares. A escola precisou aderir ao ciberespaço com as limitações tecnológicas que possui.

Lévy (1999) em sua obra intitulada Cibercultura, se propôs a pensar a cibercultura numa perspectiva otimista de reconhecimento que o crescimento, rápido e sem fronteiras, do ciberespaço resulta do movimento de jovens que desejam experimentar, coletivamente, diferentes formas de comunicação e que existe a 
possibilidade de exploração das potencialidades positivas deste espaço nos âmbitos da economia, da política, da cultura e da humanidade.

Em obra mais recente Charlot (2020) problematiza e apresenta conclusões menos otimistas em relação ao uso das tecnologias digitais. Para ele, elas permanecem como promessa pedagógica pendente. Não nega o fato de que essa invasão tecnológica se tornou fundamental e irreversível. No entanto, assevera que a principal atividade dos jovens não é aprender, mas acessar informações, sem aprofundamento, daquilo que lhes interessa e para facilitar a realização de algumas tarefas escolares.

Para Lévy (1999) a cibercultura representa a mutação da comunicação e expressa:

[...] o surgimento de um novo universal, diferente das formas culturais que vieram antes dele no sentido de que ele se constrói sobre a indeterminação de um sentido global qualquer (LÉVY, 1999, p. 15).

Para análise dos impactos tecnológicos na cultura, o autor sugere retomar a ideia da técnica como produto de interação e constituição humana, considerando, portanto, a interdependência nas relações entre técnica, cultura e sociedade. Técnicas estas que criam condições novas e possibilitam ocasiões para o desenvolvimento individual e social.

Em perspectiva crítica, Charlot (2020) destaca que a utilização das tecnologias, ao permitirem maior rapidez nas formas de comunicação, induz formas abreviadas de expressão que vai à contramão da lógica escolar que, por sua vez, considera formas, ritmos e processos menos imediato, mais lentos e progressivos.

Acessar um vasto conjunto de informações é muito diferente de acessar conhecimento ou saber. O saber é mais do que o conjunto de informações acerca de determinado assunto; envolve capacidade de articular, ordenar e sistematizar estas informações para "responder a uma questão, resolver um problema, entrar em um universo de significado e sentido" (CHARLOT, 2020, p. 109).

Tal cenário, segundo esse autor, impõe grande desafio pedagógico em relação à atuação docente. A conversão do professor de informação para um professor de saber, tendo em vista que o Google é capaz de responder a qualquer pergunta em questão de segundos, porém essas respostas nem sempre são convertidas em conhecimento. 
Buscar evidências que caracterizem impressões ou vivências do movimento do ensino remoto imposto pela pandemia, com base na visão das famílias, dos estudantes e dos profissionais da educação é o objetivo dessa breve pesquisa para futuras intervenções pedagógicas.

\section{PROCEDIMENTOS E BREVE ANÁLISE}

Tomei a iniciativa de aplicar um questionário, digital, junto aos segmentos representativos da escola: professores, estudantes, famílias, funcionários. Interessavame saber se, de fato, esse mundo digital era de domínio, sobretudo dos estudantes que, como costumamos dizer, nasceram na era digital.

Como nos assevera Bourdieu (2011), a construção do dado deve ser embasada no entendimento da lógica social na qual o mesmo foi construído, ou seja, nas palavras dos entrevistados, deve-se saber ler a estrutura das relações objetivas, presentes e passadas, entre sua trajetória e a estrutura e a história do espaço das relações que se expressam nas relações que se investiga. Deve ser observada a relação dialética entre a estrutura e o indivíduo.

Nesse sentido, não se pode desconsiderar o fato de que todos nós estamos sob a pressão de uma pandemia de um vírus altamente contagioso e desconhecido; bem como o fato de que o isolamento social afetou a economia em nível mundial, trazendo como consequência altamente danosa para as famílias, a perda da renda para sobrevivência.

A presente investigação foi realizada em uma escola de ensino fundamental, localizada no bairro de Perus, um território com pouca opção para lazer, e os estudantes da escola, em sua maioria, são provenientes de famílias com reduzido capital cultural, social e econômico que investem muito ou todo seu tempo na luta pela sobrevivência.

Tais informações são importantes para entendermos os motivos que levaram às escolhas (ou não) dos objetos tecnológicos a serem utilizados bem como a manutenção de vínculos com alguns fazeres essencialmente presentes nas relações escolares, como o conhecimento científico, leitura e escrita sistematizada.

Além disso, são extremamente importantes no desenvolvimento das estratégias e metodologias a serem refletidas no desenvolvimento de planos de ação para o retorno destes estudantes e reorganização dos espaços e atividades escolares. 
As informações foram coletadas de um questionário curto, organizado com perguntas fechadas e abertas, com linguagem adequada ao entendimento de todos, com perguntas objetivas e curtas. As respostas abertas eram facultativas aos respondentes. Foi divulgado por meio das redes sociais utilizadas para comunicação com famílias e estudantes (facebook e whatsapp) e plataforma TEAMS.

O quadro completo da escola compreende aproximadamente 600 estudantes e 50 professores. Levando em conta esse universo, pode-se concluir que a adesão foi baixa, tendo em vista que a pesquisa retornou 74 respostas - pouco mais de $10 \%$ em relação ao quantitativo de estudantes e professores. Dos estudantes respondentes (aproximadamente metade das respostas), a prevalência esteve entre os matriculados no Fundamental II ( $6^{\circ}$ ao $9^{\circ}$ ano $)$.

A primeira questão solicitava que definissem a escola, por meio de três palavras, com aulas remotas.

A prevalência das respostas define uma escola de forma negativa com ensino remoto. A grande maioria das palavras respondidas entre todos os segmentos foram: insegurança, desigualdade, solidão, confusão, ineficiência, dificuldade. Chamou a atenção expressões como: "se não tiver escola não tem aula" (mãe de aluno); "não entendo nada, se entendo, esqueço” (aluno).

A condição para o desvelamento dos mecanismos de reprodução das desigualdades educacionais - que são expressões de desigualdades culturais e econômicas (BOURDIEU; PASSERON, 2014) naturalizadas por meio das políticas educacionais - é a superação do que Bourdieu define como doxa: a apreensão do mundo social pelas aparências, opinião e marketing; a ausência do conhecimento do mundo social, conhecimento indiscutido.

Suas pesquisas foram levadas a cabo na tentativa de responder ao que ele chamou de paradoxo da doxa, ou seja, como a ordem do mundo segue seu rumo de maneira perpétua e sem grandes transgressões ou quais os processos responsáveis pela transformação da história em natureza e do arbitrário cultural em natural. Afirma que, surpreendentemente,

[...] a ordem estabelecida, com suas relações de dominação, seus direitos e suas imunidades, seus privilégios e suas injustiças, salvo uns poucos acidentes históricos, perpetue-se depois de tudo tão facilmente, e que condições de existências das mais intoleráveis possam 
permanentemente ser vistas como aceitáveis ou até mesmo como naturais (BOURDIEU, 2017, p. 12).

Nas respostas acima enunciadas, duas questões parecem ser desveladas. Uma, de que a aula só existe na escola, ou seja, para algumas pessoas, sobretudo das classes mais pobres, certo capital cultural só pode ser acessado na escola, fato que revela a importância da escola na vida de muitas famílias. Outra, coloca em destaque como foi ou está sendo esse aprendizado. Não é novo o dado de que há tempos, muitos estudantes passam pela escola e dela saem com conhecimentos rudimentares de leitura e escrita, sem conseguir acessar conhecimentos que lhe possibilitem decifrar o mundo e se reconhecer neste como sujeito de direitos.

Em seguida, era solicitado que justificassem a resposta e nela, foi expresso com muita evidência, inclusive nas respostas dos professores, a questão objetiva que diz respeito à plataforma institucional de difícil operação e à falta de equipamentos e objetos tecnológicos como computadores ou tablets; acesso à internet; celulares de uso compartilhado entre os membros da família.

Para ilustrar a realidade de muitas pessoas, segue a justificativa de um estudante: "É que eu só tenho o celular da minha avó pra tudo eu, minha irmã, meu irmão e ainda tem minha avó e todos nós estamos estudando e mexendo no celular e quando nós vamos estudar a gente não consegue mexer direito".

A ilustração acima expõe que a centralidade das dificuldades desse aluno está na classe social de origem, anterior à pandemia ou à operação dos equipamentos tecnológicos, pois ainda que a avó tivesse feito opção de não garantir celulares individuais, teria efetuado a compra de um equipamento que garantisse a realização das atividades escolares para os netos.

No que diz respeito ao aprendizado, as dificuldades mais relatadas abrangem a necessidade da mediação do professor; do contato com os demais estudantes; da rotina de estudo. Uma professora resume uma das dificuldades de desenvolver as atividades nesse espaço virtual: "Os alunos acabam se distraindo com outros aplicativos que tem no celular, computador ou tablet, com isso, acabam não focando totalmente nas atividades". Enquanto um estudante de $9^{\circ}$ ano exprime sua preocupação: "Muito mais confuso, esse ano e o outro [2021 e 2020], eu não aprendi absolutamente nada".

Nestas respostas é possível evocar Jackson (1992) que descreve minuciosamente a vida nas salas de aula e nos convoca a pensar sobre os objetos e as relações que 
compõem a escola para muito além do ensino ou aprendizado de conteúdos escolares. Conforme esse autor, na escola se aprende muitas coisas.

[...] viver em uma sala de aula se supõe, entre outras coisas, aprender a viver no seio de uma massa. Já fora mencionada esta verdade tão simples, porém requer uma explicação mais ampla. A maior parte das atividades realizadas na escola é feitas com outros ou, ao menos, na presença de outros e isto tem profundas consequências para a determinação da qualidade de vida de um aluno (JACKSON, 1992, p. 4).

Com base nas palavras do autor, as respostas evidenciam que o problema não está somente no uso de tecnologias digitais ou aulas virtuais, mas também no que está incorporado como sendo uma escola, uma aula, ou um estudante. As respostas exaltam a ausência e necessidade de uma das responsabilidades do professor, "canalizar as interações sociais da sala de aula" (JACKSON, 1992, p. 5).

Ao que concerne à comunicação, ainda que durante alguns meses o modelo virtual tenha sido a única possibilidade de contato, as famílias e estudantes expressam maiores dificuldades na relação com a escola e chegam a expressar sensação de abandono.

O abandono não é novidade em um lugar onde o poder público interfere pouco para garantir direitos à saúde, educação, moradia e lazer. Esse dado pode ser constatado nos dados do Censo $/ 2000^{9}$ que apresentaram, nessa região, população de 1.044 .742 habitantes com renda média mensal por habitante de $\mathrm{R} \$ 751,60$.

Conclui-se que esse abandono verbalizado, sentido de forma intensa e violenta, foi direcionado à escola porque ela representa nessa região um ponto de contato com o poder público que antes da crise sanitária mundial atravessava grande crise política, com gestão austera e antidemocrática direcionada, internamente, a setores essenciais como saúde e educação e, externamente, aos acordos e relações internacionais. Portanto, não implementou ações eficientes para garantia de renda mínima para as pessoas;

9 Média ponderada dos dados de renda e população da Prefeitura. Dados disponíveis em: <http://ww2.prefeitura.sp.gov.br//arquivos/secretarias/planejamento/plano_diretor/Plano_Municipal_Habi tacao.pdf $>$. Acesso em 20 de novembro de 2017. Cabe justificar que foram utilizados dados tratados pelo site da prefeitura que, até a presente data de acesso, disponibilizava apenas dados referentes ao Censo/2000. 
atendimento médico para a população mais carente; isolamento social para controle da disseminação do vírus.

Passando para a última questão que solicitava a escrita de duas palavras que exprimem o sentimento em relação às aulas remotas, a palavra tristeza predomina nas respostas; frustração, saudade e cansaço vêm logo em seguida.

Como é possível pensar a organização de uma escola sem considerar o medo que baliza, nesse momento, as relações escolares? No caso específico da gestão escolar, conforme Sanches (2019) o diretor enfrenta o desafio de manter o controle, tanto no sentido organizativo quanto no sentido educacional, por meio da elaboração e aplicação da política, possibilitando o desenvolvimento de solidariedade, de cooperação, de entusiasmo e de adesão, sobretudo num momento como esse no qual a escola não pode desconsiderar o luto e as desigualdades socioeconômicas e educacionais que saltam aos olhos.

Essas considerações são muito bem explicitadas por Ball (1989):

Traduzidas na linguagem mais racional e estéril da teoria da organização, essas pressões e expectativas contraditórias aproximamse das duas funções básicas da administração: a função relativa às tarefas (iniciar e dirigir) e à função humana (consideração) (BALL, 1989, p. 93).

Fica a dúvida se as políticas educacionais vão contribuir para a autonomia da gestão escolar no sentido de avaliar, encaminhar, priorizar questões com as devidas considerações dos agentes diretamente envolvidos.

\section{CONSIDERAÇÕES FINAIS}

Do exposto até aqui, restam questionamentos vários com poucas respostas ou até mesmo reflexões, quais sejam: quais respostas serão dadas pelos profissionais da escola diante do que se caracteriza como "novo normal" para as relações escolares? De onde virão algumas respostas: se vierem das propostas oficiais, como serão enfrentadas ou adaptadas na realidade escolar?

Penso ser salutar que, diante da tristeza, do cansaço e da frustração, relatada pela grande maioria, sejam garantidos espaços para expressão de sugestões, debates e reflexões, consideradas as visões de mundo destes. Pensar o processo educativo em 
situação tão adversa requer (re)pensar a função da escola; problematizar a centralidade dessa função acerca da transmissão cultural; refletir acerca do fazer pedagógico de maneira a contribuir para que os estudantes consigam aliviar o sofrimento com tantas incertezas e dificuldades desse momento por meio das possibilidades que podem ser exploradas das atividades escolares, cujo foco central é o conhecimento científico.

A pandemia caracterizou a ineficiência do atendimento remoto por falta de condições objetivas, como inexistência ou precariedade dos objetos tecnológicos e rede de sinal disponíveis para as famílias e profissionais da escola; a falta de domínio dessa linguagem na qualificação do processo educativo. Mas, também porque o processo educativo necessita, fundamentalmente, da interação social.

Resta em aberto uma questão central, no meu entendimento, as tecnologias virtuais que definitivamente invadiram os espaços e relações escolares serão convertidas em metodologias para o saber ou delimitarão a relação com o conhecimento e o desenvolvimento das capacidades humanas?

\section{REFERÊNCIAS}

BALL, S. J. La micropolítica de la escuela: hacia uma teoria de la organización escolar. Madri: Centro de Publicaciones del Ministerio de Educación y Ciencia, 1989.

BOURDIEU, P.; PASSERON, J. C. A reprodução: elementos para uma teoria do sistema de ensino. Petrópolis, RJ: Vozes, 2014, p. 21-167.

BOURDIEU, P. A dominação masculina. Rio de Janeiro: BestBolso, 2017.

Compreender. In:

A miséria do mundo. Petrópolis, Rio de Janeiro: Vozes, 2011, p. 693-732.

CHARLOT, B. Educação ou Barbárie: uma escolha para a sociedade contemporânea. São Paulo: Cortez, 2020, p. 106-125.

JACKSON, P. W. La vida en las aulas. 2. ed. Espanha: Fundación Paidea, 1992.

LÉVY, P. Cibercultura. Primeira Parte: Definições. São Paulo: 34, 1999.

SAMPAIO, M. das M. F. (org.). Apresentação. In: O cotidiano escolar face às políticas educacionais. Araraquara: JM Editora, 2002, p. 7-20.

SANCHES, S. M. Percursos: práticas dos diretores de escola da rede municipal de São Paulo. Tese de Doutorado. PEPG: História, Política, Sociedade da PUC/SP, 2019. 


\title{
IDENTIDADE E MEMÓRIA: RESSIGNIFICANDO CAMINHOS
}

\section{IDENTITY AND MEMORY: RESIGNING PATHS}

\author{
Lúcia Matias da Silva ${ }^{10}$ \\ Márcia Maria Martinelli Elias ${ }^{11}$
}

\section{RESUMO}

$\mathrm{O}$ artigo traz a narrativa da experiência profissional transformada após a trajetória da pós-graduação, momento em que os sentidos da docência ganham novos contornos. Para chegar a esse recorte, recorre-se à narração da escolha da profissão e dos primeiros passos na carreira, bem como dos desafios surgidos e que culminaram na necessidade de buscar novas perspectivas profissionais. Descrever tal experiência é um exercício de rememorar espaços de construção, desconstrução e reconstrução da identidade profissional para reavivar reflexões e explorar aprendizagens. Nesse percurso, ocorrem rupturas ao questionar um habitus que parece não mais responder aos questionamentos imputados pelo cotidiano e que requerem novas disposições que, gradativamente, agregam-se a um modus operandi renovador. A construção do conhecimento atrelada a uma prática reflexiva é capaz de mudar o discurso, o olhar, a interpretação e a leitura de mundo produzida pela teoria compreensiva do cotidiano. A reflexão da abordagem experiencial toma as histórias de vida como prática de formação e têm significado transformar o olhar sobre a própria docência e dar-lhe contornos mais expressivos, uma vez que permite confrontar diferentes singularidades presentes na prática profissional. Como a interpretação, o sentido e o discurso docente podem promover mudanças, à guisa de conclusão, a Professora Márcia Maria Martinelli Elias, nos brinda, com uma perspectiva possível, considerações sobre o olhar acerca do papel dos sentidos na interpretação de contextos como componente de transformação da realidade.

Palavras-chave: Experiência profissional. Docência. Aprendizagem. Mudança.

\section{INTRODUÇÃO}

Narrar experiências, descrever sentidos encontrados a partir do exercício de rememorar a trajetória percorrida é um espaço para reavivar reflexões e explorar os sentidos de suas vivências e aprendizagens. Os estudos, que se apropriam da abordagem experiencial e que tomam as histórias de vida como prática de formação, têm

\footnotetext{
${ }^{10}$ Mestre e Doutora em Educação. Atua profissionalmente na Escola de Aplicação da Faculdade de Educação da Universidade de São Paulo - EAFEUSP. Faculdades Integradas Potencial - FIP Cotia. Licenciatura em Geografia e Pedagogia. Especialista em Gestão Escolar.

${ }^{11}$ Doutora e Mestre em Linguística em Língua Portuguesa. Atua profissionalmente na Faculdades Integradas Potencial - FIP - Cotia. Licenciatura em Letras e Pedagogia
} 
significado transformar o olhar sobre a própria docência e dar-lhe contornos mais expressivos, uma vez que permite confrontar diferentes singularidades presentes na prática profissional.

Conforme Souza, Sousa e Catani (2007), o movimento biográfico no Brasil tem sua vinculação com as pesquisas na área educacional, seja no âmbito da História da Educação, da Didática e Formação de Professores, bem como em outras áreas que tomam as narrativas como perspectiva de pesquisa e de formação.

Revisitar trajetórias é algo que não se fixa apenas no campo subjetivo, já que toda vivência, ainda que singular, situa-se também num contexto histórico e cultural. A memória é uma experiência histórica indissociável das experiências peculiares de cada indivíduo e de cada cultura. Segundo Bosi (2003), existe um substrato social da memória articulada com a cultura, tomada em toda sua diversidade estética, política, econômica e social.

Como pensar a partir do reconhecimento da importância da subjetividade na formação docente? De que forma ela pode contribuir para uma profissionalidade docente mais lúcida e transformadora? Os estudos das histórias de vida no campo educacional centram-se na pessoa do professor, com ênfase nas subjetividades e identidades que as histórias comportam.

O narrar de si envolve a temática de ordem vivencial. Narrando de si o sujeito tem por temática sua própria vida, aquilo que marca a sua existência e a singulariza. Pensar o sujeito e sua heterogeneidade constitutiva implica, ainda, o olhar do outro, a compreensão, o acolhimento e todas as nuances de uma relação consigo mesmo, com a profissão, de modo que seja, em última instância, um espaço de partilha.

\section{BREVE BIBLIOGRAFIA}

Não somos aquilo que fizeram de nós, mas o que fazemos com o que fizemos de nós (Jean Paul Sartre)

Minha trajetória profissional carrega, desde seus primórdios, uma profunda admiração pelo ofício de ensinar, aliada à lembrança de professores significativos que ao longo de minha experiência deixaram marcas que sempre representaram estímulo decisivo para que eu persistisse na busca da excelência do trabalho docente. Os elogios, os gestos e atitudes de muitos professores funcionam como molas propulsoras capazes 
de transformar vontade em ações que, a partir das relações interpessoais nos processos de ensinar e aprender se traduziram em caminhos que ultrapassaram as barreiras das condições objetivas.

Optei pelo magistério na década de 1980 e entre todas as atribuições inerentes ao curso se inclui também a própria docência como substituta, ministrava aulas de maneira recorrente e estava em pleno processo de greve de professores do Governo Maluf que, no entanto, não eram muito discutidas nem por mim, nem pelos professores que lecionavam para o curso.

Depois de formada, atuei como professora das séries iniciais do ensino fundamental no Instituto São Pio X em Osasco, um período importante para o entendimento da estrutura organizacional de uma escola, além da própria organização do trabalho pedagógico. Nesse período, ingressei na Faculdade para o curso de Estudos Sociais e ainda, atuava no período da manhã com aulas em substituição na rede estadual de ensino.

A partir de 1986, ingressei na rede estadual como professora de Geografia, após conclusão da complementação em Geografia exigida para aqueles que haviam cursado Estudos Sociais. Em 1988, decidi fazer o curso de Pedagogia, pois, além de julgar que essa formação me ajudaria como professora, também ambicionava trabalhar na coordenação e na gestão das escolas públicas estaduais.

Concomitante à rede estadual em 1994, assumi aulas no SESI e em escolas particulares de pequeno porte, porém decidi ficar apenas na rede estadual em 1998, quando fui convidada a atuar como vice-diretora de escola, função que permaneci até 2006. Nesse período, senti uma insatisfação com relação às funções desempenhadas na escola, uma impotência diante de desafios que pareciam não ter solução, uma solidão, uma tristeza que foi, aos poucos, me tirando o prazer que sempre tive em estar na escola, foi um período em que a satisfação de ser professora parecia ameaçada.

Diante disso resolvi fazer alguma coisa, mudar de ares e me inscrevi para atuar como tutora no Projeto Pec - Formação Universitária pela Universidade de São Paulo. Felizmente fui chamada e, obviamente, que esse trabalho representava um desafio para quem estava imerso na escola pública e distante dos bancos escolares já há tanto tempo.

Na primeira edição do projeto, em 2001, trabalhei no Polo de Carapicuíba; conheci muita gente e me vi diante de um material impresso relevante para responder a muitas questões, não só dos alunos envolvidos no programa, mas também, afinal eu 
também era oriunda da escola pública.

O aprendizado da tecnologia para interação com a Universidade foi extremamente importante num momento em que as escolas começaram a receber computadores administrativos e pedagógicos. Tudo era feito por e-mail e nossa comunicação com a Universidade era feita por meio dessa ferramenta, além disso, no Polo, os alunos tinham atividades do Learnig Space e necessitavam de apoio constante, as videoconferências eram semanais, a teleconferência mensal e o envolvimento com toda essa dinâmica de trabalho me fez enxergar uma luz no fim do túnel, recuperar a autoestima, ganhar ânimo novo e a partir daí resolvi investir na minha formação.

A orientadora de TCC da minha turma era a professora Flavinês Lapo que à época era doutoranda da Profa. Dra. Belmira Bueno da Faculdade de Educação da USP e me incentivou a ir para a pós-graduação. No entanto, em função de problemas particulares tive que adiar esse projeto e ainda trabalhei no PEC na segunda edição no período noturno entre 2003 e 2004.

Em 2005, fiz um curso na USP de "Introdução aos estudos da educação" com a Profa. Dra. Maria Nazaré de Camargo Pacheco Amaral, como aluna especial da rede pública, pois buscava suporte para ingressar na pós-graduação. Em 2006, ingressei na UNICAMP para um curso de especialização em Gestão Educacional oferecido pela rede estadual de ensino do estado de São Paulo para gestores em exercício. Tínhamos aulas presenciais aos sábados e atividades em $\mathrm{EaD}$ durante a semana. Para mim, foi uma experiência muito significativa, pois, além de aprender a lidar com as ferramentas do EaD na condição de aluna, o repertório do curso agregou conhecimentos importantes à minha formação.

Nesse mesmo ano, prestei o processo seletivo para o mestrado na PUCSP e fui aprovada no programa de Estudos Pós-Graduados em Educação: História, Política, Sociedade. Em 2007, comecei o mestrado, ao mesmo tempo em que assumi a direção da escola estadual onde trabalhava desde 1986. Foi um período intenso e a participação nas aulas, aos poucos, foi me inocentando de tantas culpas pela impotência que sentia diante dos problemas vividos na escola e para os quais não encontrava solução.

Assumi uma pesquisa no Programa de Estudos Pós-graduados em Educação: História, Política, Sociedade, na linha de pesquisa Educação e Ciências Sociais sob a orientação da Profa. Dra. Luciana Maria Giovanni. Resolvi investigar a relação professor aluno e ampliar minha percepção acerca dos traços culturais presentes nessa 
relação tão conflituosa na minha realidade profissional. Tal fato se mostrava antagônico em face da minha experiência tão significativa como aluna e também como professora, pois sempre tive boa relação com meus professores e alunos.

Os resultados da pesquisa contribuíram para meu entendimento acerca dos motivos de tal conflito vivido na escola, e se não me trouxe soluções em curto prazo, ao menos, me ajudou a compreender a ocorrência de tal fenômeno (SILVA, 2009). Em 2010, com o incentivo de minha orientadora do mestrado Profa. Dra. Luciana Maria Giovanni e da Profa. Dra. Alda Junqueira Marin ingressei no doutorado da PUCSP para pesquisar a dimensionalidade da profissão docente por meio da análise da identidade de professores em exercício. Os resultados de tal investigação me trouxeram a certeza, provisória é verdade, do quanto a atuação de professores e do processo de escolarização podem ser decisivas na vida pessoal e profissional do sujeito social (SILVA, 2014). São marcas que a experiência põe à prova cotidianamente.

A complexidade dessa experiência reside, por um lado, justamente no caráter sempre inacabado das disposições, já que o sujeito age sobre o que lhe acontece (LAHIRE, 2004), porém esse movimento não pode ser entendido de maneira dissociada da ordem de razões, da qual ele tira o sentido de suas ações, e dos contextos de inserção, consciência e vontade individuais (BOURDIEU, 2003). Essa dinâmica revela uma relação em parte indeterminada entre o modo como o profissional se vê e o modo como é visto, por sua inserção em um meio social, fato que constitui e reconstitui sua identidade profissional (DUBAR, 2005).

Já de posse dessa metamorfose gradativa, em 2013, passei a atuar como professora no curso de Pedagogia da Universidade Nove de Julho nas modalidades presencial e a distância, experiência rica de uma vivência que, aos poucos, norteou os caminhos que quero percorrer como professora e pesquisadora. Em 2014, saiu minha aposentadoria na rede estadual de ensino e passei a atuar apenas na Universidade. Em 2015, trabalhei num curso de pós-graduação na FMU como professora convidada para a disciplina de mediação pedagógica e, no segundo semestre, ministrei duas disciplinas da pós-graduação em Docência para o ensino superior na Faculdade Sumaré. Para essa mesma turma, fui convidada a orientar o TCC com o projeto "Identidade e Memória". Desse trabalho resultam 13 artigos sobre a temática que envolve o processo de recuperar as memórias escolares para melhor compreender a prática pedagógica, publicado em revista eletrônica da instituição. 
Após desenvolver esse trabalho, recebi o convite para atuar como professora da graduação em Pedagogia da Faculdade Sumaré, ao mesmo tempo em que estabeleço conversas sobre a escrita de projeto para o pós-doutoramento na Universidade de São Paulo com a Profa. Dra. Paula Perin Vicentini, com vistas a aprofundar discussões sobre a temática da identidade e memória como recurso para uma autorreflexão e dimensionamento das práticas no exercício profissional.

O projeto do pós-doutoramento acaba adiado em função de compromissos profissionais que subtraem o tempo necessário para sua realização, sempre nos lembrando do quanto as condições objetivas têm peso decisivo nas escolhas que fazemos.

Em 2018, desenvolvi trabalho no curso de pós-graduação lato sensu da Universidade Salesiana - Unisal - campus Lorena, com o módulo de avaliação. Discutir o tema com profissionais de diferentes áreas de atuação se mostrou uma contribuição importante e relevante para o entendimento de diferentes perspectivas da docência. Atualmente, trabalho na Escola de Aplicação da Universidade de São Paulo EAFEUSP - uma experiência desafiadora ao impelir, todos os dias, o exercício da articulação teoria e prática no desenvolvimento de conteúdos e projetos interdisciplinares. Atuo também nas Faculdades Integradas Potencial - FIP Campus Cotia - com as disciplinas pedagógicas nos cursos de Licenciatura: Letras e Pedagogia. Nesse espaço de atuação, encontrei rico espaço de discussões e troca de experiências que geraram uma postura de encorajamento para a promoção de mudanças significativas e necessárias no que se refere à formação de professores.

Passo agora a um breve relato sobre minha experiência na pós-graduação e como essa trajetória contribuiu para que pudesse olhar para minha prática e para o trabalho realizado na escola com lentes mais compreensivas e tolerantes.

\section{A EXPERIÊNCIA DA PÓS-GRADUAÇÃO}

Em 2007, comecei o mestrado da PUCSP, ao mesmo tempo em que assumi a direção da escola estadual onde trabalhava desde 1986. Penso que no momento em que vejo minha admiração pela profissão docente agonizar diante dos desafios vividos na escola, quando passei a ter clareza de que continuar atuando no espaço escolar sem encontrar caminhos possíveis e menos ainda, sem esperança de solução para que 
voltasse a sentir aquele prazer, aquela alegria de estar na escola, enchi-me de coragem para ingressar na pós-graduação e buscar as respostas que pareciam escapar à minha compreensão.

Cheguei ao extremo dessa desesperança quanto percebi que sentia vergonha de assumir meu lugar na docência, criticava minha atuação e ao mesmo tempo não encontrava resposta para transformar essa sensação que desestimula pessoal e profissionalmente. Essas representações da escola e da atuação profissional foram, sem dúvida, potencializadas no momento em que assumi a gestão da escola. Quando os impasses, desafios e conflitos chegavam diante de mim, por muitas vezes, sentia a impotência, a frustação e a tristeza por não possuir respostas possíveis, ao mesmo tempo em que desejava propor intervenções, contribuir, compreender.

Quando nosso espaço de trabalho é a sala de aula, ainda temos uma autonomia relativa para tentar escapar de algumas armadilhas que nos arrastam para o fracasso, mas quando assumimos a gestão temos a sensação de que não há mais alunos diretamente ligados à nossa prática e escolhas profissionais, no entanto, gradativamente vai se construindo uma percepção de que todos são nossos alunos, de que todos os professores precisam de nós, de que os funcionários dependem de uma clareza no norteamento de ações, de que os pais e a comunidade esperam de nós decisões pertinentes que superem ou minimizem os desafios que surgem incessantemente na rotina das escolas.

Aliada a toda essa problemática, o gestor escolar ainda necessita gerenciar toda a parte administrativa da escola, uma tarefa que é, também, bastante complexa na realidade da escola e da qual não se pode descuidar sob pena de comprometer recursos, proventos e processos que se apresentam todos os dias como urgências que não podem ser ignoradas.

A partir desse cenário, uma professora de escola pública que iniciou a carreira docente aos 18 anos e que sempre vibrou muito dentro do ambiente escolar, de tal forma que o papel social de aluna e professor parecem se fundir num continuo que sempre representou prazer e realização pessoal e profissional, adoece diante da impotência para encontrar saídas que recuperem esse imaginário.

Diante desse panorama, fui buscar o remédio na pós-graduação e minha trajetória nesse período representou um divisor de águas para que me reencontrasse com a docência, para que fizesse as pazes com minha prática, para que encontrasse 
argumentos teóricos e metodológicos que fossem capazes de construir novos sentidos à minha trajetória profissional.

No início do processo, foi perceptível as lacunas de formação de que eu precisava superar, mas abracei esse desafio com muito empenho, pois a cada dia sentia o descortinamento de outra perspectiva para interpretar o trabalho na escola. Fui, paulatinamente, construindo disposições traduzidas em lentes mais tolerantes para enxergar a rotina da escola, derrubando julgamentos, retomando a autoestima, recuperando sentidos para o exercício profissional.

Essas disposições construídas pelo sujeito possuem relação com o mundo, o indivíduo não se produz isolado da sociedade, ele é uma realidade social caracterizada por sua complexidade disposicional, que se manifesta na diversidade dos domínios de práticas ou cenários nos quais insere suas ações (LAHIRE, 2004).

Assim, na pesquisa sobre a relação professor-aluno no espaço de sala de aula à luz dos intervenientes presentes na cultura que permeia essa interação, foi possível inocentar professores, alunos e gestores, por meio da compreensão de que existe todo um ethos cultural que envolve essas relações práticas, além de um sistema pautado em políticas educacionais que pressionam posições contraditórias dentro de um processo complexo e antagônico.

Em 2010, ingressei no doutorado para pesquisar a dimensionalidade da profissão docente por meio da análise da identidade de professores em exercício, para tanto, a escolha metodológica pauta-se na construção e análise de retratos sociológicos desses profissionais. Os resultados de tal investigação me trouxe a certeza, provisória é verdade, do quanto a atuação de professores e do processo de escolarização podem ser decisivas na vida pessoal e profissional do sujeito social, ao considerar as disposições construídas no processo de socialização e que, gradativamente configuram um habitus que, consciente ou inconscientemente, norteia nossas ações.

Ao concluir essa longa trajetória de desconstrução, o que leva a deixar cair por terra muitas crenças pautadas no senso comum, pude reconstruir outra perspectiva da profissão docente e reavaliar minhas posições profissionais. Algumas questões que antes julgava insolúveis passo a compreender que, na verdade, são resultado de mecanismos políticos que realimentam uma estrutura escolar calcada em objetivos macroestruturais e, portanto, nenhuma contribuição trazem para a construção de uma escola democrática. Esse entendimento me fez ver que o que acontece na cultura que se 
perpetua na escola não é destino, mas contingência, ou seja, há toda uma lógica para que as coisas não mudem. Tal fenômeno é conveniente para que se mantenha uma ideologia estatal que anuncia processos democráticos e participativos sem, no entanto, prever condições efetivas para sua concretização.

Outra questão macro envolvida tem a ver, por um lado, com a formação inicial de professores e, por outro, com o modo como o capital cultural trazido pelos alunos é considerado pela escola. A formação inicial de professores parece não dar conta dos desafios enfrentados na realidade da atuação profissional e sobre isso, há aspectos ligados ao modo como as instituições promovem essa formação, bem como em relação às orientações legais sob as quais as instituições formadoras também estão subordinadas.

É importante ainda considerar que, o público que busca os cursos de formação de professores enfrentam desafios de diferentes ordens - qualidade da educação básica, parcos recursos financeiros, tempo disponível para dedicação ao curso etc. - para chegar ao final da trajetória formativa, e isso acaba por trazer consequências significativas no exercício da profissão, fatores que, sem dúvida, também representam desafios para as instituições formadoras.

Esses desafios oriundos das condições objetivas da formação inicial implicam diretamente a prática profissional desses professores que, como aponto acima, tomam de maneira distorcida o capital cultural trazido pelos alunos ao não considerar o contexto de inserção desse público, as experiências vividas como parte das metodologias de ensino, o que leva, por fim, ao desenvolvimento de um trabalho voltado à práticas homogeneizadoras que, em nada contribuem ao atendimento diversificado que deveria ocorrer em nossas escolas.

Pior que chegar a essa conclusão é ter a clara percepção de que, grande parte dos professores em exercício nas nossas escolas, não têm clareza desses entraves e julgam que na prática, o trabalho realizado é satisfatório e os alunos não correspondem ao esperado pelo universo escolar. A culpabilização, na maioria das vezes, recai sobre o aluno e este, por sua vez, não tem quem o defenda, o que os leva a acreditar que a escola e seus mecanismos excludentes é boa e eles é que são fracassados por terem diante de si uma escola que não considera suas necessidades e expectativas.

Na prática, isso significa mudar apenas nome e data nos planejamentos anuais, não refletir teoricamente sobre o trabalho desempenhado em sala de aula, não planejar 
as aulas, afinal o tempo reduzido impede tais ações, negativas em relação à participação nos colegiados, à construção do Projeto Político Pedagógico, entre outros.

Pude perceber, após minha experiência na pós-graduação que, na verdade, professores e alunos vivem, na maioria de nossas escolas, experiências que não permitem avançar rumo à formação almejada. O discurso de uma escola democrática que busca formar alunos que exerçam uma cidadania plena e efetiva não se coaduna à realidade que encontramos nas escolas e que são relatadas não apenas pela minha experiência no período em que atuei como gestora de escola pública, mas também nos resultados de pesquisas divulgados todos os dias pelos pesquisadores em educação.

São dados que expõem uma realidade perversa; no entanto, quando se vive a experiência de professor-pesquisador é possível tomar ciência de tais mecanismos e, assim, reinterpretar as demandas e desafios que a educação básica enfrenta hoje.

Atuar hoje no ensino superior no curso de Pedagogia, a par de todos esses mecanismos excludentes e perversos que estão presentes nas entrelinhas das políticas educacionais vigentes em nosso país, faz com que eu busque construir um discurso que contemple essas questões e tenha um posicionamento mais tolerante frente aos desafios enfrentados pelos alunos e alunas e um olhar que busca compreender toda a problemática que envolve não só a profissão docente, mas também os desafios da formação em função dos públicos presentes nos cursos de formação de professores.

Esse deciframento de ações, ultrapassa as intenções objetivas, os projetos conscientes, individuais e coletivos; vai além ao relacionar diretamente práticas e propriedades inscritas na situação contextual, sem esquecer que as relações interpessoais são relações de indivíduo a indivíduo só aparentemente, pois eles transportam com eles, em todo tempo e lugar, a posição presente e passada na estrutura social, então não é indivíduo e indivíduo que se relacionam, mas habitus, disposições, pessoas sociais (BOURDIEU, 2003).

Parece pertinente dizer que hoje, a partir da contribuição de estudos na pósgraduação, vejo toda a realidade diante de meus olhos como contingência de processos políticos e econômicos excludentes e por isso mesmo, faço outra leitura acerca das demandas colocadas para a formação de professores. Entender que nossas dificuldades não são irreversíveis, mas que podem ser transformadas a partir de processos formativos que permitam exercício profissional mais equânime alimenta e realimenta minha prática, mesmo sabendo que podemos estar diante da utopia anunciada, não posso me 
furtar a encarar esse desafio. Hoje reinterpreto toda dinâmica envolvida no campo educacional à luz de estudos teóricos que, ao contrário do que muitos acreditam, muito elucidam o entendimento da prática.

É possível dizer, portanto, que a construção do conhecimento, atrelada a uma prática reflexiva, é capaz de mudar o discurso, o olhar, a interpretação e a leitura de mundo produzida por professores em exercício. Parece, ainda, urgente reiterar como esse processo transforma o sujeito não apenas no âmbito profissional, mas também promove amadurecimento pessoal e dá à quem o realiza condições de compreender o cenário, a sociedade e a própria vida em movimento.

Como a interpretação, o sentido e o discurso docente podem promover mudanças, à guisa de conclusão, a Professora Márcia Maria Martinelli Elias, nos brinda, de uma perspectiva possível, considerações sobre o olhar acerca do papel dos sentidos na interpretação de contextos como componente de transformação da realidade.

\section{PRÁTICAS DOCENTES RESSIGNIFICADAS}

Quando o professor vai à busca de novos conhecimentos científicos, ele lança, sobre sua prática pedagógica, um olhar crítico e torna-se capaz de interpretá-la, avaliá-la e, se necessário, recriá-la. De modo que novos saberes ampliam não só a atuação pedagógica do professor, como também sua relação com os alunos e sua percepção do cenário social e político que estão, intrinsecamente, ligados à educação.

As relações dialógicas - fenômeno bem mais amplo do que as relações entre as réplicas do diálogo expresso composicionalmente - são um fenômeno quase universal, que penetra toda a linguagem humana e todas as relações e as manifestações da vida humana, em suma, tudo que tem sentido e importância (BAKHTIN, 1992, p 42).

Ter o domínio do conhecimento científico, muda a visão e o repertório do docente. Seu discurso se converte em outro; as dificuldades, inerentes à prática docente, passam a ser entendidas como situações que podem ser transformadas, uma vez que o professor concebe a escola sem o véu da perfeição, mas com os olhos voltados à realidade.

O saber científico é o que legitima a prática docente, o professor, ao se sentir compelido a ampliar suas habilidades profissionais, desenvolve, também, sua vida 
pessoal o que gera mudanças significativas em seu modo de pensar e de agir na docência.

Nessa perspectiva, a procura por novos conhecimentos implica mudanças na prática, no discurso e na organização didática das aulas, visto que a pós-graduação leva o professor a apreender novos conceitos, se apropriar deles e transformá-los em ações pedagógicas voltadas ao aluno, à escola e à comunidade.

Torna-se evidente que o professor, ao optar pela educação continuada, reflete sobre sua prática docente, identifica as lacunas a serem preenchidas com as novas teorias, constata as dificuldades que irá encontrar ao implementar mudanças; porém é capaz de enfrentar os desafios exigidos, pois vislumbra como será seu ponto de partida, seu percurso e seu permanente caráter provisório. Por isso, Bakhtin afirma que "a compreensão responsiva do conjunto discursivo é sempre de índole dialógica" (BAKHTIN, 1992, p. 332).

A pesquisa conduz o professor a ampliar não somente o saber dentro da sua área de atuação, vai além, uma vez que ela amplifica seu modo de conceber o mundo e, assim, o docente apropria-se das necessidades ligadas à docência e gestão escolar.

Essa busca por novos saberes é consequência da necessidade de apossar-se de novas possibilidades, como de incluir na prática docente novas metodologias. Enfim, quando o professor se angustia em seu fazer docente e se sente desmotivado frente aos desafios, muitos encontram suporte na pesquisa e passam, a partir daí, a compreender a realidade escolar, para depois superar paradigmas, ressignificando, assim, esse fazer, por meio de atitudes mais assertivas à sua prática.

Tal processo representa um trabalho de desconstrução, uma vez que as convicções do professor são substituídas por novas perspectivas e a prática docente, nesse momento, passa a ser construída sob um novo viés, porque ainda que a situação esteja estagnada dentro do ambiente escolar, o professor revestiu-se de um novo repertório. Ele deixa de lado a sua maneira de pensar e constrói novas disposições, de forma mais consciente e próxima da sua realidade sem deixar, no entanto, de imprimir à prática o rigor do conhecimento acadêmico.

Um professor, ao se tornar pesquisador, agrega à sua prática docente um modus operandi diverso, reveste-se de um novo discurso, uma vez que adquiriu, por meio dos novos conhecimentos, uma outra forma de pensar e enxergar a realidade na educação, assim, a maneira com que lida com as contingências não são as mesmas. Ele se apossou 
do saber e, assim, é capaz de interpretar os desafios e vislumbrar outros caminhos possíveis. Está aberto às mudanças e à superação de paradigmas, com foco no desenvolvimento do aluno e no próprio desenvolvimento científico.

Ressalta-se que o docente, ao apropriar-se de uma nova visão das suas necessidades, pressupõe que estas são reversíveis, pois é capaz de transmutá-las. Assim, quando o professor enxerga a educação à luz dos conhecimentos científicos, exerce sua função plena de educador, deixa de ser um executor de tarefas, faz leituras mais assertivas do cotidiano e forja ações voltadas para a articulação entre teoria e prática, de modo que fatos e fenômenos sejam abordados à luz dessa concepção fulcral para a educação.

\section{REFERÊNCIAS}

BAKHTIN, M. Os gêneros do discurso (1952-1953). In: Estética da criação verbal. São Paulo: Martins Fontes, p. 277-326, 1992.

BOURDIEU, P. A sociologia de Pierre Bourdieu. São Paulo: Olho D’água, 2003.

BOSI, E. O tempo vivo da memória. São Paulo: Ateliê Editorial, 2003.

CUNHA, M. I. Conta-me agora! As narrativas como alternativas pedagógicas na pesquisa e no ensino. Rev. Fac. Educ. vol. 23, n.1-2, São Paulo, Jan./Dec. 1997.

DUBAR, C. A socialização: construção das identidades sociais e profissionais. São Paulo: Marins Fontes, 2005.

LAHIRE, B. Retratos Sociológicos: Disposições e Variações Individuais. Porto Alegre: Artmed, 2004.

SARTRE, J. P. O ser e o nada. Disponível em:

https://meuartigo.brasilescola.uol.com.br/filosofia/o-existencialismo-sartre.htm.

SILVA, L. M. da. A relação professor-aluno: traços culturais presentes na interação em sala de aula. Dissertação de Mestrado. Pontifícia Universidade Católica de São Paulo: PUCSP, 2009.

SILVA, L. M. da. As formas identitárias nos contextos de trabalho: Uma análise da profissionalidade docente. Tese de doutorado. Pontifícia Universidade Católica de São Paulo: PUCSP, 2014.

SOUZA, E. C. de; SOUSA, C. de; CATANI, D. B. La reserche (auto) biographique et l'invention de soi au Bresil. Colloque International (1986- 2007) Le Biographique, la réflexivité et les temporalités. Articuler Langues, cultures et formation. Université FrançoisRabelais, 25-27 juin 2007, Tours-França. 


\title{
O CEFAM E A FORMAÇÃO INICIAL DE UMA GERAÇÃO DE PROFESSORES
}

\section{CEFAM AND THE INITIAL TRAINING OF A GENERATION OF TEACHERS}

\author{
Diego Moreira ${ }^{12}$
}

\section{RESUMO}

O artigo apresenta a trajetória de formação e profissionalização dos egressos do CEFAM (Centros Específicos de Formação e Aperfeiçoamento para o Magistério), numa leitura pessoal da história de vida e percurso formativo. Retoma momentos da vida e conecta com a história do magistério e do movimento de fundação do CEFAM no Brasil e em São Paulo.

Palavras-Chave: CEFAM. Magistério. Trajetórias. Profissionalização.

\section{INTRODUÇÃO}

O artigo versa sobre a trajetória de formação e profissionalização a partir do ingresso no magistério do CEFAM (Centro Específico de Formação e Aperfeiçoamento para o Magistério).

Ingressar no curso do magistério aos treze anos de idade e experimentar uma formação integral por quatro anos no período da adolescência, foi um percurso definidor para a vida. Compreender esse processo de formação e como a escola era organizada para entregar para a sociedade os profissionais da educação que atendessem todas as expectativas e demandas da população.

Num relato de vida, o texto procura apresentar como as políticas educacionais são importantes para que jovens se profissionalizem e tenham condições de permanecer na escola, bem como, a relevância de um projeto pedagógico lúcido e definido faz diferença para formar professores.

E conclui sobre as marcas dessa escola na vida e na profissionalização, na constituição da própria identidade e visão de mundo. A escola que me formou professor e a escola que me acolheu como profissional foram definidoras da minha história.

${ }^{12}$ Doutorando e Mestre em Educação pela PUCSP. Graduado em História e Pedagogia. Há mais de 20 anos atua na carreira docente, com experiência desde o ensino fundamental até a Pós Graduação, em redes públicas e privadas. É pesquisador na área de formação de professores e Gestores. Leciona na Pós graduacão nas áreas de Educacão e Gestão de Pessoas. 


\section{O VESTIBULINHO PARA O INGRESSO NO CURSO DE MAGISTÉRIO}

Ingressei no magistério sem ter clareza sobre o que significava fazer um curso de ensino médio numa escola chamada CEFAM.

Morador da zona leste da capital paulista, filho de pais trabalhadores que não tiveram acesso ao ensino superior, sempre fui estudante de escola pública estadual e lá pelos idos de 1996 cursava a $8^{\text {a }}$ série do ensino fundamental na E. E. Caetano Zamitti Mammana e concomitantemente fazia um cursinho preparatório para o vestibulinho, fortemente estimulado pelos meus pais para tentar ingressar nas escolas técnicas paulistas ou na tão disputada escola técnica federal.

A partir da indicação de alguns professores, os amigos da turma me chamaram para fazer inscrição para um vestibulinho numa escola de magistério em São Miguel Paulista. Não sabiam me explicar direito sobre o curso, mas estavam empolgados em razão de uma bolsa de estudos que poderiam receber.

Marcamos para uma tarde logo após a saída das aulas e percorremos cerca de cinco quilômetros a pé até a E. E. Eng ${ }^{\circ}$ Hugo Takahashi - CEFAM II para realizar a inscrição. Dentre os oito ou nove amigos da turma que realizaram a prova, apenas uma amiga e eu fomos classificados para a matrícula.

Eram disponibilizadas 120 vagas para o ingresso no primeiro ano do Ensino Médio e especialmente no vestibulinho de 1996 foram realizadas mais de 1400 inscrições para a prova.

Considerando as outras possibilidades de curso e distância para as escolas no centro da cidade de São Paulo, optei por cursar o magistério do CEFAM no bairro de São Miguel Paulista, que era a opção mais próxima da minha casa.

Reitero, não tinha clareza sobre o que significava uma escola de magistério de período integral. Só tínhamos as informações dadas pelos professores que era uma ótima escola.

\section{O COTIDIANO NO CEFAM}

O ingresso no primeiro ano do ensino médio era marcado por uma reunião que a coordenadora pedagógica conduzia junto com corpo docente e direção. No pátio da 
escola a presença de todos os responsáveis pelos estudantes era obrigatória e possuía um clima de tensão diante de tanta novidade se avizinhava.

As orientações burocráticas sobre a matrícula, o recebimento da bolsa de estudos e a rotina escolar eram passadas com grande formalidade, a reunião era sisuda e bem institucional. A coordenadora pedagógica sempre muito enfática e rigorosa fazia questão de deixar claro o que significava ingressar naquela escola e do compromisso que os ingressantes precisavam ter com a carreira. Os aprovados que não desejavam ser professores eram estimulados abertamente a não realizar a matrícula sob o risco da devolução dos valores recebidos nas bolsas de estudos.

Lembro de retornar para casa conversando com a minha mãe sobre o rigor e o comprometimento de estudos que a escola exigiria. Muitos documentos assinados, muitas recomendações de comportamento e claro, um mundo novo que se abria ao iniciar as aulas. Uniforme, alimentação, carteira de estudante, transporte, horários...cada detalhe que o período exigiria.

Para além das dinâmicas institucionais e do rigor técnico da gestão, o dia a dia do CEFAM nos apresentava mais cores e momentos de construção de muitos afetos. Já no primeiro mês de aula descobrimos como o funcionamento da escola acontecia na manutenção do "status-quo" interno. Uma dinâmica de organização já estabelecida e que não estava escrita em nenhum regimento interno.

Os $4^{\circ}$ anos do curso eram as turmas admiradas e exemplos a ser seguidos. Algumas alunas já faziam faculdade no período noturno e estágios durante o dia, assim tinham horários mais flexíveis e gozavam de alguns acessos e privilégios que os demais ainda não possuíam. Os temas sobre vestibulares e concursos rondavam as conversas delas.

Já pareciam professoras, andavam com muitos livros e estavam sempre estudando. Também tinham os times mais fortes nos campeonatos esportivos. Para um menino com treze anos de idade, aquelas eram as garotas mais bonitas e inalcançáveis do colégio.

Os $3^{\circ}$ anos eram os aspirantes ao modo de vida do $4^{\circ}$ ano, contudo ainda não gozavam dos mesmos privilégios. As tradicionais festas da escola eram organizadas pelas turmas dos terceiros anos, sendo assim, todo o trabalho de organização que os estudantes estavam envolvidos passava essencialmente pela capacidade de articulação 
desta série. As feiras, seminários e festas eram o passaporte para os privilégios na série seguinte.

Os $2^{\circ}$ anos eram os responsáveis pelas apresentações, decoração e organização da cozinha. Os eventos eram todos decorados sob a orientação e encomenda dos $3^{\circ}$ anos. Claro que sob o olhar crítico e avaliativo dos $4^{\circ}$ anos.

Aos $1^{\circ}$ anos ficava a parte de organização de cadeiras e limpeza. Toda a limpeza dos eventos era de nossa responsabilidade.

Não sei quem inventou essa divisão, ocorre que ela funcionava bem, mesmo com muitos questionamentos da hierarquia o grupo de docentes defendia esse modelo, no entanto, nas organizações estudantis como o grêmio e os campeonatos esportivos a divisão de classes (sem trocadilhos marxistas) era amplamente posta à prova.

O clima escolar era muito acolhedor, mesmo com carga horária grande, os docentes mantinham posturas de rigidez e acolhimento. Algumas aulas possuíam dinamismos que nunca tínhamos experimentado anteriormente e a vivência diária por muitas horas estimulava apoios e amizades verdadeiras.

O CEFAM de São Miguel possui 10 salas de aulas e entre 1995 até seu encerramento em 2005 ficou no prédio da E.E. Eng ${ }^{\circ}$ Hugo Takahashi. A estadia do CEFAM funcionava como um empréstimo da escola, pois em São Paulo o projeto nunca teve prédio próprio. Com cerca de 400 estudantes, a maioria esmagadora era de meninas. Entre 1997 e 2000 éramos 18 meninos nesse universo feminino.

O dia a dia do magistério era bem puxado, fazíamos 10 aulas diárias, entramos na escola às $07 \mathrm{~h}$ e saímos às $17 \mathrm{~h} 40$ minutos. O currículo era organizado em parte comum com as disciplinas do ensino médio e parte específica com as disciplinas do magistério. O curso possuía 4.000 horas somadas mais 720 horas de estágios supervisionados.

No primeiro ano do curso além das disciplinas de núcleo comum tínhamos disciplinas como História da Educação, Sociologia da Educação, Psicologia da Educação e Filosofia da Educação que pertenciam ao currículo específico do magistério. Este destaque ajuda a nos dar pistas para entender como essa geração de professores foi formada lendo autores densos desde muito cedo. Com idades entre treze, catorze e quinze anos, tínhamos contato com textos de Paulo Freire, Saviani, Chauí, Milton Santos entre outros. 
Até hoje guardo um exemplar de Pedagogia da Autonomia que ganhei no segundo semestre de 1997, imagina que tinha acabado de completar catorze anos. Isso aconteceu com toda a geração de professores que cursou o magistério no CEFAM.

Mesmo com as limitações naturais da maturidade, era nos dado acesso aos escritos de Wallon, Vygotsky e Piaget e discussões acaloradas sobre os rumos da política nacional. Lembro que no final do $1^{\circ}$ ano discutimos os textos de Marx com a turma de amigos que estavam nas séries posteriores.

O dia a dia no CEFAM não deixava dúvida sobre a formação para o exercício da profissão docente. Toda a organização da rotina distribuída em todas as séries essa finalidade era explícita e inquestionável.

No segundo ano do magistério eram iniciados os estágios de observação. E neste momento o conhecimento adquirido no primeiro ano do curso servia de base para os debates nas aulas pós estágio. Para os estágios também era exigido uma excelente postura profissional, de modo que o comportamento dos estagiários nas escolas parceiras que nos recebiam devia manter sempre postura correta de acordo com as orientações recebidas pelas professoras.

Por mais que a estrutura fosse adaptada para o curso integral, o cotidiano na escola de magistério possuía peculiaridades da vida comum, como a organização dos banheiros e da alimentação.

A maioria dos estudantes levava marmita para se alimentar e nem sempre a estrutura reservada para esse momento atendia o conjunto de mais de 400 alunos, dessa forma, constantes manifestações, reclamações e até um dia que decidimos realizar uma paralisação das aulas para exigir a melhoria das condições de permanência na escola.

O terceiro ano do curso era permeado pelas questões dos estágios, das aulas de metodologia de ensino e pelo vestibular. Intensos estímulos eram feitos pelos docentes para que todos se comprometessem na continuidade de estudos na universidade, de preferência pública.

As aulas de metodologia de ensino eram leves e bem dinâmicas, lembro que tínhamos professoras que já estavam concluindo o mestrado e todas possuíam ampla experiência com a alfabetização.

Naquele tempo, para nossa geração de professores o grande tema da formação eram os processos de alfabetização, a educação infantil ainda não fazia parte da 
secretaria de educação, e o desafio formativo do CEFAM era formar bons alfabetizadores. E assim era feito.

No quarto ano do curso já fazíamos estágios de regência e voltávamos para a escola para as disciplinas pedagógicas e algumas do currículo comum que eram deixadas para esse momento com vistas aos vestibulares. Nesse momento do curso a apresentação de concursos públicos e possibilidades de ingresso na carreira também eram constantes.

Um ponto muito marcante no curso do CEFAM de São Miguel Paulista foram as visitas técnicas ou excursões como se chamava à época. Muitos passeios culturais, aulas na cidade, eventos, feiras e seminários.

Lembro de ouvir o Prof. Marcio Pochmann pela primeira vez num seminário na Secretaria da Fazenda do Estado de São Paulo num evento organizado pelo professor de Geografia quando estávamos no segundo ano do curso.

Viagens para Barra Bonita, nascente do rio Tietê, exposições de arte na cidade e bienal do livro eram comuns no cotidiano das aulas. Há muitas exposições no MASP, Pinacoteca e os mais variados museus da cidade. O estímulo ao conhecimento e ampliação do repertório cultural fazia parte do nosso currículo no CEFAM.

Aos dezesseis e dezessete anos de idade o CEFAM criava em nós uma redoma de proteção. Era escola de tempo integral com uma bolsa que garantia a permanência no curso e a clareza do objetivo da escola que nos dava muita segurança para o aprofundamento dos estudos e para o amadurecimento na adolescência.

Mais que um currículo bem estruturado, o CEFAM funcionava como nossa segunda casa. Passávamos 10 horas por dia em convívio com colegas e professores, construímos vínculos de afeto e experimentamos muitas histórias. Conflitos, amores, afetos e desafetos, sonhos revolucionários e muitos medos e incertezas.

Ao final do quarto ano do magistério, a prefeitura de São Paulo abriu concurso público para ingresso. Lembro de usar o dinheiro que recebia da bolsa de estudos para pagar a inscrição, fomos em grupo pagar a taxa no banco.

Cheios de dúvidas sobre a faculdade que seguiríamos, sobre as possibilidades de trabalho que nos esperava e também cheios de esperanças sobre o término do curso. Assim fizemos a prova do concurso.

Sem nenhuma experiência, praticamente toda a turma passou. No dia da escolha de vaga encontramos muita gente querida da turma e de turmas anteriores. 
Ingressei no município de São Paulo nas primeiras chamadas e comecei a lecionar numa escola muito próxima da casa em que meus pais moravam.

\section{O INÍCIO DO EXERCÍCIO DO MAGISTÉRIO}

Entre o término do curso do CEFAM e a chamada para assumir o cargo na Prefeitura de São Paulo decorreram longos oito meses. Nesse ínterim dei aulas particulares em casa e comecei a lecionar como professor eventual na escola estadual chamada Neydy de Campos Melges na periferia do Itaim Paulista e divisa com Ferraz de Vasconcelos.

Em meados de 2001 as escolas particulares dificilmente contratavam professores homens para os anos iniciais, sendo assim aos dezessete anos minhas chances de emprego fora do setor público eram diminutas, quase nulas. Entreguei muitos currículos e cheguei a ser chamado por uma escola privada do bairro para ser inspetor de alunos, recusei, pois, eu tinha clareza que queria lecionar.

Ingressei no curso de História assim que concluí o magistério, então cursava a faculdade enquanto trabalhava como professor eventual e particular com aulas de reforço para crianças do bairro.

Ao ser chamado no concurso do Município de São Paulo escolhi uma escola na região em que moravam e fiquei por menos de um mês na EMEF Sem. José Ermírio de Moraes até ser transferido para a EMEF Virgílio de Mello Franco, manteve as aulas como professor eventual no estado com o acúmulo de cargo na prefeitura e estudava no período da noite.

Foi nesse tempo da carreira que aprendi a ser professor.

Ninguém da minha família teve trajetória na Educação, meu pai foi metalúrgico e segurança e minha mãe enfermeira. Não tinham como me orientar sobre os ritos das atribuições de aula, ou mesmo sobre os desafios das escolhas de escola e jornadas de trabalho. No início da carreira tive alguns amigos da comunidade religiosa que frequentava que me deram conselhos preciosos de qual caminho seguir. E foram esses conselhos que segui.

Professor Marcelo Ferreira e Professora Vanessa Silva, ele formado em história me orientou e me inspirou para escolher o mesmo curso, pois sabendo da minha vontade em cursar Ciências Sociais, me alertou sobre o número pequeno de aulas na rede 
estadual. A Vanessa, professora de Língua Portuguesa e esposa do Marcelo, me deu valiosos conselhos sobre os processos de atribuição na prefeitura e no estado. Sempre generosos me socorreram muitas vezes quando precisava de ajuda para tomar decisões, inclusive financeiramente.

Nesse período, na ocasião do concurso do Estado de São Paulo, eu estava inscrito para prestar a prova. No entanto, sem dinheiro também me inscrevi para trabalhar como fiscal na aplicação do concurso. Não prestaria a prova do concurso para trabalhar. Os dois amigos, Marcelo e Vanessa, ao descobrirem isso na véspera do certame, me ofereceram o dinheiro que receberia pelo dia do trabalho e exigiram que eu fosse prestar o concurso. Tomei um sermão deles.

Orgulhoso, nessa ocasião, não aceitei ajuda financeira e fui fazer a prova. Meu número de acertos nas questões objetivas foi muito alto e gabaritei a dissertativa. Me efetivei na rede estadual na primeira chamada do concurso. Foi a aprovação nesse cargo que me possibilitou ingressar no mestrado posteriormente, no programa chamado Bolsa Mestrado.

Os primeiros cinco anos da minha carreira profissional se deu concomitantemente a minha formação universitária. Enquanto fazia História lecionava na Prefeitura e no Estado. Esse tempo foi muito marcante na minha trajetória.

Na EMEF Virgílio de Mello Franco, fui acolhido com muito carinho pelo grupo experiente de professoras. Me ensinaram muito. Eram pacientes com os meus afãs sindicais e revolucionários e generosos no convívio.

Um grupo dessas professoras já estavam na rede municipal a muito tempo e costumavam brincar comigo que o Secretário de Educação delas tinha sido o Paulo Freire. Talvez elas não tenham a dimensão do quanto esse processo de acolhimento e estímulo fez bem para minha formação profissional.

Um ponto muito importante nesse período e que vale ser lembrado, é que nesse tempo a Prefeitura de São Paulo aceitava como parte da pontuação para o processo de evolução funcional os comprovantes de aprovações em concursos públicos. As professoras que me acolheram eram profissionais sábias, engajadas politicamente e leitoras das bibliografias dos concursos. O cotidiano dessa escola que iniciei minha carreira era marcado por debates sobre legislação, conceitos teóricos e metodológicos. Isso contribuiu muito para que eu continuasse aprendendo, prestando concursos e obtendo êxito nas aprovações. 
Do mesmo modo, ao terminar o curso de História, ainda muito jovem com 21 anos, foram essas professoras que me aconselharam fazer Pedagogia e por meio delas que conheci a Fundação Escola de Sociologia e Política que cursei a especialização ao mesmo tempo que fazia Pedagogia.

Esse trajeto faz sentido na compreensão da importância da política pública educacional, pois minha formação e trajetória profissional passam invariavelmente pela ação do estado. No processo de formação como estudante do magistério em escola pública e no ingresso na carreira por meio de concurso público no município e no estado. As duas principais marcas de trajetória só foram possíveis em razão da ação de políticas do estado.

\section{UM BREVE CONTEXTO HISTÓRICO DE CRIAÇÃO DO CEFAM.}

Para compreender a minha trajetória profissional - e parte da trajetória de uma geração de professores formados pelo CEFAM - e para entender as experiências vividas como professor no início da carreira é fundamental que façamos um recorte histórico sobre o contexto de criação do CEFAM.

A história da minha trajetória de formação e início da profissionalização só pode ser lida por meio do entendimento e conhecimento histórico das decisões políticas das décadas anteriores. A ação do estado foram marcos para minha escolarização, profissionalização, ingresso e permanência da carreira docente.

O Centro Específico de Formação e Aperfeiçoamento para o Magistério CEFAM foi um projeto criado na esteira do esvaziamento e das críticas sobre a lei 5692/71 que criava as Habilitações Específicas para o Magistério que desmontaram a o Curso Normal e toda historicidade e identidade já construída em décadas anteriores.

Conforme afirma Tanuri (2000, p. 80):

A lei 5692/71 que estabeleceu diretrizes e bases para o primeiro e o segundo grau, transformou-o numa das habilitações deste nível de ensino, abolindo de vez a profissionalização antes ministrada em escola de nível ginasial. Assim a tradicional escola normal perdia o "status" de nível de escola e, mesmo, de curso, diluindo-se em uma das muitas habilitações profissionais do ensino de segundo grau, a chamada Habilitação Específica para o Magistério (HEM). 
O final dos anos de 1970 e início dos anos de 1980 juntamente com a crescente tentativa de criar movimentos de resistência diante da ditadura militar que cercear as liberdades em todos os setores da sociedade e na Educação, os debates sobre as estruturas e o funcionamento das escolas em geral e nos cursos profissionalizantes de magistério especificamente sofriam a influência deste contexto político com o objetivo de resistir e garantir formação autônoma para os professores.

É nesse contexto que o I Plano Setorial de Educação é pensado em São Paulo, no entanto, apenas no II Plano Setorial de Educação conforme afirma Cavalcante (1994) que se estabelece como objetivo geral a universalização da educação primária:

Esse plano estabeleceu como objetivo geral, para o ensino de $1^{\circ}$ grau, a universalização progressiva, definindo como meta, até 1980, a escolarização de $90 \%$ da faixa etária de 7 a 14 anos (CAVALCANTE, 1994, p. 52).

É a partir destas definições estabelecidas na política institucional que começa a implementação de um projeto de formação de professores, no sentido de revitalizar as Escolas Normais, para capacitar melhor o docente que executaria tal projeto.

Nos anos 1980, com a abertura política e a evidência do fim do governo militar, junto com os movimentos de resistência e reivindicações crescem também as discussões sobre os processos de redemocratização e os desdobramentos desses debates ajudam a compor os pilares para a construção da "nova escola brasileira".

É elaborado, então, segundo Tanuri (2000), o III Plano Setorial da Educação, que compreende o período de 1980 a 1985 e que mantêm o objetivo de valorização dos recursos humanos para o magistério, estabelecendo a Educação Básica como prioridade no processo de desenvolvimento da sociedade e contemplando, ainda, as áreas rurais e as periferias urbanas.

Tendo em vista as duras críticas à formação docente, o CENAFOR, em 1986, publica documento que sintetiza a crítica no período acerca das HEMs (TANURI, 2000, p. 22):

Dispersa no meio de tantas outras, a habilitação ao magistério assumiu caráter propedêutico e descaracterizou-se: se antes de 1971 o curso era acusado de hipertrofiar os aspectos instrumentais, em detrimento do conteúdo básico, geral e específico. O magistério continua entre as habilitações fracas em conteúdo científico, ao mesmo tempo que abriu mão de suas antigas exigências de seus aspectos instrumentais. A antiga 
sistemática do magistério primário em escolas normais foi destruída, e, em seu lugar, nasceu um padrão em quase tudo incompetente. A Habilitação para o Magistério não forma nem para aquilo que seria minimamente necessário ao professor da escola elementar: a capacidade de ensinar a ler, escrever e calcular.

Além destas críticas existia o debate sobre a dicotomização da formação docente, no que se referia à evidente separação entre teoria e prática, o conteúdo e o método, o núcleo comum e o profissionalizante, o desprestígio social do curso, a inadequação dos docentes. Entre essas críticas destacava-se, sobretudo, a ineficiência das aulas de estágio, que não oportunizam vivência de regência para o aluno-professor como expresso nas palavras de Tanuri (2000):

Aos problemas pertinentes a realização de Estágio de prática de ensino. A esse respeito, apesar de toda proclamação a respeito da função integradora da Prática de Ensino e das prescrições legais no sentido de que ela inclusive a observação, a participação e a regência, eram comuns as referências de que os estágios em geral se restringiam a observação e de que vinham sendo cumpridos apenas formalmente (TANURI, 2000, p. 82).

Após inúmeras reuniões entre técnicos do MEC, representantes das Secretarias de Educação dos Estados, bem como educadores, constrói-se um movimento em âmbito federal e estadual, com discussão de projetos, pesquisas e propostas de ação, frequentemente denominados de "revitalização do ensino normal" Tanuri (2000). Entre essas propostas destaca-se a referente ao projeto dos Centros de Formação e Aperfeiçoamento para o Magistério - CEFAM.

Para Tanuri (2000), o projeto criado em 1982 pela antiga Coordenadoria do Ensino Regular de Segundo Grau do MEC tinha por objetivo redimensionar as escolas normais, dotá-las de condições adequadas à formação de profissionais com competência técnica e política e ampliar as funções, de modo torná-las um centro de formação inicial e continuada para professores de educação pré-escolar e para o ensino das séries iniciais

Para os envolvidos neste projeto fica definido que os estados interessados em executar as propostas do MEC para uma alternativa aos cursos de magistério contariam com suporte técnico e financeiro. Os primeiros estados a declarar interesse e participar foram: Alagoas, Minas Gerais e Rio Grande do Sul. Devido à boa repercussão do projeto, logo foram seguidos pelos Estados da Bahia, Pernambuco e Piauí. E assim inicia o Projeto CEFAM em 06 estados brasileiros, com um total de 55 unidades. 
Em 1987, por intermédio do projeto de "Consolidação e Expansão dos CEFAMs" os Centros foram estendidos a mais nove estados: Santa Catarina, Mato Grosso, Mato Grosso do Sul, Sergipe, Paraíba, Rio Grande do Norte, Pará, Goiás e São Paulo, de modo a atingir 120 unidades em 1987, com 72.914 matrículas (Tanuri, 2000).

\section{A IMPLANTAÇÃO DO CEFAM NO ESTADO DE SÃO PAULO}

Em São Paulo a implantação do CEFAM assumiu características diferenciadas dos demais estados, pois o compromisso de criar orçamento destinado a remuneração dos estudantes por meio de bolsa de estudos no valor de 1 salário mínimo vigente deu ao projeto grande visibilidade e procura. Essa decisão caminhava na mesma direção de atender os estudantes das camadas populares e moradores das periferias urbanas e rurais, como (Moreira, 2008, p. 31) afirma em sua pesquisa:

Considerando que o ensino era integral e que os alunos eram, obrigatoriamente, $95 \%$ oriundos de escolas públicas a bolsa de estudos fez com que o Projeto assumisse grande visibilidade, além de garantir a permanência, em regime integral do aluno, possibilitando o aprofundamento teórico - prático e garantido os estágios.

O advento da bolsa de estudos elevou a procura a ponto de necessitar de realização de provas para seleção de ingresso. Essas provas também trouxeram os alunos com melhor preparo do ensino fundamental, colaborando assim com o projeto de formação de exigência elevada na rotina dos estudantes que também permaneciam na escola em período integral.

O decreto do Governo do Estado de São Paulo n. 28.089, de 13 de janeiro de 1988 expressa claramente os objetivos e finalidades na criação do CEFAM paulista.

Considerando-se:

A necessidade de recuperar a especificidade da formação do professor das séries iniciais do ensino de primeiro grau e da pré-escola;

A importância da Habilitação específica para o Magistério na formação integral do professor;

A necessidade de garantir a efetiva realização do estágio ao longo do curso de Habilitação para o Magistério;

A necessidade de se garantir a melhoria da qualidade do ensino através do aperfeiçoamento constante do pessoal docente;

Artigo $1^{\circ}$ - Ficam criados na rede estadual de ensino os Centros Específicos de Formação e Aperfeiçoamento para o Magistério com a finalidade de: 
I - Dar prioridade na efetiva formação dos professores da pré-escola até a $4^{\circ}$ série do $1^{\circ} \mathrm{Grau}$;

II - Aprimorar a formação dos professores que atuam na Habilitação Específica de $2^{\circ}$ Grau para o magistério e nas classes da pré-escola até a $4^{\circ}$ série do $1^{\circ}$ Grau.

Artigo $4^{\circ}$ - Serão concedidas bolsas de estudos a alunos do Centro na forma a ser regulamentada.

O CEFAM de São Paulo torna-se, assim, referência na formação de professores a partir do reconhecimento de sua experiência como bem sucedida, pela própria comunidade acadêmica.

Exemplo disso está na recomendação feita em documento do IV Congresso Estadual Paulista de Formação de Educadores, realizado em 1996, na cidade de Águas de São Pedro-SP, pelo Grupo de Trabalho de Formação de Educadores para séries iniciais. Nesse documento, no item que concerne à indicação de instituição para formar professores há a indicação explícita:

O grupo conclui que essa formação do professor reflexivo só ocorrerá em Centros de Formação Específicos que assegurem as condições já assinaladas. Assim propõe que, a partir da avaliação e discussão de experiências bem sucedidas, tanto no $2^{\circ}$ grau - CEFAM - quanto no $3^{\circ}$ grau - Pedagogia - os Centros incorporem os sucessos obtidos por essas experiências, ampliando-as (ÁGUAS DE SÃO PEDRO, IV CEPFE, p. 2).

Muito embora o CEFAM em São Paulo tenha obtido sucesso inquestionável, também sofreu críticas no que se referia à formação dos professores que atuavam nos Centros, bem como quanto ao acompanhamento e aproveitamento de egressos pela rede pública de ensino.

Ainda assim foram acrescentadas condições já reivindicadas há muito tempo pelos educadores, tais como: a presença de um coordenador pedagógico por unidade de CEFAM, o pagamento de horas de trabalho pedagógico e horas atividades aos professores, bem como maiores investimentos em recursos materiais e didáticos. Também a respeito do CEFAM de São Paulo, Gatti (2000) o define como sendo uma iniciativa de grande porte na direção de introduzir um diferencial nessa formação.

Os cursos oferecidos no CEFAM de São Paulo, mesmo possuindo lacunas e necessidade de melhorias demonstram que as avaliações procedidas sobre seu desempenho mostram muito mais aspectos positivos do que negativos. Nas palavras de Gatti (2000): “(...) É uma proposta que tem suas qualidades reafirmadas”. 


\section{CONSIDERAÇÕES FINAIS}

Ao revisitar a própria trajetória de formação e início da profissionalização alguns pontos coloco em destaque.

Os três primeiros estão na perspectiva do próprio percurso de vida.

- $\quad$ apoio familiar e o fato de encontrar bons professores no caminho foi essencial para escolha e permanência da escola de magistério e depois na universidade.

- $\quad \mathrm{O}$ encontro com amigos profissionais da educação que sempre foram generosos em bons conselhos sobre a carreira e os desafios enfrentados no cotidiano também se tornaram marcas importantes nesse processo.

- O CEFAM foi um divisor de história na minha vida, a possibilidade de estudar naquela escola, marcou todas as minhas escolhas de vida posteriormente. A carreira docente, foi para mim a única possibilidade de trabalho e cidadania. Foi a base para a construção sobre as escolhas políticas e ideológicas e foi o que me forjou como homem e profissional da Educação.

Os outros três pontos de destaque estão na perspectiva da ação do estado.

- A geração de professores formada no CEFAM é conhecidamente uma geração de bons profissionais. Além dos resultados da pesquisa de mestrado que realizei em 2008 no Programa de Estudos Pós Graduados em Educação: História, Política e Sociedade na PUC SP sobre a trajetória dos egressos do CEFAM, podemos afirmar que as memórias sobre esse modelo de escola são, sobretudo, de sucesso do modelo de formação.

- $\quad$ O estado é o principal indutor de políticas educacionais que transformam a vida de jovens. A manutenção de modelos de formação profissional com apoio integral para a permanência de jovens na escola é fundamental e transformador na história de vida da juventude.

- $\quad \mathrm{Na}$ área da educação, os concursos de ingresso e as condições de permanência da carreira, também são elementos essenciais para o atendimento da população e valorização dos profissionais. Foram por meio de concursos públicos que minha carreira na educação foi possível. Essa deve ser uma bandeira de permanente vigilância dos profissionais da educação e da sociedade. 
Na minha defesa de mestrado, a banca me perguntou sobre o que eu era ao terminar o curso de magistério no CEFAM.

Minha resposta foi: "Eu saí do CEFAM sem saber ser outra coisa, senão professor”. E assim tem sido desde lá.

\section{REFERÊNCIAS}

CAVALCANTE, M. J. A escola Normal caminhos e descaminhos, um novo itinerário. In: CEFAM: uma alternativa pedagógica para a formação do professor. São Paulo: Cortez, 1994.

DOCUMENTO FINAL do GT. Formação de Educadores para as séries iniciais. IV Congresso Estadual Paulista de Formação de Educadores. Águas de São Pedro. 1996.

GATTI, B. A. Formação de Professores e carreira: problemas e movimentos de renovação. Campinas, SP: Autores Associados, 2000.

MOREIRA, D. A Trajetória de formação e profissionalização dos egressos do CEFAM de São Miguel Paulista. Pesquisa de Mestrado. EHPS- PUC. 2008.

SÃO PAULO. ESTADO 1997. Lei Complementar nº 836/97. Dispõe sobre o plano de carreira docente.

SÃO PAULO. ESTADO 1988. Decreto $n^{\circ}$ 28.089. Dispõe sobre a criação dos Centros Específicos de Formação e Aperfeiçoamento para o Magistério.

SÃO PAULO. ESTADO 1988. Resolução da Secretaria Estadual de Educação. Nº14/88. Dispõe sobre a regulamentação para a instalação do CEFAM.

SÃO PAULO. ESTADO 1987. Parecer do Conselho Estadual de Educação n³0/87. Dispõe sobre a organização de pessoal e corpo docente para o CEFAMs.

SÃO PAULO. ESTADO 1988. Parecer do Conselho Estadual de Educação no 352/88. Dispõe sobre a articulação dos currículos de base comum e de formação específica para o magistério.

TANURI, L. história da formação de professores. Revista Brasileira de Educação, Rio de Janeiro/Campinas: ANPEd-UERJ/A. Associados, n.14, maio-agosto/2000, p.61-88. 


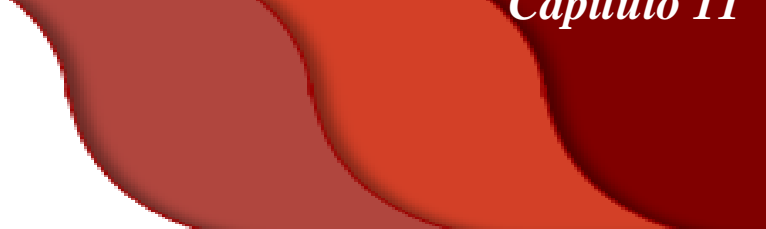

RELATO DE EXPERIÊNCIA NA PANDEMIA: A ATIVIDADE DOCENTE EM TEMPOS DE CORROSÃO DE DIREITOS E AMPLIAÇÃO DO TEMPO DE TRABALHO

REPORT OF EXPERIENCE IN THE PANDEMIC: TEACHING ACTIVITY IN TIMES OF CORROSION OF RIGHTS AND EXPANSION OF WORKING TIME

\section{RESUMO}

Neste artigo, buscou-se, por meio da observação e da reflexão sobre a prática, compartilhar experiências desenvolvidas durante a pandemia de Coronavírus (Sars-cov 19) no Ensino Médio do IFTM (Instituto Federal do Triângulo Mineiro).O objetivo central deste trabalho é discutir as condições do trabalho docente diante dos desafios impostos pela crise sanitária, como por exemplo o ensino remoto, a fim de que se possa, a partir da disseminação e aprofundamento deste debate, realizar novas reflexões tanto mais amplas, quanto sejam possíveis a respeito do estado de coisas da educação brasileira. Isto é, por meio do relato de experiência individual de um professor de ensino médio, pensar no presente e suas consequências a serem experimentadas num futuro que se aproxima, no que tange à educação e ao trabalho docente como práticas sociais e os limites impostos, seja pela pandemia, seja pela ordem do capitalismo tardio e as suas implicações.

Palavras-chave: Ensino médio. Pandemia. Ensino remoto. Trabalho docente. Relato experiência.

\section{INTRODUÇÃO}

No momento da produção deste artigo, o mundo se aproxima de dois anos de convivência com a pandemia do chamado novo Coronavírus (Sars-cov 19), também conhecido por Covid-19. Como se pode notar por meio das mais diversas fontes pesquisas, mídia, Organização das Nações Unidas (ONU) -, o enfrentamento à doença ocorreu de maneira muito desigual no mundo todo e, mais uma vez, os países mais ricos

${ }^{13}$ É doutor em Educação pelo programa de estudos pós-graduados em Educação: História, Política, Sociedade. Professor do Instituto Federal de Ciência e Tecnologia da Triângulo Mineiro - IFTM -, Campus Ituiutaba. 
do mundo tiveram as melhores condições de barrar o avanço da contaminação em massa; isto é, acesso às vacinas.

Mesmo antes da irrupção do recente fenômeno que afetou diretamente a educação, a saúde, a economia, enfim, a vida; ou seja, em cenário anterior à pandemia do novo Coronavírus, as expectativas sobre o futuro já pareciam um tanto modestas, no que se refere à plena recuperação econômica pós crise financeira dos anos 2008 e 2009. O centro do capitalismo mundial, principalmente a Europa ${ }^{14}$, ainda tateavam alguns posicionamentos sobre as expectativas de um futuro próximo, muito pouco otimistas.

Os desdobramentos da crise sanitária global são imensos e, certamente, afetam todos os eixos da vida, seja social, seja individual. Quando se pensa no sistema educacional no Brasil as coisas se barbarizam e revelam a face mais perversa da desigualdade social e seus efeitos.

Neste sentido, pensar sobre a realidade da educação no Brasil, não apenas durante a pandemia, implica refletir sobre a própria ação do sistema capitalista nas perspectivas do indivíduo e da sociedade.

No desenvolvimento deste trabalho, procurar-se-á evidenciar, por meio das experiências de docência, de observação e de reflexão, uma possibilidade de compreensão mais alargada do cotidiano escolar; tentando, dessa forma, ajudar a compreender tanto o que é ser, quanto qual é o papel do professor na contemporaneidade, sobretudo no Brasil.

\section{TRAJETÓRIA PESSOAL E DOCÊNCIA, CAMINHOS E PERCALÇOS ENTRELAÇADOS}

Venho de uma família, cuja primeira geração universitária é aquela que me antecede. De um lado, imigrantes alemães que se exilaram no Brasil por conta do trágico desenvolvimento da Alemanha nazista, de outro, agricultores, pessoas que tinham profundas raízes rurais e que tiravam seu sustento da terra.

\footnotetext{
${ }^{14}$ A principal publicação mundial, o porta voz, dos valores da forma econômica do capitalismo tardio (também chamado neoliberalismo), em outubro de 2019, advertia sobre a crise financeira que se avizinhava. Cf. < https://www.ft.com/content/987733a4-f316-11e9-b018-3ef8794b17c6>. Acesso em: 2 de Agosto de 2021.
} 
Com família fixada no interior de Minas Gerais, no Triângulo Mineiro, as condições de classe média, da qual provenho, permitiram-me percorrer a vida universitária.

Fixei residência na capital do estado de São Paulo, onde estive por quase 20 anos e desenvolvi toda a minha formação acadêmica, desde a graduação, até o doutoramento. Neste interim, iniciei meus estudos na Faculdade de Comunicação e Filosofia, Comfil, da Pontifícia Universidade Católica de São Paulo - PUC-SP - cursando Comunicação Social - Jornalismo.

A ideia que me norteara era a de um jovem idealista que, ao adentrar a universidade, cria na possibilidade de expansão de consciências por meio de um trabalho que demandaria tanto esforço, quanto honestidade, estamos falando do início dos anos 2000. Aos poucos, o mundo começava a ser desvelado ante aos meus olhos; à proporção que o curso se encaminhava para o seu encerramento, mais ainda me acercava da certeza de que, se não impossível, seria muito improvável que qualquer mudança significativa prosperasse num ambiente oligopolizado como a mídia brasileira.

A educação, desde o início de minha formação, sempre esteve no radar de minhas expectativas de aprofundamento e de melhor compreensão e sobretudo de acompanhamento e observação atentos; haja vista que o trabalho de conclusão de curso em Jornalismo foi um livro reportagem que buscava investigar as relações da cultura "hip-hop" com a educação em algumas cidades do estado paulista.

Em seguida, desta vez pela Universidade de São Paulo - USP, percorri o caminho da formação em Letras - português - inglês, licenciatura e bacharelado, momento em que se iniciaram as minhas primeiras experiências como professor, por volta do ano de 2009. No segundo semestre de 2011, início os estudos que deram origem à minha dissertação de mestrado e, na sequência, o doutoramento, finalizado em 2018.

Desde o momento em que comecei os estágios, nunca mais deixei a sala de aula, no entanto, as condições em que isso aconteceu, são bastante reveladoras do estado de coisas em que os professores estão inseridos. Até a conclusão do doutorado, passei pelas redes municipal, estadual e privada, na cidade de São Paulo, em todos os casos, em regimes sem registro profissional, seja na forma de contrato de prestação de serviços, na condição de professor estagiário, seja por meio de acordos verbais. 
No ano de 2019, sem sequer contratos, deixei a cidade de São Paulo e voltei para o interior de Minas Gerais, cidade de Ituiutaba, onde consegui colocação profissional, mais uma vez por meio de acordo verbal, na rede privada do município. No segundo semestre do mesmo ano, abriu-se um processo seletivo simplificado para professor substituto da rede federal de educação no Instituto Federal do Triângulo Mineiro IFTM - Campus Ituiutaba, em que permaneço.

O contrato temporário expirará em alguns meses, provavelmente no início do ano subsequente, 2022. Iniciada as atividades em 2020, com a pandemia, a instituição rapidamente transferiu as atividades para a forma remota, na qual permanecemos, já, há mais de um ano. Se este formato resolveu alguns problemas, no que se refere ao isolamento físico, trouxe muitos outros, para o cotidiano da docência, alguns dos quais procurar-se-á descrever em seguida.

\section{A PRÁTICA DOCENTE NA PANDEMIA}

Desde o início da minha carreira docente (trabalhei alguns anos como jornalista), o dia-a-dia escolar é sempre um desafio que nos traz reflexões, ansiedade, aprendizado, descobertas de novos meios de fazer, ao mesmo tempo, de realização pessoal.

No meu primeiro dia na condição de professor, senti a insegurança típica de quem inicia um caminho que desconhece, e também soube que aquele era o lugar em que eu sempre quis estar. Se havia alguma possibilidade de mudança, aspiradas desde a adolescência, parecia estar naquele momento diante de mim um caminho difícil, mas um caminho.

Ao racionalizar essas primeiras percepções, a vida profissional de professor ainda que achacada, vilipendiada, agredida, diminuída e menosprezada - ofertava a mim um novo olhar sobre a própria vida e sobre oportunidades e impossibilidades, caminhos e obstáculos a serem percorridos e desafiados, respectivamente.

Se isso foi uma constatação bastante imediata da prática, outras vieram com o tempo, por exemplo, a solidão docente. Descobre-se, paulatinamente, que a escola, cada vez mais está atravessada por uma série de exigências extraclasse que, o fazer do professor, torna-se, muitas vezes, uma atividade, se não irrefletida, pelo menos automatizada. Claro que, as condições organizacionais impõem estas circunstâncias, impossibilitando a conversa coletiva e a realização, efetiva, de reflexões e práticas do 
conjunto de professores, em qualquer perspectiva integradora que se queira pensar, a transdisciplinaridade, ou a interdisciplinaridade ${ }^{15}$.

Desde o início de 2020, ocupo o cargo de professor substituto de um Instituto Federal de Ciência e Tecnologia no interior de Minas Gerais, mais precisamente, na região do Triângulo Mineiro. Portanto, pensar em práticas integradoras é condição sine qua non para o pleno exercício da prática docente. Ou seja, se essa observação é fundamental para a realização de atividade profissional de qualquer professor, o é ainda mais nos casos em que se atua nas redes, cuja oferta é de ensino técnico integrado ao ensino médio.

O isolamento físico, imposto pela pandemia, trouxe consequências que, ainda hoje, experimentam-se em escolas de todo o Brasil, de todas as redes de ensino (municipal, estadual, federal e privada). A "solução" encontrada para diminuir os efeitos do afastamento físico, no que se refere tanto ao processo de socialização que as escolas ofertam, quanto ao atendimento de dificuldades e de acesso ao conteúdo de maneira geral, foi o estabelecimento do ensino remoto.

Evidentemente, com o prolongamento da pandemia, é fato que o ensino remoto diminuiu as perdas, no entanto, ao mesmo tempo, assumiu todas as consequências engendradas pelo grave quadro social da sociedade brasileira. Isto é, a inviabilidade, de uma grande parte dos alunos, de acompanhar, minimamente, as atividades remotas, seja por condições de pobreza e falta de acesso aos serviços de Internet, seja pela inobservância por parte das instituições escolares, de maneira geral, da realidade individual de cada aluno.

Ao estabelecer o ensino remoto como instrumento da prática de ensinoaprendizagem, colocou os demais problemas (organização familiar, condição financeira, autonomia individual de alunos do ensino médio e capacidade de concentração em seus respectivos ambientes residenciais) embaixo do tapete.

A realidade social que a supracitada rede federal me proporciona é a de perceber uma outra condição bastante diversa das grandes cidades, como São Paulo, por exemplo. Nesta região do país a principal atividade econômica é a agropecuária, daí, uma quantidade considerável de alunos residem na zona rural. Quer dizer, se as condições socioeconômicas já são um obstáculo ao acesso aos serviços de Internet, por exemplo; viver fora de zonas urbanas é uma barreira a mais, já que, na maior parte dos casos, o 
acesso à rede de computadores, se não impossível pelas condições de infraestrutura, são, obviamente, bastante mais caras. Esses e outros temas do cotidiano escolar serão mais bem desenvolvidos na sequência.

\section{A ATUAÇÃO dA PANDEMIA: DEMONSTRAÇÃO E APAGAMENTO DE CONTRADIÇÕES ESCOLARES}

A instituição escolar como um todo e a atividade educativa, em particular, é um processo constante de contradições, por meio do qual evidencia aquilo que reflete, a sociedade na qual está inserida. A prática demonstra claramente, no entanto, que não se trata de algo petrificado, estanque; ao contrário, a educação e as suas zonas de influência são, cada vez mais, objeto de observação e interferência cuidadosa e calculada dos entes que compõem a sociedade. Em outros termos, o "chão" da vida escolar é alvo de disputas de poder, de hegemonia, é um campo claro em que se manifesta a velha conhecida luta de classes.

Em estudos recentes, por meio de distintas abordagens Ferretti (2018), Kuenzer (2019), Leão (2018), Lima e Maciel (2018) e Silva (2018) apontam para os problemas do ensino médio, objeto de nosso interesse nesse relato, sobretudo após a Reforma do Ensino Médio de 16/02/2017, Lei 13.415. Conquanto haja abordagens distintas em cada um dos estudos citados, há uma preocupação em comum, analisar as possibilidades de perdas e ganhos nos pós reforma.

Pensando na própria palavra reforma, cujo significado poderia ser compreendido a partir da ideia de conferir nova forma, seria interessante lembrar a ideia de Adorno (2012) de que "forma é conteúdo sócio histórico decantado". Ao discutir as relações entre forma e conteúdo do romance moderno, o autor aponta para a conversão de ambos na mesma direção, ou seja, não é possível entender um aspecto, sem levar em conta o outro, intimamente associado ao primeiro.

Neste sentido, parece ser indispensável pensar como a nova forma do ensino médio, também é um novo conteúdo, conectado com as aspirações e propostas de governos, cuja orientação econômica, têm, sistematicamente, utilizado de recursos para sufocar a escola e suas práticas. Quer dizer, a reforma do ensino médio é apenas uma readequação, uma adaptação às condições impostas pela economia do capitalismo tardio, 
e isso se intensifica quando voltamos os olhos para a realidade brasileira, uma economia semiperiférica do capitalismo mundial.

A não compreensão adequada deste fenômeno e da própria posição do Brasil, implica, necessariamente, dificuldades na correta compreensão das práticas educacionais, muitas vezes, tidas como normais. Perceber a dinâmica das ações governamentais na escola, bem como as interferências do poder econômico na determinação de novas agendas, conteúdos e formas educacionais é condição sine qua non para avançar no diagnóstico, na conduta pessoal e coletiva, e porque não dizer, nas exigências de mudança. Localizar e lidar com as tensões é basilar para qualquer processo de alteração do que está posto.

Destarte, a pandemia desvelou novas e velhas tensões no interior das escolas, entre aquelas que parecem se perenizar na sociedade brasileira está a desigualdade social que, neste caso de ensino remoto, aparece nas condições de acesso à internet. Segundo pesquisa do PNAD (Pesquisa Nacional por Amostra de Domicílios), cerca de $21 \%$ da população brasileira sequer tem acesso à rede ${ }^{16}$. Mesmo assim, as redes de ensino, sobretudo as públicas, impuseram o ensino remoto como condição de atendimento aos alunos matriculados.

Não se trata da defesa desta ou daquela modalidade de ensino. As redes previram a entrega de matérias àqueles que, por alguma razão, não pudessem ter acesso às aulas virtuais. Entretanto, é necessário dizer que esse tipo de ação apenas reconhece passivamente as desigualdades, sem enfrentá-las efetivamente.

Diante da situação apresentada, não é difícil notar que, conquanto não se possa pensar nas melhores condições de ensino, aquilo que se oferta é feito de maneira desigual e deliberada, como se as perdas pudessem, num futuro incerto que nunca se presentifica, ser reparadas. Ocorre que a vida das famílias e dos alunos envolvidos em todo o processo educacional não tem volta atrás.

Desta maneira, todo o processo educacional revela estar embebido nas ideias e práticas já adiantadas pela própria reforma do ensino médio, isto é, a chamada meritocracia, em que o indivíduo que se esforça, ainda que tenha as piores condições materiais, tem as mesmas chances de alcançar "um lugar ao sol”, já que o sucesso ou o fracasso são de sua própria responsabilidade.

${ }^{16} \mathrm{Cf} .<$ https://agenciadenoticias.ibge.gov.br/agencia-sala-de-imprensa/2013-agencia-denoticias/releases/27515-pnad-continua-tic-2018-internet-chega-a-79-1-dos-domicilios-do-pais > 
Em outras palavras, o capitalismo tardio na sua forma atual, o neoliberalismo, apresenta, sem cerimônias a ideia de que a responsabilidade final é do indivíduo, transferindo assim os encargos do Estado para o indivíduo. Ao levar a cabo as práticas educacionais na modalidade remota, mesmo sabendo das diferentes condições de acesso de seus alunos, as redes em geral, e as escolas acedem à mesma postura.

Ao olhar o "ambiente escolar" (neste caso a moradia de professores, alunos e equipamentos eletrônicos), sem nenhuma ou com poucas interferências externas, entende-se a escola como uma ilha social, e não como algo que é expressão da própria sociedade. Sob esta percepção, a qualidade do ensino escolar tem relação muito mais próxima com a capacidade de gestão dos administradores, do que, propriamente, com as relações sociais e humanas estabelecidas no interior da própria instituição educacional. Neste sentido

a educação é isolada dos seus vínculos sociais e passa a ser vista como uma questão puramente de gestão. Imaginando "consertar" as escolas pela sua inserção no livre mercado e com propostas restritas às variáveis intraescolares, secundarizam a importância das variáveis extraescolares, entre elas o impacto das condições de vida das crianças na sua educação. Tal postura advém da recusa de levar em conta restrições estruturais no processo educativo e da concepção depreciativa que o neoliberalismo tem do serviço público e do magistério, que se expressa no desejo de "tornar o professor (e a escola) o único responsável" pela aprendizagem e uma vez tendo identificado "o responsável", promover políticas de "responsabilização verticalizadas" como forma de pressioná-lo (FREITAS, 2018, p. 37).

Se de um lado há a flagrante percepção de que há uma atitude deliberada que negligencia a importância da igualdade de condições no acesso à educação e, por extensão, a naturalização das desigualdades sociais, associado ao processo de responsabilização dos professores pelas condições da educação, por outro há um progressivo apagamento de relações sociais e econômicas que impingem, em grande medida, ao sistema educacional a atual circunstância de um abandono "justificado".

Obviamente, esse não é um processo que fora recém inaugurado, todavia, é necessário apontar a intensificação disso sob as novas condições que a reforma fez prosperar. Já não é nova a tentativa de desqualificar as conquistas populares, seja o sindicato, seja a universalização do acesso à saúde, seja a educação pública. Todos estes estão conectados a uma mesma lógica, a de garantir o avanço das privatizações, ora por 
meio de sindicatos patronais, ora pelos planos de saúde, ora pela ampliação da atuação dos setores privados na educação pública, tanto na forma de escolas próprias, quanto pelas orientações de composição do currículo escolar.

Quer dizer, a influência econômica da burguesia no planejamento educacional da educação pública avaliza o que deve e o que não pode ser ensinado aos estudantes da escola pública. Exemplo disso são os recentes movimentos em prol do que se convencionou chamar "Escola sem partido", defendendo a tese de que há doutrinação marxista nas escolas. Afirmações estas sem qualquer referência sólida na realidade concreta, uma vez que, sendo a escola um microcosmo da própria sociedade, a própria instituição escolar tende a abarcar todos os setores político-ideológicos que estão presentes na sociedade; ignorando o fato de que os professore não são uma classe trabalhadora homogênea.

O abandono justificado, sobre o qual falamos, se reflete, por exemplo, na adoção de cortes de verba pública para a educação ${ }^{17}$, tornando as condições, ainda mais precárias, cujo objetivo final é justificar a "incapacidade" do Estado e da classe trabalhadora de promover uma educação pública de qualidade; e, portanto, garantir apoio da opinião pública de que o melhor a fazer seria, primeiro uma gestão compartilhada com a iniciativa privada, que, a rigor, saberia lidar melhor com a educação. Na sequência, passar inteiramente (leia-se: privatizar) o sistema público de educação.

No final das contas, atendendo tanto à demanda dos setores privados gananciosos por ampliar sua lucratividade, como também à opinião pública, convencida de que a escola pública é, por natureza, ruim. Sobre isso temos:

Mas ainda não se esgotaram as contradições entre elas, pois empregar verbas públicas em entidades não públicas desconsidera se são associações democráticas e populares, ou se são iniciativas empresariais, que tentam tutelar as reivindicações democratizantes. Enquanto as primeiras contam com escassos recursos e lutam exatamente pelo acesso igualitário à educação pública, precisarão enfrentar as tentativas abertas ou discretas de solapar o princípio público, pois as segundas têm recursos com folga (inclusive através de isenções fiscais) e podem pretender definir qual deve ser a educação a ser 'prestada' às primeiras, inclusive desqualificando qualquer iniciativa de suas oponentes. Enquanto as primeiras lutam por seus direitos, as segundas jogam em

${ }^{17}$ Cf. $<$ https://www.redebrasilatual.com.br/educacao/2021/04/educacao-e-a-area-mais-atingida-peloscortes-orcamentarios-de-bolsonaro/ $>$ 
terreno com outras balizas: podem assegurar educação privada para seus filhos, podem vender educação em escolas privadas com apoio governamental e, acessoriamente, podem receber recursos para atuação filantrópica na educação pública. Mais inquietante: podem estabelecer um verdadeiro apartheid na educação: a pública seguiria destinadas aos 'outros', aos 'pobres', enquanto propõem outros tipos de educação, hierarquizados segundo o custo - e os destinatários - de cada escola (FONTES, 2018, p. 4).

Ao aderir ao ensino remoto, utilizando-se sobretudo de plataformas privadas, pouco ou nada se discutiu a respeito de a escola pública aderir a essa prática. Não se trata de posicionar-se contra, necessariamente, o que se pretende destacar é o fato da plena adaptação às circunstâncias impostas pela situação sanitária atual sem, pelo menos, realizar debates em torno da situação.

Apagando, mais uma vez, qualquer vestígio de interferência privada na educação pública; invisibilizando, outrossim, as disputas em torno das tarefas do ensino e demais consequências nas quais a própria rede de educação está inserida. Ou seja, as discussões em torno do bem público, sequer fazem aventar hipóteses de interpretação da realidade, menos ainda de resistência a ela.

Mais ainda, a instituição escolar é, em certa medida, o espírito do tempo em que se encontra, refletindo valores e costumes típicos de um determinado período histórico e suas relações de produção da vida. Pensar a forma da educação é pensar, simultaneamente, em seu conteúdo. Como se pode ver em:

\begin{abstract}
A burguesia aprendeu com a igreja como é possível, na escola, ensinar escravos. Mas seus filhos se formam nas escolas especiais, onde se formam proprietários da vida, pessoas que no futuro vão se beneficiar e desfrutar dos bens da vida. Nas escolas populares, aquelas escolas onde as crianças de operários e camponeses estudam, acontece a extinção sistemática do espírito. Aí ensinam-se crianças obedientes, servas do capital. Olhe para as escolas públicas na Alemanha, França, Suíça, etc., veja como lá reprimem nas crianças qualquer pensamento independente, como cravam em suas cabeças a moral burguesa, como ensinam a se inclinar perante a riqueza, perante qualquer comando, como ensinam a obedecer cegamente, a executar cada ordem do professor. A burguesia sabe perfeitamente que com a violência nua ela não poderá manter por muito tempo seu poder, ela faz o possível para promover a escravidão espiritual das massas (KRUPSKAYA, 2017, p. 82).
\end{abstract}

O excerto acima, originalmente publicado em 1921, demonstra como a história mudou e não mudou ao mesmo tempo. Transformou-se no sentido de precarizações 
ainda mais radicais da vida da classe trabalhadora, perda de direitos, desemprego massificado, concentração de riqueza, expansão tecnológica, etc., mas também permaneceu imóvel no que se refere à astúcia da atuação burguesa na educação das massas, futuros trabalhadores, ou, pelo menos, um cada vez mais numeroso exército de reserva para os postos de trabalho.

Se faz necessário, assim, não menoscabar as capacidades burguesas no sentido de fazer o que for para a manutenção de seus privilégios. As disputas e contradições são parte da sociedade e estão dentro do ambiente escolar. Cabe aos professores e trabalhadores da educação entender que essas disputas estão na ordem do dia, cotidianamente, inclusive os ardilosos métodos burgueses.

Ao reconhecer estas questões como fundamentais para o funcionamento da própria escola, lugar em que o pensamento deveria ter a sua morada garantida e salvaguardada, o que se percebe é justamente o seu oposto. As condições de desenvolvimento do trabalho pedagógico, ainda mais áridas durante a pandemia, isolou os professores e suas ações em ações individuais ou, quando muito, permitiu alguma aproximação entre pequenos grupos seccionados por área de interesse ou atuação.

Por isso mesmo, esforços foram redirecionados no sentido de que os professores pudessem estreitar contatos e desenvolver atividades conjuntas, tentativas que, quando possíveis, apenas possibilitou a realização de aproximações temporárias e pontuais. Nesse contexto a solidão docente tornou-se companheira de trabalho inseparável, revelando peremptoriamente a cisão social, evidenciada na elaboração e execução das práticas escolares.

Pouco espaço há para que haja conversas para pensar nas próprias condições de trabalho, ou, por exemplo, em ações coletivas e exigências de adequação institucional que garanta os recursos mínimos para o desempenho da função. Os professores, além do seu cotidiano de preparação de aulas e atividades, elaboração de planos de ensino, etc., agora também precisam produzir material a ser direcionado aos estudantes, já que eles não puderam retirar, sequer, o material de referência (didático) para acompanhar o desenvolvimento dos cursos.

Em outras palavras, o trabalho dos professores, em geral, e o meu, em particular, aumentou sobremaneira durante a pandemia e com consequências importantes que vão impactar os próximos anos, no que se refere ao desenvolvimento da educação. Ao aderir ao ensino remoto de modo irrefletido, apressado e sem os devidos cotejamentos com a 
realidade e o porvir, o pensamento e a análise circunstancial ganharam papéis coadjuvantes dentro do processo central de tomada de decisões para o presente e, por extensão, para o futuro. Sobre isso temos:

\begin{abstract}
O pensamento é sempre, automaticamente, um momento da vida total do indivíduo, que ora se desvanece, ora se reproduz, conforme a necessidade. Em contrapartida, num professor de escola, ou num escritor que jamais tenha saído de Berlim, cuja atividade se limite, por um lado, a um trabalho ingrato, por outro, aos prazeres do seu pensamento, cujo universo se estenda de Moabit a Kopenick e termine na porta de Hamburgo, como se uma parede o fechasse, cujas relações com este mundo estejam reduzidas ao mínimo pela situação material miserável, é sem dúvida inevitável que um indivíduo deste gênero que sente necessidade de pensar, o seu pensamento tome uma feição tão abstrata como ele mesmo e a sua própria existência; é inevitável que, face a um indivíduo assim indefeso, o pensamento se mova como forma anquilosada, como força cujo exercício oferece ao indivíduo a possibilidade de se evadir, por instantes, deste "mundo mau" que é o seu, a possibilidade de um prazer momentâneo (MARX; ENGELS, 1983, p. 29).
\end{abstract}

Assim como apontado no excerto, a dissensão entre trabalho duro e o tempo livre são antes de tudo, domínios do pensamento; impossível portanto, pensar na atualidade de um aspecto sem considerar o outro. São eles, também, produto das relações materiais vigentes em sociedade, e é o mesmo pensamento o agente capaz de ofertar totalidade aos processos da dinâmica social. Ante a estas observações é possível verificar que a paralisia do pensamento, ou seja, a sua incapacidade de apreender a realidade em movimento, conduz à ideia oposta, de que a separação dos elementos é o meio próprio da compreensão dos fenômenos.

No interior da escola que abriga o ensino técnico e propedêutico, caso dos Institutos Federais de Ciência e Tecnologia, as coisas se barbarizam, quando se pensa no divórcio artificial, mas vivo, que opera as relações entre as chamadas áreas técnicas e aqueloutras destinadas ao ensino da Base Nacional Comum Curricular (BNCC).

Conquanto haja a intenção de realizar a chamada integração entre as áreas técnica e propedêutica (também compreendida como cultura), presente nos documentos que organizam os cursos técnicos integrados ao ensino médio, a premissa que orienta a elaboração do documento é falsa. Isto porque para integrar algo, parte-se da ideia que são coisas distintas a serem colocadas num mesmo "caminho". Razão pela qual, de saída, os processos consequentes, cujas bases estão assentadas em projetos chamados integradores, estão fadados ao fracasso. 
A inexequibilidade dessas proposições deriva do fato da percepção incorreta a respeito da técnica, imaginando-a como algo externo e superior àquilo que é humano, todavia a técnica, a rigor, é resultado da própria divisão do trabalho social. Desta maneira, é claro que separar o ensino técnico do propedêutico é uma artificialidade imposta pelos processos de trabalho da sociedade capitalista. Sobre isso temos:

\begin{abstract}
Mas não devemos nos contentar em dividir nossa existência em uma metade racional, a da profissão, e outra isenta de responsabilidade, a do tempo livre. Parte do problema da relação entre técnica e cultura é seguramente o fato de os técnicos darem à cultura uma certa gravidade excessiva, não a consideram algo para se aliviar e, sobretudo, não se contentam com os artigos que a indústria cultural oferece e de que o cinema será apenas um modesto exemplo enquanto aguardamos a atrocidade da televisão. Conheci cientistas, engenheiros e organizadores industriais da mais alta habilidade que, em seu tempo livre, saciam sua sede de cultura nos livros de Löns ou Ganghofer. Acredito que estariam mais próximos da cultura se, em vez de mostrar preferência por substitutos de imitações do romantismo, tivessem se preocupado em determinar o lugar, o sentido e a finalidade do que fazem e do que não fazem. Na cultura de consumo dominante de hoje, há muitas coisas que merecem ser liquidadas e que a tecnologia teria todo o direito de liquidar. A exigência do humanismo não deve servir de desculpa para o molde e o atraso cultural. São precisamente pensadores e artistas progressistas que se destacaram da maneira mais enérgica daquela espuma cultural autoindulgente do passado e do presente com a qual somos alimentados, e muitas vezes - é o suficiente para me lembrar da Bauhaus - no nome da técnica. Os próprios técnicos não devem ficar atrás da vanguarda, que há muito invejam, mas sim colaborar com ela (ADORNO, 2010, p, 314-315 tradução livre feita pelo autor ${ }^{18}$ ).
\end{abstract}

Em outros termos, cultura e técnica (ensino propedêutico e ensino técnico) são concretizações das relações de produção de uma sociedade. Ainda que tenham funções

\footnotetext{
${ }^{18}$ Pero no deberíamos contentarnos con dividir nuestra existencia en una mitad racional, la de la profesión, y otra exenta de responsabilidad, la del tiempo libre. Parte del problema de la relación entre técnica y cultura es seguramente el hecho de que los técnicos confieren a la cultura cierta excesiva gravedad, no la consideran algo con que aliviarse, y sobre todo no se contentan con los artículos que la industria cultural nos proporciona y de los que el cine será sólo un modesto ejemplo mientras esperamos la atrocidad de la televisión. He conocido científicos, ingenieros y organizadores industriales de la mayor capacidad que en su tiempo libre apagan su sed de cultura en libros de Löns o Ganghofer. Creo que habrían estado más cerca de la cultura si en vez de mostrar preferencia por sucedáneos de un romanticismo venido a menos se hubiesen preocupado de determinar el lugar, el sentido y la finalidad de lo que hacen y lo que no hacen. En la cultura de consumo hoy dominante hay muchas cosas que merecen ser liquidadas y que la técnica tendría todo el derecho a liquidar. La exigencia del humanismo no debe servir de excusa al moho y a lo culturalmente atrasado. Precisamente los pensadores y artistas progresistas se han desprendido del modo más enérgico de esa espuma cultural autocomplaciente del pasado y del presente con que se nos alimenta, y bastantes veces -me basta recordar la Bauhaus - en nombre de la técnica. Los propios técnicos no deberían quedarse detrás de la vanguardia, a la que desde hace tiempo envidian, sino colaborar con ella (ADORNO, 2010, p, 314-315).
} 
diferentes, não são antagônicas como supõem, por exemplo, aqueles que entendem teoria e prática como elementos distintos. A crítica a essas percepções parecem ser a única saída para que se avance na compreensão deste fenômeno.

Os elementos sumariamente elencados neste tópico, buscam dar conta de tornar visíveis os momentos em que se evidenciam e ao mesmo tempo escondem durante a atual crise sanitária. Todavia não se deve entender essas informações como algo retirado de um contexto que pouco ou nada têm em comum com as práticas escolares cotidianas de tempos "normais". O objetivo é captar as continuidades e impermanências de um processo em andamento; isto é, a maior parte do que foi descrito, apenas ganhou maior relevo durante a pandemia.

\section{CONSIDERAÇÕES FINAIS}

A incapacidade de correta interpretação e enfrentamento das questões do dia-adia promovem, muitas vezes, uma postura vacilante diante dos desastres impostos pela ordem capitalista. Na chamada era das comunicações instantâneas, a capacidade de circulação de ideias e também de cultura atingiu uma escala jamais vista em toda história anterior. Mesmo assim, não tem sido possível evitar que a barbárie se espalhe, progressivamente, por todos os cantos do mundo.

Adorno (2011), já nos alertava sobre a necessidade de evitar que Auschwitz se repita, e advertia que a cultura não era elemento suficientemente capaz de evitar a barbárie, embora indispensável. $\mathrm{O}$ acesso à cultura de modo irrefletido pouco contribui na luta que se deve travar contra as estruturas monstruosas que estão sendo infligidas contra a maior parte da civilização sob o capitalismo tardio.

Os prognósticos são cada vez piores em relação ao porvir, e sem uma atitude esclarecida e organizada frente aos fatos que se apresentam cada dia mais terríveis, estamos pavimentando os trilhos do trem que nos levarão de volta à Auschwitz.

O fracasso da cultura de evitar a barbárie penetrou os muros da escola, que não consegue se desvencilhar do véu que lhe impede a visão clara sobre os artificialismos impingidos à prática docente. Parece ser um equívoco aguardar resoluções e leis extraordinárias que darão conta de solucionar as questões próprias da educação, especialmente no estado de coisas da contemporaneidade, que ao invés de propor um tipo de formação que possa se opor à contínua degradação das condições de vida na 
sociedade coeva, investe todo o seu poder decisório naquilo que reforça a subsunção das gerações futuras.

As proposições que giram em torno da aquisição de "competências" e "habilidades" já foram naturalizadas como algo necessário, muitas vezes sem se dar conta do valor semântico das palavras, cujas origens provém do mundo do trabalho. A propalada capacidade de tornar os alunos, futuras engrenagens da máquina capitalista, flexíveis é um elogio à adaptação plena à uma sociedade, cuja única promessa é a extinção, ainda mais aguda, dos direitos sociais que restam.

Nas disputas intraescolares da rede pública, a classe trabalhadora parece estar, sistematicamente, perdendo posições para pareceres que não aventam o atendimento de reivindicações por melhorias. $\mathrm{O}$ que permanece intocado é um pensamento empedernido amarrado à estante com prateleiras repletas de propostas empoeiradas, tanto quanto a própria ideia de reforma executada em 2017 no Brasil. Este pensamento, ao contrário, deve ser capaz de lidar com a dinâmica social e apreender seus significados. Se não formos cônscios e hábeis o suficiente para alterar o estado de coisas diante das reflexões urgentes sobre as práticas docentes, nada vai mudar. As alterações são aparentes e cumprem um objetivo claro; parafraseando as palavras de Lampedusa em "O leopardo", tudo deve se modificar, a fim de que nada efetivamente se transforme.

\section{REFERÊNCIAS}

ADORNO, T. Educação e Emancipação. Rio de Janeiro: Paz e Terra, 2011.

ADORNO, T. Notas de literatura I. São Paulo: Duas cidades; Editora 34, 2012.

ADORNO, T. Miscelánea I. Madrid, Espanha: Ediciones Akal, 2010.

FERRETTI, C. J. A reforma do Ensino Médio e sua questionável concepção de qualidade da educação. Estudos Avançados, 32(93), 25-42, 2018.

FREITAS, L. C. de. A reforma empresarial da educação: nova direita, velhas ideias. São Paulo: Expressão popular, 2018.

FONTES, V. Sociedade civil empresarial e a educação pública: qual democracia?, 2018. Disponível em: http://grupodetrabalhoeorientacao.com.br/Virginia_Fontes/artigos/Sociedade-civilempresarial-e-a-educacao-publica.pdf. Acesso em: 03 ago. 2021. 
KUENZER, A. Z. Sistema educacional e a formação de trabalhadores: a desqualificação do Ensino Médio Flexível. Ciência e Saúde Coletiva, 25(1), 2019.

KRUPSKAYA, N. A construção da pedagogia socialista: escritos selecionados. São Paulo: Expressão Popular, 2017.

LEÃO. G. O que os jovens podem esperar da reforma do ensino médio brasileiro?. Educação em Revista, Belo Horizonte, n. 34, 2018.

LIMA, M.; MACIEL, S. L. A reforma do Ensino Médio do governo Temer: corrosão do direito à educação no contexto de crise do capital no Brasil. Revista Brasileira de Educação, v. 23, 2018.

MARX, K.; ENGELS, F. Textos sobre Educação e Ensino. São Paulo: Editora Moraes LTDA, 1983.

SILVA, M. R. A BNCC da reforma do ensino médio: o resgate de um empoeirado discurso. Educação em Revista, Belo Horizonte, v. 34, 2018.

ZABALA, A. A prática educativa: Como ensinar. Porto Alegre: Artmed, 1998. 


\section{POSFÁCIO}

O campo epistêmico "prática pedagógica docente" tem sido objeto de muitos estudos, pesquisas e debates nas ciências da educação. A produção de conhecimento sobre o referido campo se constitui em um movimento importante principalmente por colaborar com importante conteúdo para a implementação de projetos e programas que venham evidenciar a importância dos professores e da educação pública no Brasil.

O livro online apresenta relatos de experiências de profissionais atuantes na oferta da educação básica de escolas públicas do Brasil. Atestamos que o manuscrito cumpre o seu objetivo que é dar voz a professores, diretores, coordenadores e pessoas que vivenciam cotidianamente a realidade da educação brasileira, ampliando as discussões acerca do trabalho na área educacional a partir das histórias da vida de profissionais da educação.

A escolha pelo relato de experiência enquanto opção metodológica que faz intersecção entre os capítulos representa a dimensão acadêmico sensível da organizadora e dos autores do manuscrito. Os relatos apontados apresentam performances de sujeitos em circunstância de práticas vividas em ricos contextos que verdadeiramente mereciam ser amplamente comunicados.

A valorização da prática territorializada impulsiona a importância dos resultados apontados nos capítulos, assim como, torna a leitura profundamente agradável, crítica, consistente e resistente. Ainda sobre a opção por relatos de experiências, é importante destacar que cada vez mais tal formato acadêmico têm sido cada vez mais utilizados nos mais diversos campos epistêmicos e dinâmicas formativas.

Os onze (11) capítulos que compõem o e-book "Com a palavra... Os profissionais da educação: relatos de experiência sobre o trabalho educacional" nos proporcionam um passeio imaginário incrível, ao mesmo tempo, criativo e revelador a partir da reflexão de temáticas que expressam a superação de um problema central da escola atual: a invisibilidade de experiências vividas pelos profissionais da educação a partir do silêncio sobre as suas histórias. Calar a revolução silenciosa que ocorre nas salas de aulas significa subestimar ou obstacularizar a oportunidade de difusão e de valorização de práticas transformadoras. Tais aspectos também se configuram como violência contra à escola pública. 
Diante do atual quadro da sociedade que avança aceleradamente nos campos das ciências e da tecnologia é urgente que a escola direcione as suas atividades para processos educativos em que a formação holística, humanizadora, crítica e solidária sejam os eixos condutores dos processos de ensino e de aprendizagem.

Os relatos de experiência revelam que é imprescindível uma formação integrada à realidade social a partir de mediações consistentes de conteúdo específicos a partir de movimentos cognitivos significativos possíveis a partir da didática e da prática educativa transformadora.

Revelam ainda que a escola deve ser um espaço de desenvolvimento humano aberto à vida de seres humanos e sociais. Lembram também que o modo como ocorrem as relações entre professores e alunos deve ser o mais afetuoso possível. A Pedagogia é ainda mais válida para o desenvolvimento humano quando apoia às necessidades dos aprendentes, seus sentimentos, suas aspirações e sonhos.

Após a leitura atenciosa dos capítulos do manuscrito, atestamos que as potentes reflexões sobre as práticas colaborarão com o desenvolvimento da postura profissional de trabalhadores da educação pública, uma vez que encoraja os leitores para irem além, exercitando, com autonomia, práticas reflexivas de intervenção integradora, que conduzem à melhoria dos processos de ensino e de aprendizagem.

Este manuscrito online, por um lado, privilegia a ampliação de espaços e tempos pedagógicos voltados para a aquisição de conceitos, procedimentos e atitudes, exaltando os princípios e fundamentos da educação básica transformadora e, por outro, problematiza saberes necessários às práxis, na sala de aula, como meio para conduzir à formação humana integral dos estudantes.

Concluímos com uma das mensagens mais fortes que se faz eminente no livro online: a escola é por excelência o lugar onde se processa o desenvolvimento humano a partir de intencionalidades político-pedagógicas. Os autores ao advogarem sobre isso realçam que é preciso superar as marcas da escola autoritária que impõe conhecimentos prontos e acabados direcionados para o receptor passivo que nada questiona ao ocupar a sala de aula. Sem dúvida, um manuscrito que inspira seus leitores para compreender a escola como lugar com potência de vida e de resistência por meio da garantia do desenvolvimento humano integral dos sujeitos.

Enfim, a partir dos assertivos argumentos dos autores dos capítulos e do brilhante plano de publicação delineado pelos organizadores, os leitores deste 
manuscrito passarão a entender mais profundamente sobre a interação entre teoria e prática nos contextos da escola pública de educação básica no Brasil.

Boa leitura!!! Andrezza Maria Batista do Nascimento Tavares 


\section{ÍNDICE REMISSIVO}

C

CEFAM

Corrosão de direitos e ampliação do tempo de trabalho

D

Desafio da profissão docente

$\mathbf{E}$

Ensino de língua inglesa

Educação especial

Educação inclusiva

Educação infantil

Ensino Remoto

Ensino Remoto e pandemia

Experiências profissionais e memórias

G

\section{Gestão escolar}

I

Início de carreira docente

$\mathbf{P}$

Pandemia

Pós graduação

Profissionais da educação

$\mathbf{R}$

Relatos de experiência

V

Vida Profissional docente

Violência escolar 


\section{AGRADECIMENTOS}

A todos os amigos que participaram e que contribuíram nesta obra.

Muito obrigada!

A professora Dra. Alda Junqueira Marin que aceitou escrever o prefácio desta obra.

Muito obrigada!

A todos os que diariamente ensinam.

Muito obrigada!

A todos que lutam por uma educação emancipada.

Muito obrigada!

A todos que lutam por uma educação inclusiva.

Muito obrigada!

Aos professores das escolas públicas.

Muito obrigada!

Aos professores que trabalham com formação de professores.

Muito obrigada!

Aos gestores e coordenadores que embasam seu trabalho na democracia.

Muito obrigada!

Por fim...

Aos profissionais da educação.

Muito obrigada! 


\section{ORGANIZADORA}

\section{FERNANDA OLIVEIRA COSTA GOMES}

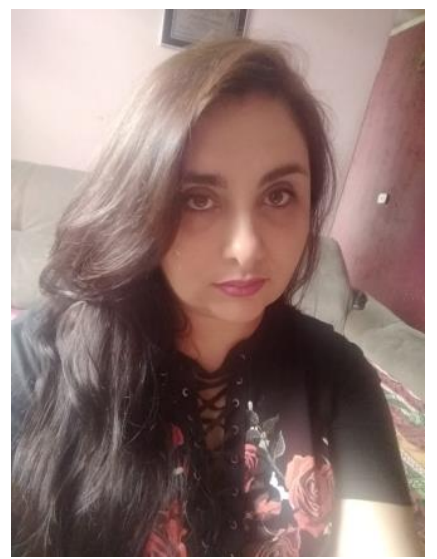

Doutora e Mestre em Educação: História, Política, Sociedade pela Pontifícia Universidade Católica. PUC/SP. Especialista em Psicopedagogia e Graduada em Pedagogia. Atua como professora do primeiro ciclo do ensino fundamental na rede municipal de educação da cidade de São Paulo. Tem experiência como docente no ensino superior em cursos de Pedagogia, Artes, Educação física nas disciplinas relacionadas à Didática, Metodologias de ensino, Metodologia de pesquisa, Sociologia, Psicologia e História da Educação. Pesquisadora na área de Didática e práticas de ensino tem centrado esforços nos estudos sobre o início de carreira docente. Currículo Lattes: http://lattes.cnpq.br/8044154037224066 


\section{AUTORES}

\section{ALINE MARTINS DE ALMEIDA}

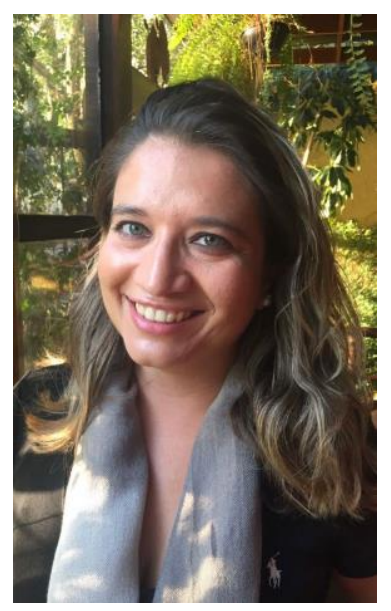

Doutora pelo Programa de Estudos Pós-Graduados em Educação: História, Política, Sociedade, da Pontifícia Universidade Católica de São Paulo, mestre pelo mesmo Programa e graduada em Pedagogia pela Pontifícia Universidade Católica de São Paulo. Estágio de doutorado-sanduíche na Universidade de Coimbra. Docente na Universidade Presbiteriana Mackenzie e Universidade Metropolitana de Santos.

Currículo Lattes: http://lattes.cnpq.br/9946250707768888 


\section{CRISTINA LEIKA HORII}

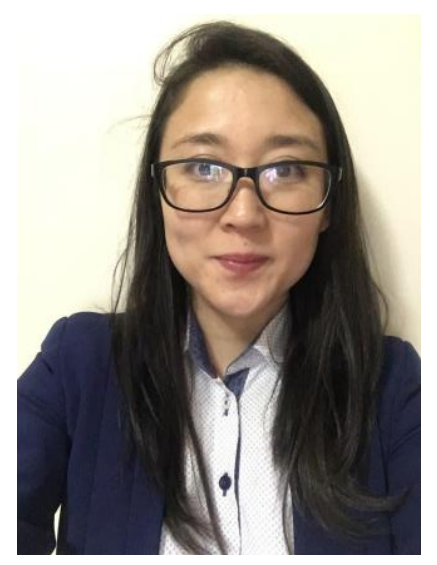

Licenciada em Física e Pedagogia pela Universidade de São Paulo. Mestre em ensino de Ciências pelo Programa de Pós-Graduação Interunidades da mesma universidade. Especialização em Educação em Saúde no Atendimento Escolar Hospitalar: Modalidade Residência pela UNIFESP/GRAACC. Com experiência docente em Hospital Oncológico Pediátrico, na Educação Infantil paulistana e agora como coordenadora pedagógica na mesma rede.

Currículo Lattes:http://lattes.cnpq.br/6007997197519291 


\section{DAVID BUDEUS FRANCO}

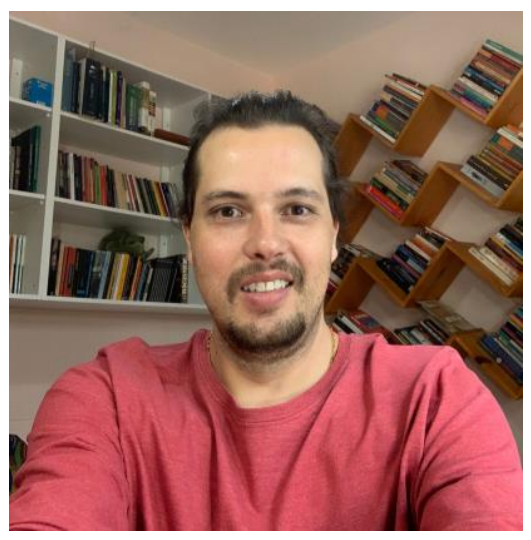

Doutor em Educação pelo programa de estudos pós-graduados em Educação: História, Política, Sociedade da PUC-SP (Pontifícia Universidade Católica de São Paulo); jornalista; bacharel e licenciado em Letras Português-Inglês; e licenciado em Pedagogia. Tem interesse nos temas: ensino médio, juventude, Teoria Crítica da Sociedade, experiência, formação cultural, entre outros. Atualmente é professor no IFTM (Instituto Federal do Triângulo Mineiro)

Currículo Lattes: http://lattes.cnpq.br/5592415543500329 


\section{DIEGO MOREIRA}

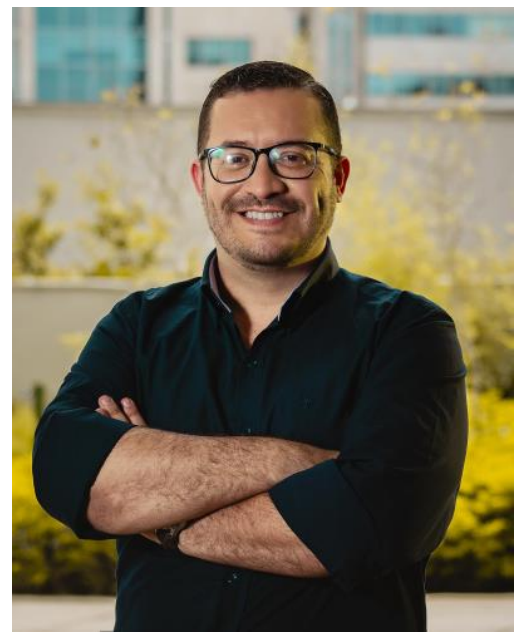

É doutorando e Mestre em Educação pela PUCSP. É graduado em História e Pedagogia. Há mais de 20 anos atua na carreira docente, com experiência desde o ensino fundamental até a Pós Graduação, em redes públicas e privadas. É pesquisador na área de formação de professores e Gestores. Leciona na Pós graduação nas áreas de Educação e Gestão de Pessoas. Coordenou cursos de Graduação e Pós Graduação em SP, também já foi analista do Instituto Unibanco. Apresenta o programa Educação em Pauta no grupo Cenário de Comunicação. Escreve semanalmente a coluna Educação em Pauta. Dirigiu o Instituto SEFAP de 2008 a 2017. Atualmente dirige a ESCOLA dos SABERES .É professor e apaixonado pela Educação.É um dos autores do livro BNCC na prática editado pela FTD Educação e da literatura infanto-juvenil Chicó, o corajoso. Currículo Lattes: http://lattes.cnpq.br/4947001348067694 


\section{ELAINE APARECIDA PEREIRA}

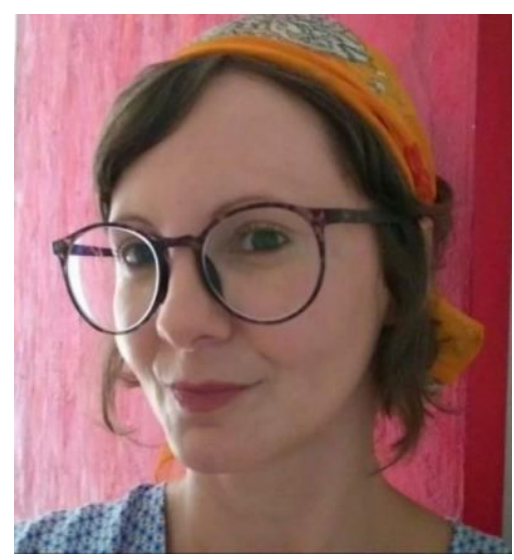

A autora possui doutorado e mestrado em Educação: História, Política, Sociedade (área de concentração Educação e Ciências Sociais) com pesquisas sobre o tema das relações escolares e graduação em História pela Pontifícia Universidade Católica de São Paulo. Graduou-se em Ciências Sociais, pela Fundação Santo André. Cursou licenciatura em Pedagogia na Universidade Cidade de São Paulo. Atua como professora de História na educação básica, desde 2003, tem experiência em gestão escolar e leciona no ensino superior na área das licenciaturas.

Currículo Lattes: http://lattes.cnpq.br/3147884772244425 


\section{HIGOR RIBEIRO DE ARAÚJO LIMA MACEDO}

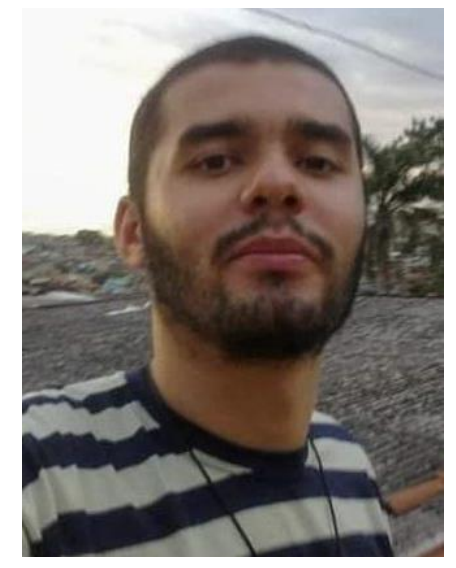

O autor é graduado em Letras - Português e Inglês pelo Centro Universitário de Jales UNIJALES (2018), graduação em Ciências Sociais pela Universidade Metropolitana de Santos - UNIMES (2015), graduação em Letras - Português e Espanhol pela Universidade Metodista de São Paulo - UMESP (2012) e graduação em Pedagogia pela Faculdade de Mauá - FAMA (2009), pós-graduação em Docência no Ensino Superior pela Faculdade de Conchas - FACON (2015), pós-graduação em Tecnologia Assistiva, Comunicação Alternativa e Língua Brasileira de Sinais - LIBRAS pelo Centro Universitário - UNISEB (2014), pós-graduação em Deficiência Intelectual pela Faculdade de Educação São Luis (2011), pós-graduação em Psicopedagogia Institucional pela Faculdade de Educação São Luis (2017), pós-graduação em Gestão Pública pela Faculdade de Educação São Luis (2017), pós-graduação em Educação Especial com ênfase em Transtornos Globais do Desenvolvimento e Altas Habilidades pela Faculdade São Luis (2018), pós-graduação em Educação Especial com ênfase em Deficiência Visual, Auditiva e Surdocegueira e pós-graduação em Neuropsicopedagogia pela Faculdade de Educação São Luis (2020). Trabalhou como professor de educação infantil pela Prefeitura de Mauá (2010-2012). Atualmente é professor de educação infantil e ensino fundamental I e ensino fundamental II e médio - Língua Portuguesa pela Prefeitura Municipal de São Paulo designado como Professor de Atendimento Educacional Especializado na Sala de Recursos Multifuncionais.

Currículo Lattes:: http://lattes.cnpq.br/6115834701535126 


\section{HUGO LEONARDO DE ALMEIDA}

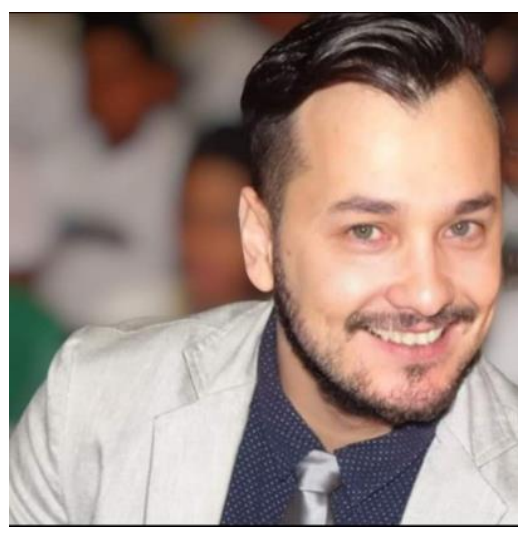

Licenciado em Pedagogia pela Faculdade de Mauá (2006), Licenciado em Letras pela Universidade Metropolitana de Santos (2016), Especialista em Letramento e Alfabetização pela Faculdade de Educação São Luís, Especialista em Psicopedagogia Institucional pelo Centro Universitário Barão de Mauá (2015), Especialista em Gestão da Educação Pública pela Universidade Federal de São Paulo-UNIFESP (2019) e Bacharelando em Teologia pelo Centro Universitário Internacional UNINTER. Exerceu a função de Diretor de Unidade Escolar da Prefeitura Municipal de Santo André no período de 2013 à 2016 e Professor Orientador de Informática Educativa da Prefeitura Municipal de São Paulo no período de 2014 à 2016. Atualmente é Professor de Educação Infantil e Ensino Fundamental I das prefeituras de Santo André e São Paulo. 


\section{IZOLDA MARIA BATISTA}

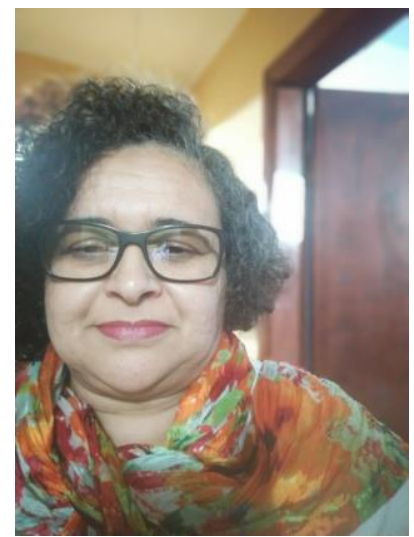

Possui graduação em Pedagogia pelo Centro Universitário Fundação Santo André (2003). Habilitação em Educação Especial e Orientação Pedagógica pela mesma faculdade. Especialização em Educação Infantil pela Universidade da Cidade de São Paulo - UNICID (2011). Pós-graduação em Educação Empreendedora pela Universidade Federal São João Del Rey- UFSJ (2011). Mestrado em Educação: História, Política, Sociedade pela Pontifícia Universidade Católica de São Paulo - PUCSP (2017). Doutoranda pelo Programa de Pós-graduação Educação: História, Política, Sociedade da PUC/SP. Iniciou a sua atuação na educação como professora de educação básica com classes de alfabetização na zona rural do Estado de Pernambuco, nos anos 1990. Atuou como Educadora na Incubadora de Cooperativas de Economia Solidária ITCPs 1998 a 2003. Educadora e Coordenadora Pedagógica no Centro de Educação, Estudos e Pesquisas -CEEP de 2001 a 2007. Foi Professora de Educação de Jovens e adultos EJA na Prefeitura Municipal de São Bernardo do Campo no ano de 2009. Ingresso na rede Municipal de São Paulo como Professora, durante estes trezes anos além da docência, assumiu por alguns períodos a Coordenação Pedagógica e na Direção.

Currículo Lattes:: http://lattes.cnpq.br/3038594955050677 


\section{LÚCIA MATIAS DA SILVA}

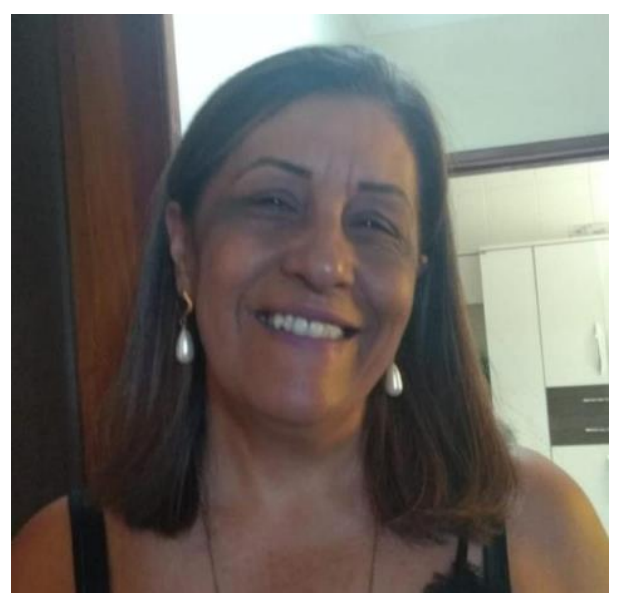

Licenciatura em Geografia e Pedagogia. Especialista em Gestão Escolar. Mestrado em Educação. Doutorado em Educação. Atua profissionalmente na Escola de Aplicação da Faculdade de Educação da Universidade de São Paulo - EAFEUSP. Faculdades Integradas Potencial - FIP Cotia

Currículo Lattes: http://lattes.cnpq.br/0082885885393683 


\section{MÁRCIA MARIA MARTINELLI}

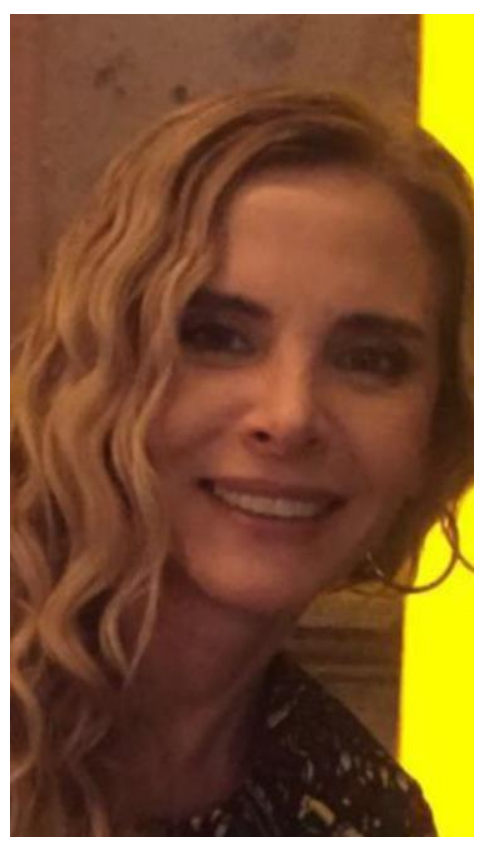

Licenciatura em Letras e Pedagogia - Mestrado em Linguística - Doutorado em Língua Portuguesa. Atua profissionalmente na Faculdades Integradas Potencial - FIP - Cotia.

Currículo Lattes: http://lattes.cnpq.br/2917707908199236 


\section{SANDRA MARIA SANCHES}

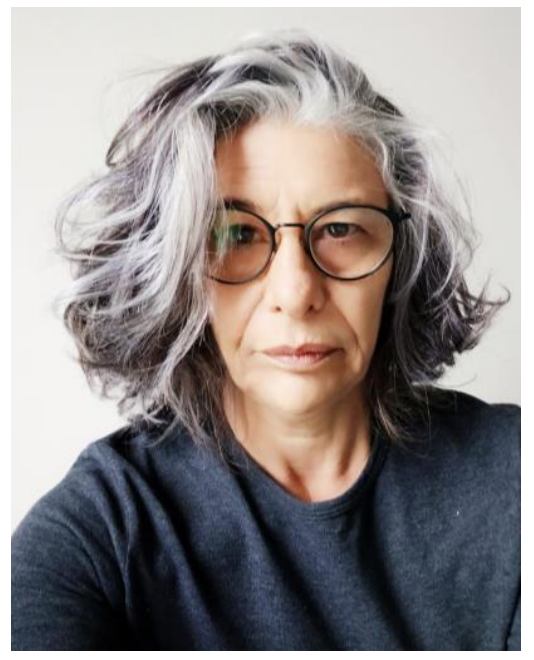

Doutora em Educação: História, Política, Sociedade / PUC-SP; Mestre pela Pontifícia Universidade Católica de São Paulo no PEPG Educação: História, Política, Sociedade (2014); Especialização: Fundamentos de uma educação para o pensar pela Pontifícia Universidade Católica de São Paulo (2009). Atualmente é diretora de escola da ESCOLA MUNICIPAL FERNANDO GRACIOSO. Tem experiência na área de Educação, com ênfase em Gestão. Faz parte do grupo de Pesquisa intitulado: Docência em suas múltiplas dimensões.

Currículo Lattes: http://lattes.cnpq.br/0831130857819509 
A Faculdade Metropolina Norte Riograndense (FAMEN) é credenciada pela Portaria no 665/MEC, publicada no Diário Oficial da União em 22 de março de 2019. Entre as atividades vinculadas ao ensino superior, a Faculdade oferece serviços acadêmicos da EDITORA FAMEN que objetiva a difusão de conhecimento por meio de e-books, periódicos (revista científica e jornal eletrônico), anais de eventos e repositório institucional, sendo vinculada à Diretoria de Pesquisa da Faculdade.

A EDITORA FAMEN é especializada em publicar conhecimentos relacionados ao campo da educação e a áreas afins por meio de plataforma online. $\mathrm{O}$ endereço eletrônico para acessar as suas publicações e demais serviços acadêmicos é $o$ www.editorafamen.com.br.

A EDITORA FAMEN realiza edição, difusão e distribuição de produções editoriais seguindo uma Política Editorial qualificada e baseada nas seguintes linhas: acadêmica, técnico-científica, produção didático-pedagógico, produção artístico-literária e cultura popular. 
O e-book intitulado "Com a palavra... Os profissionais da educação" tem por finalidade socializar experiências e histórias de vida na profissão docente. Esta coletânea apresenta mais do que uma série de artigos, mas contém histórias de vida repletas de desafios, percalços, superações, e também, discussões fundamentadas cientificamente, nos levando a perceber quão rico é o nosso lugar de labuta.

O trabalho dos profissionais da educação é certamente fonte de conhecimento, é um terreno repleto de "artefałos" a serem descobertos. São muitas as situações naturalizadas no ambiente das escolas, e que por serem naturalizadas passam despercebidas, mas o trabalho de um pesquisador é observar, procurar nas entrelinhas, e encontrar um objeto a ser estudado, debruçar-se sobre ele e compreendê-lo.

Essa é a função de um professor pesquisador, olhar bem para ver. Talvez pareça estranho ler isso, mas em muitas ocasiões olhamos e não vemos, não prestamos a devida atenção, e, uma oportunidade de pesquisa se perde. $\bigcirc$ exercício realizado neste trabalho consistiv em partir das nossas experiências, realizando uma discussão fundamentada na ciência, relacionando teoria e prática, buscando, portanto, saberes em nosso cotidiano.

Nosso objetivo foi disponibilizar um espaço para que aqueles que vivem o cotidiano da escola possam se manifestar. Nossa voz... nossa palavra é a nossa principal ferramenta de trabalho, e é também, nosso principal instrumento de luta. Pois, numa sociedade em que os profissionais da educação são constantemente atacados é preciso conhecer essas vozes, é preciso conhecer suas histórias. O trabalho educacional é complexo, e as condições de trabalho nada fáceis, e por isso registramos aqui algumas experiências, partindo do ponto de vista destes profissionais.

Esperamos que de alguma forma os textos apresentados possam contribuir com a área educacional, mesmo que modestamente. O presente livro virtual poderá ser acessado gratuitamente e democraticamente no site da ediłora FAMEN www.editorafamen.com.br.

Tenha uma ótima leitura!

Palavras-chave: Relatos de experiência. Vida profissional docente. Profissionais da Educação. Desafios contemporâneos na educação.

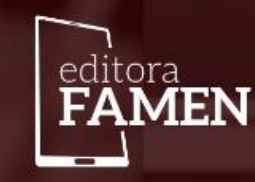

